


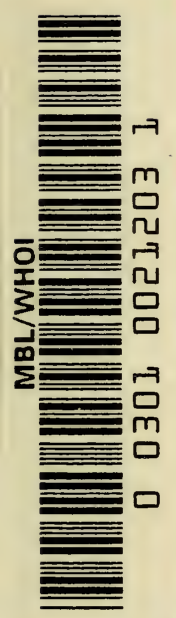




\section{LABORATORY MANUAL OF GENERAL MICROBIOLOGY}





\section{LABORATORY MANUAL OF \\ GENERAL MICROBIOLOGY}

WITH SPECIAL REFERENCE TO THE

MICROORGANISMS OF THE SOIL

BY

EDWIN BROUN FRED, Ph.D.

Professor of Agricultural Bacteriology, University of Wisconsin

AND

SELMAN A. WAKSMAN, Ph.D. Professor of Soil Microbiology, Rutgers University

First Edition SECOND Impression

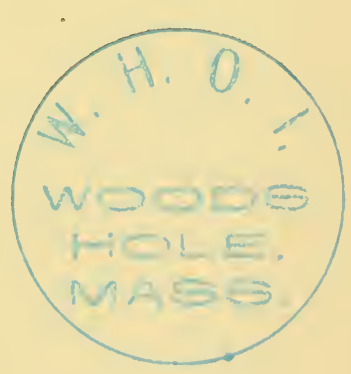

McGRAW-HILL BOOK COMPANY, INC. NEW YORK: 370 SEVENTH AVENUE

LONDON: 6 \& 8 BOUVERIE ST., E. C. 4 


\section{Copyright, 1928, BY The \\ McGraw-Hill Book Company, Inc. \\ PRINTED IN THE UNITED STATES OF AMERICA}




\section{PREFACE}

This laboratory manual has been designed for students in General Microbiology, and especially for those working with soils or with organisms isolated from the soil. Although various exercises are described primarily for students in soils, the methods of isolation and cultivation of bacteria, fungi, actinomyces, algæ and protozoa, and the determination of the biochemical activities of these organisms can be used by the student in General and Agricultural Microbiology. Special attention has been paid to the physiology of microorganisms, including the various so-called fermentation processes, in an attempt to bring out not only the qualitative but also the quantitative relationships of the various organisms.

It is assumed that the student has had previous training in general botany, zoology, bacteriology and chemistry; a knowledge of organic and physical chemistry, of mycology, and of protozoology will prove of great assistance in carrying out the experiments and in understanding the results.

Out of the numerous media suggested for the cultivation of non-pathogenic organisms, the authors selected the simplest, preferably the synthetic inorganic media, and those that have been found to be most useful. It is impossible to give all the chemical methods of analysis employed in microbiological investigations. Only a few of the most essential methods, dealing largely with the transformations of carbon and nitrogen, and to a less extent of phosphorus and sulphur, have been described.

In addition to references given in the text, frequent use has been made of the various manuals in bacteriology, a list of which is appended.

The authors are indebted to their associates for many helpful suggestions, especially to Dr. I. L. Baldwin, Miss Elizabeth McCoy, Dr. J. Blom, and Dr. R. L. Starkey.

MADison, Wis.

New Brunswick, N. J.

November, 1928.
Edwin Broun Fred.

Selman A. Waksman. 



\section{CONTENTS}

Preface. . . . . . . . . . . . . . . . . . . . .

\section{PART I \\ Culture Media}

Principles of Microbial Nutrition and Composition of Culture Media for Microorganisms. . . . . . . . . . . . . . . . 1

General Directions for the Preparation of Culture Media . . . . . 3

General Media for Isolation and Cultivation of Bacteria. . . . . . . 8

Media for Anaerobic Spore-forming Bacteria. . . . . . . . . . . . 11

Media for Fungi . . . . . . . . . . . . . . . . . . . . . 12

Media for Yeasts. . . . . . . . . . . . . . . . 16

Media for Actinomyces . . . . . . . . . . . . . . . . 18

Media for Protozoa. . . . . . . . . . . . . . . . 19

Media for Algæ. . . . . . . . . . . . . . . . . . 20

Media for Urea Bacteria. . . . . . . . . . . . . . 21

Media for Nitrifying Bacteria . . . . . . . . . . . . . . 22

Media for Nitrate-reducing and Denitrifying Bacteria. . . . . . . 25

Media for Reduction of Sulphates and Other Sulphur Compounds . . 26

Media for Sulphur-oxidizing Bacteria . . . . . . . . . . . 28

Media for Hydrogen and Methane Bacteria . . . . . . . . . . . 30

Media for Iron and Manganese Oxidizing Bacteria . . . . . . . . . 31

Media for Nitrogen-fixing Bacteria . . . . . . . . . . . . . . . . 32

Media for Cellulose-decomposing Bacteria . . . . . . . . . . 35

Special Media . . . . . . . . . . . . . . . . . . . . 39

Preserving Stock Cultures . . . . . . . . . . . . . . 45

Favorable Conditions for the Development of Anaerobic Bacteria. . . 46

$$
\begin{gathered}
\text { PART II } \\
\text { Methods of Staining }
\end{gathered}
$$

Methods of Staining Bacteria.

\section{PART III}

\section{Qualitative and Quantitative Methods of Analysis}

Preparation of Reagents. . . . . . . . . . . . . . 52

Preparation of Standard Solutions . . . . . . . . . . 54

Qualitative Methods for Determining Various Forms of Inorganic

Nitrogen. . . . . . . . . . . . . . . 56

Determination of Moisture in Soil. . . . . . . . . . . 61 
Moisture-holding Capacity of Soil. . . . . . . . . . . . 61

Quantitative Methods for Ammonia Determination. . . . . . . . . 62

Quantitative (Colorimetric) Methods for Determining Nitrates . . . 63

Quantitative Methods for Determining Total Nitrogen . . . . . . 65

Determination of Amino Nitrogen . . . . . . . . . . . . . . 69

Quantitative Determination of Carbohydrates . . . . . . . . . 69

Complete Analysis of Natural Organic Material. . . . . . . . . 76

Humus Determination. . . . . . . . . . . . . . . . 78

Carbon Dioxide Evolution. . . . . . . . . . . . . . . 79

Determination of Total Carbon. . . . . . . . . . . . . . 80

Seed Sterilization. . . . . . . . . . . . . . . . . 82

PART IV

The Study of Microorganisms in the Soll

A Suggested List of Arrangement of Class Exercises. . . . . . . . 87

Apparatus for One Student. . . . . . . . . . . . . . . 89

Laboratory Rules. . . . . . . . . . . . . . . . . . . . 89

A Black Finish for Table Tops. . . . . . . . . . . . . . . . . . 91

General Characteristics of the Soil Population . . . . . . . . . . . 92

Microscopic Examinations of Microorganisms . . . . . . . . . . . 95

Methods for Counting Numbers of Microorganisms. . . . . . . . . 97

Nitrogen-fixing Bacteria (and Nitrogen Fixation in Soil). . . . . . . 106

Denitrifying Bacteria . . . . . . . . . . . . . . 121

Nitrification . . . . . . . . . . . . . . . . . 123

Urea and Protein Decomposition . . . . . . . . . . . . . 126

Sulphate-reducing and Sulphur-oxidizing Bacteria. . . . . . . . 128

Iron Bacteria . . . . . . . . . . . . . . . . . . . . . . . . . . 132

Cellulose-decomposing Bacteria. . . . . . . . . . . . . . 133

Evolution of Carbon Dioxide from Soil . . . . . . . . . . . 136

Literature . . . . . . . . . . . . . . . . . . . . 137

List of Laboratories where Cultures Can Be Secured. . . . . . . . . 139

$\operatorname{INDEX}$. . . . . . . . . . . . . . . . . 141 


\section{LABORATORY MANUAL OF MICROBIOLOGY}

PART I

CULTURE MEDIA

PRINCIPLES OF MICROBIAL NUTRITION AND COMPOSITION OF CULTURE MEDIA FOR MICROORGANISMS

Since the work of Pasteur in the 'fifties and 'sixties of last century on pathogenic and non-pathogenic microbes and since 1881, when the first solid culture medium was suggested by $R$. Koch for the isolation and cultivation of bacteria, numerous solid, liquid, and semi-solid media have been recommended. The composition of these media depends entirely upon the food requirements of the specific organism that is to be isolated or cultivated. Since microorganisms vary in reference to the nature of the nutrients which they require for their growth and reproduction, the composition of the media which are to be used for the isolation and cultivation of different organisms will therefore vary. Some media are adapted to the growth of a maximum number of different organisms, not favoring any particular kind in preference to others. These are the media which are used for counting the numbers of microorganisms in the soil. Other media are highly selective in nature, allowing the development of only one very limited group of organisms. These selective or enrichment media are used largely for the isolation of certain specific organisms, utilizing their specific physiology.

In general, a medium must contain a source of energy, a source of carbon, a source of nitrogen, and various mineral elements 
(P, K, S, Ca, Mg, Fe, etc.), which are required by the organisms for the synthesis of their cell substance. Some organisms are very specific in the requirements of these nutrients, while others can derive their energy, their carbon, their nitrogen, and the mineral elements from a great variety of substances.

Microorganisms are divided broadly into two large groups, on the basis of their energy requirements: (1) The autotrophic organisms, which can obtain the energy required for their activities from the oxidation of inorganic elements or their compounds or from simple compounds of carbon, their carbon from carbon dioxide, and their nitrogen and other minerals from inorganic compounds. In addition to those organisms which can obtain their energy from the oxidation of inorganic substances or simple compounds of carbon (chemosynthetic), the chlorophyll-bearing plants, which obtain their energy photosynthetically are also classified with this group. (2) The heterotrophic organisms which obtain their energy and carbon from complex organic substances.

Among the heterotrophic organisms, however, there is also very considerable specificity. Some organisms can obtain their energy and carbon only from celluloses, while the great majority of microorganisms cannot attack celluloses and cannot utilize them either as sources of energy or of carbon. Some organisms can obtain their nitrogen from inorganic compounds, such as ammonium salts or nitrates; others require only organic nitrogen sources; still others can use even gaseous atmospheric nitrogen. Some can grow at a wide range of reactions; for the activities of others only a very limited range of hydrogen-ion concentration exists. Some organisms are able to grow on a great variety of media, liquid or solid; others will develop only on very specific media, when the particular nutrients are available.

In addition to the nature of the nutrients, it is also important to keep in mind that a specific osmotic pressure is required; in other words, the concentration of the nutrients must not vary within too wide limits. Solid media are often required; for this purpose either inorganic gels, largely silicic acid (also magnesium-gypsum blocks), or organic gels of a carbohydrate nature (agar-agar, etc.) or of a protein nature (gelatin, coagulated egg albumen, coagulated blood serum) are employed. 
These considerations can help one to realize why such a great variety of culture media have been proposed at various times and are used in microbiological studies. These media are frequently modified as regards the concentration of certain of the nutrients, reaction, buffer content, elimination of one nutrient and substitution of another.

\section{GENERAL DIRECTIONS FOR THE PREPARATION OF CULTURE MEDIA}

Of the numerous formulæ of various culture media, which have frequently been only briefly described, only the most essential and those which have been tried repeatedly and found useful are given in this manual. It is assumed that the reader has at hand a manual of general bacteriology, such as the Manual of Methods Prepared by the Society of American Bacteriologists; hence, all directions for the preparation of standards, for measuring the hydrogen-ion concentration, buffer content, etc. are omitted. The formulæ are arranged according to the general physiological characters of the microorganisms.

For general purposes, the reaction of culture media for bacteria should be about the neutral point, or $\mathrm{pH}$ 7.0. Some will grow at a considerably lower $\mathrm{pH}$ value, others will grow only at the neutral point or even at a more alkaline reaction. In some cases, bacteria can be separated from one another, by merely adjusting the reaction to such a point as to eliminate one group of organisms without injuring the other. Fungi are able, as a rule, to grow at a much higher acidity than bacteria. This fact is utilized frequently for the separation of these two groups of organisms: by adjusting the reaction of the medium to $\mathrm{pH} 4.0$, the bacteria are practically eliminated, while the great majority of fungi are not affected.

When it is necessary to adjust the reaction of a medium, the scheme outlined here will be found convenient. Place 2 cubic centimeters of the medium and 8 cubic centimeters of water in a test tube and add 4 or 5 drops of phenol red or any other of the desired indicators. Now add $0.1 \mathrm{~N}$ or $0.05 \mathrm{~N}$ sodium hydroxide from a burette until the color of the solution matches that of a known standard. Calculate and add to the medium the amount 
of normal sodium hydroxide required to make the reaction $\mathrm{pH}$ 7.0. Check the results by repeating titrations. All attempts to adjust the culture to an exact $\mathrm{pH}$ are unnecessary since the changes in reaction due to heat, glassware, etc., will be found greater than a $\mathrm{pH} 0.1$.

Filtration. Funnel Filter.-A cotton filter is prepared as follows: In the base of a large funnel place a small amount of clean excelsior. In place of the excelsior a small spiral of copper wire or iron-wire netting may be used. On top of this put two or three layers of absorbent cotton. Split a piece of absorbent cotton, somewhat larger than the top of the funnel, horizontally into two layers of equal thickness. Place one layer of cotton above the other, so that the fibers are at right angles and wash the cotton filter with boiling water. Pour the medium, slowly at first, on to the filter. (In order to avoid breaking the filter use a glass rod to direct the fluid to the center of the filter). When the filtrate begins to come through the cotton, fill the funnel. If the first filtrate is not clear, the turbid liquid should be refiltered through the same cotton.

If several liters of media are prepared the suction method given below will be found convenient.

Suction Filter.-Prepare an absorbent cotton filter on the top of a heavy walled glass bottle; milk bottles are satisfactory. Place a layer of cheesecloth on the top of the bottle, then one or two layers of absorbent cotton and cover with another layer of cheesecloth. Be sure that the filter is tied tightly around the neck of the bottle. Now invert bottle in a saucepan containing the medium. It is sometimes necessary to use a weight to hold down the empty bottle. Place in the autoclave and heat to 10 or 15 pounds pressure for 20 minutes. Allow to cool slowly. The heat will exhaust the bottles and as it cools the medium is drawn up through the filter pads. Since the vacuum in the bottles is never complete, the bottles are usually found to be about two-thirds full after filtration.

Solid Media.-For the preparation of solid media, agar, gelatin, or silica gel are commonly employed. Some of the differences between these substances are shown in the following table: 
General Properties

\begin{tabular}{|c|c|c|c|}
\hline & Agar & Gelatin & Silica gel \\
\hline 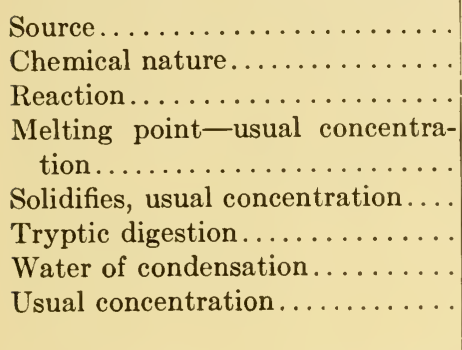 & $\begin{array}{l}\text { Plant } \\
\text { Carbohydrate } \\
\text { Faintly acid } \\
96^{\circ} \mathrm{C} \text {. } \\
40^{\circ} \mathrm{C} \text {. } \\
\text { Not affected } \\
\text { Present } \\
1 \text { to } 1 \frac{1}{2} \text { per } \\
\text { cent }\end{array}$ & $\begin{array}{l}\text { Animal } \\
\text { Protein } \\
\text { Acid } \\
25^{\circ} \mathrm{C} \text {. } \\
25^{\circ} \mathrm{C} \text {. } \\
\text { Liquefied } \\
\text { None } \\
10 \text { to } 12 \\
\text { per cent }\end{array}$ & $\begin{array}{l}\text { Inorganic } \\
\text { Silicic acid } \\
\text { Acid }\end{array}$ \\
\hline
\end{tabular}

Agar-agar is prepared by extracting certain seaweeds (largely Gelidium corneum) with hot water. It consists almost entirely of polysaccharides (largely galactans with some pentosan ${ }^{1}$ ) and a small admixture of protein and mineral matter.

\section{Approximate Chemical Composition of Agar and Gelatin}

$$
\begin{array}{cc}
\text { Agar, } & 2 \\
\text { Per Cent } & \text { Per Cent }
\end{array}
$$

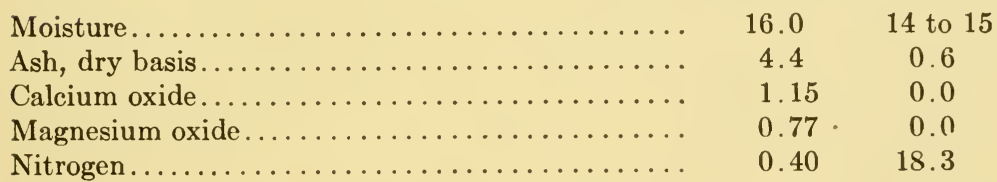

Pure agar has practically no buffer effect within the range commonly employed.

Washed Agar.-This is prepared as follows: Take 1,000 grams of agar shreds, place in an enamel pail or glass vessel with 10 liters of distilled water and allow to stand for 24 hours at room temperature. Place a piece of cheesecloth over the top of the vessel, pour off the water and once more add fresh distilled water and allow to soak another 24 hours. Now pour off the water, and allow the agar to air dry in thin layers.

Agar treated in this way is much lower in calcium and magnesium, as well as in soluble organic matter. In the preparation

${ }^{1}$ KöNig and Betrels, Ztschr. Unters. Nahr. u. Genussm., 10: 487, 1905.

${ }^{2}$ Fellers, C. R., J. Ind. Eng. Chem., 8: 1128, 1916. 
of certain kinds of culture media, it has been found that the removal of these inorganic salts prevents the formation of a precipitate during sterilization and hence gives a clearer medium.

Preparation of Silica Gel.-Prepare a 25 per cent solution of equal parts of sodium and potassium silicate (C.P.). Adjust the specific gravity of the solution to 1.06 . Five cubic centimeters of this solution is then poured into a Petri dish, and a drop of phenolphthalein added. An approximately 5 per cent solution of $\mathrm{HCl}$ is added to this silicate, from a graduated pipette, until the color is just discharged. The acid is then adjusted so that 5 cubic centimeters of $\mathrm{HCl}$ solution will just neutralize 5 cubic centimeters of the silicate. If care is taken not to overrun the acid, the gel will set in a few minutes.

To make the Petri plates, add a definite volume of the silicate. solution to an equivalent amount of acid, placed in a large flask. Shake the mixture vigorously and immediately pour 20- to 50cubic centimeter portions into Petri dishes. Allow the plates to harden upon a flat surface. They are then placed in deep flat vessels and dialyzed in running tap water until free from chlorides. About 24 hours is required for this purpose. The dishes are then removed and transferred to a sterile vessel containing boiled distilled water. This is replaced several times. After they have been properly washed, the dishes are drained and treated with the nutrient medium.

Sterilization.-Unless otherwise stated, it is recommended that all media be sterilized in the autoclave. In the case of liquid and agar media, about $120^{\circ} \mathrm{C}$. for 20 minutes will be found sufficient for complete destruction of all microorganisms. In sterilization, it must be remembered that the time required to kill bacteria depends upon the degree of heat at the center of the vessel and the nature of the medium. This degree of heat is determined by the size of the container, the original temperature and viscosity of the contents, and also by the free access of the steam to the surface of the container. All sterilizers should be equipped with temperature controls and with air outlets at the bottom. To secure the best results, place the mediun in small containers and space in the autoclave in such a way as to give free access of the steam to the surfaces. The time of sterilization must be determined for the various types of media. Agar 
media are best sterilized at 15 pounds pressure for 15 to 30 minutes. Gelatin media are sterilized in flowing steam on three consecutive days or in the autoclave at 10 pounds pressure for 30 minutes. Soil is extremely difficult to sterilize. Small containers with about 5 to 10 grams of soil are heated in the autoclave at 15 to 20 pounds pressure for 2 hours one day, or 1 hour on each of 2 consecutive days, or in flowing steam on at least 7 consecutive days.

The relation between pressure and temperature is shown in the table below:

\begin{tabular}{c|c|c}
\hline \multirow{2}{*}{ Temperature } & \multicolumn{2}{|c}{ Pressure } \\
\cline { 2 - 3 } & $\begin{array}{c}\text { Pounds per } \\
\text { square inch }\end{array}$ & Atmosphere \\
& 0 & 0 \\
$100^{\circ} \mathrm{C} \ldots \ldots \ldots \ldots$ & 7.5 & 0.5 \\
$112^{\circ} \mathrm{C} \ldots \ldots \ldots \ldots$ & 15.0 & 1.0 \\
$121^{\circ} \mathrm{C} \ldots \ldots \ldots \ldots$ & 22.5 & 1.5 \\
$128^{\circ} \mathrm{C} \ldots \ldots \ldots \ldots \ldots$ & 30.0 & 2.0 \\
$135^{\circ} \mathrm{C} \ldots \ldots \ldots \ldots$
\end{tabular}

The reaction of a medium has a decided influence upon the decompositions brought about by sterilization. The lower the $\mathrm{pH}$ of the medium, the greater will be the hydrolyzing effect of the sterilization, not only of gelatin, but also of agar, so that at $\mathrm{pH} 4.0$, as much as 3 per cent agar has to be used to obtain a solid medium. When the medium is alkaline, the iron of the solution will be precipitated out. This may necessitate the addition of a small amount of sterile iron salt, or the sterilization of the medium by filtration through a Berkefeld filter.

It is recommended that culture media be inoculated as soon as possible after sterilization. Because of the adsorbed air, old culture medium is unfit for the growth of strict anaerobic bacteria.

Silica gel media need not be sterilized. The washing with sterilc ter, followed by the use of highly selective media is sufficient to assure sterility, as far as air contaminations are concerned. Their use is adapted only to the very selective organisms. 


\section{GENERAL MEDIA FOR ISOLATION AND CULTIVATION OF BACTERIA}

\section{Medium 1}

Nutrient Broth or Bouillon

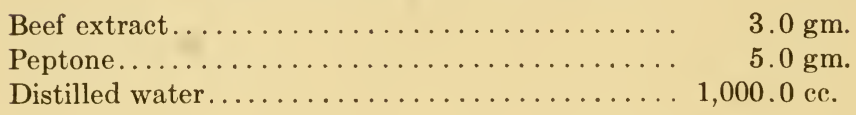

Heat until extract and peptone are dissolved.

Adjust reaction to $\mathrm{pH} 6.6$ to 7.0 using Brom thymol blue.

\section{Medium 2}

Nutrient or Beef-extract Agar

The same composition as nutrient broth (Medium 1) plus 15 grams of agar.

\section{Medium 3}

\section{Nutrient or Beef-extract Gelatin}

Gelatin.................... 100.0 to $150.0 \mathrm{gm}$.

Beef extract................... $\quad 3.0 \mathrm{gm}$.

Peptone.................... $5.0 \mathrm{gm}$.

Distilled water................ $\quad 1,000.0 \mathrm{cc}$.

In a convenient vessel measure 1,000 cubic centimeters of nutrient broth.

Add 10 to 15 per cent gelatin. Let the gelatin soak 5 to 10 minutes.

Heat over water bath until dissolved.

Adjust the reaction as directed in the preparation of nutrient broth. Gelatin is decidedly acid and has a high buffer value; it will, therefore, require more $\mathrm{NaOH}$ for neutralization than bouillon or agar.

If properly prepared, gelatin may be filtered through filter paper. Otherwise it will be necessary to use an absorbentcotton filter. 
Medium 4

Sodium Caseinate or Nutrose Agar

\begin{tabular}{|c|c|}
\hline & 12 \\
\hline caseinate (nutrose) & $2.0 \mathrm{gr}$ \\
\hline luco & $1.0 \mathrm{~g}$ \\
\hline sium phosphate $\left(\mathrm{K}_{2} \mathrm{HPO}_{4}\right)$. & 0.2 \\
\hline lagnesium sulphate $\left(\mathrm{MgSO}_{4} \cdot 7 \mathrm{H}_{2} \mathrm{O}\right) \ldots \ldots$ & $\begin{array}{l}0.2 \mathrm{~g} \\
\text { trace }\end{array}$ \\
\hline
\end{tabular}

Tap water........................ 1,000.0 ce.

Reaction approximately $\mathrm{pH} 6.8$.

It is not necessary to adjust the reaction of this medium. To secure a clear agar filter through cotton.

\section{Medium 5 \\ Sodium Albuminate Agar ${ }^{1}$}

Agar................................

$12.5 \mathrm{gm}$.

Glucose..................... $1.0 \mathrm{gm}$.

Dipotassium phosphate $\left(\mathrm{K}_{2} \mathrm{HPO}_{4}\right) \ldots \ldots \ldots \ldots .0 .5 \mathrm{gm}$.

Magnesium sulphate $\left(\mathrm{MgSO}_{4} \cdot 7 \mathrm{H}_{2} \mathrm{O}\right) \ldots \ldots \ldots .0 .2 \mathrm{gm}$.

Ferric sulphate $\left(\mathrm{Fe}_{2}\left(\mathrm{SO}_{4}\right)_{3} \cdot 9 \mathrm{H}_{2} \mathrm{O}\right) \ldots \ldots \ldots \ldots$ trace

Egg albumen (powdered) ............. $0.25 \mathrm{gm}$.

Water, distilled................. 1,000.0 cc.

${ }^{1}$ Waksman, S. A., Soil Sci., 14 : 283-298, 1922.

Make a suspension of the egg albumen in a little water (5 cubic centimeters), add a drop of phenolphthalein and enough $0.1 N \mathrm{NaOH}$ to dissolve and bring solution to a permanent pink color; the sodium albuminate is then added to the remainder of the medium. Reaction is about $\mathrm{pH} 7.2$.

\section{Medium 6}

Nährstoff-HĘYden AgaR ${ }^{2}$

Agar........................ $12.5 \mathrm{gm}$.

Nährstoff-Heyden................ $7.5 \mathrm{gm}$.

Distilled water................... $1,000.0 \mathrm{cc}$.

${ }^{2}$ Hesse, W., and Niedner, Z. Hyg., 29 : 454-462, 1898.

To 500 cubic centimeters of cold distilled water in a flask add 7.5 grams of Nährstoff-Heyden. Shake until a good suspension is obtained and allow the mixture to stand for 30 minutes or more. 
Heat in steamer or double boiler for 1 hour, or until the upper portion of the solution is clear.

While hot filter through paper.

Dissolve 12.5 grams of agar in 500 cubic centimeters of water. Filter and mix the Nährstoff-Heyden and agar solutions.

It is not necessary to adjust the reaction of this medium.

\section{Medium 7}

Soll-eXtract Agar

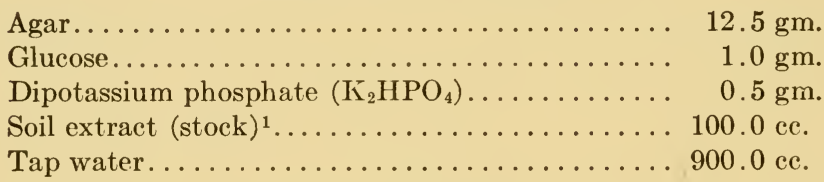

${ }^{1}$ Stock Solution of Soil Extract.-This is prepared by heating 1,000 grams of garden soil with 1,000 cubic centimeters of tap water in the autoclave for 30 minutes. A small amount of calcium carbonate is added and the whole is filtered through a double paper filter. The turbid filtrate should be poured back on to the filter until it comes through clear.

Dissolve the agar in 900 cubic centimeters of water by heating in the steamer for 1 hour or longer. Add 100 cubic centimeters of the stock soil-extract solution.

Add the glucose just prior to tubing.

The reaction should be $\mathrm{pH} 6.8$.

\section{Medium 8}

\section{Soll-extract Gelatin ${ }^{2}$}

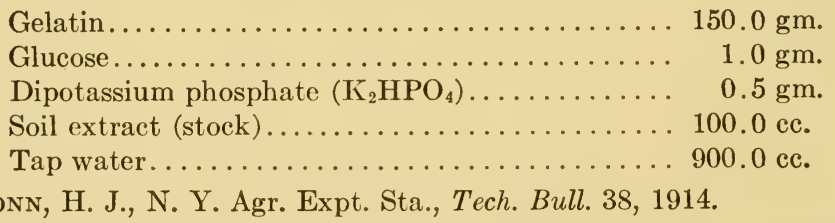

Dissolve the gelatin in the diluted soil-extract solution by heating slowly in the steamer.

Clarify the medium with egg albumen.

Add 1 gram of glucose and adjust the reaction to $\mathrm{pH} 6.8$.

To prevent the spread of liquefying colonies add 5 grams of sodium chloride $(\mathrm{NaCl})$ per liter. 
Medium 9

Asparagin Mannitol Agar ${ }^{1}$

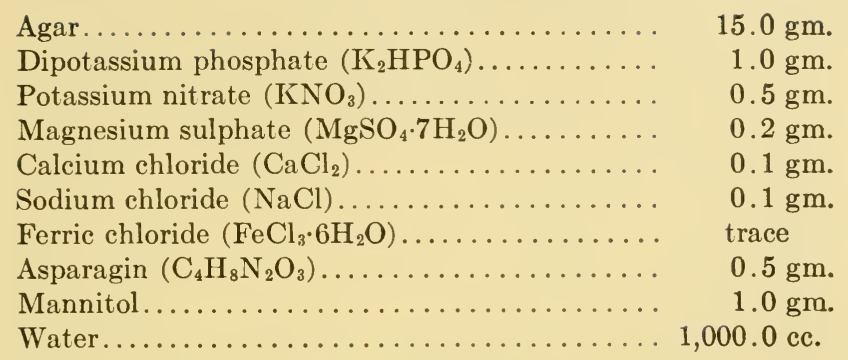

${ }_{1}^{1}$ Thornton, H. G., Ann. Appl. Biol., 9: 241-274, 1922.

After the agar and salts have been dissolved add the mannitol, adjust the reaction to $\mathrm{pH} 7.4$ (Brom thymol blue) and filter. Mannitol is recommended in place of glucose or related sugars because it decomposes less than the common sugars during sterilization.

\section{Medium 10}

TAP-water Gelatin ${ }^{2}$

Gelatin...................... 120 to $200.0 \mathrm{gm}$.

Tap water................... 1,000.0 ce.

${ }^{2}$ Conn, H. J., N. Y. Agr. Expt. Sta., Tech. Bull. 57, 1917.

Reaction $\mathrm{pH} 6.5$.

Incubate the plates at $18^{\circ} \mathrm{C}$. for 7 days. This medium is especially useful in qualitative studies of soil flora.

\section{MEDIA FOR ANAEROBIC SPORE-FORMING BACTERIA}

\section{Medium 11}

Glucose-phosphate Nitrogen Free Medium for Anaerobic Bacteria ${ }^{3}$

Dipotassium phosphate $\left(\mathrm{K}_{2} \mathrm{HPO}_{4}\right) \ldots \ldots \ldots \ldots . \quad 1.0 \mathrm{gm}$.

Magnesium sulphate $\left(\mathrm{MgSO}_{4} \cdot 7 \mathrm{H}_{2} \mathrm{O}\right) \ldots \ldots \ldots \ldots, 0.2 \mathrm{gm}$.

Sodium chloride $(\mathrm{NaCl}) \ldots \ldots \ldots \ldots \ldots \ldots \ldots .0 .01 \mathrm{gm}$.

Ferrous sulphate $\left(\mathrm{FeSO}_{4} \cdot 7 \mathrm{H}_{2} \mathrm{O}\right) \ldots \ldots \ldots \ldots \ldots, 0.01 \mathrm{gm}$.

Manganese sulphate $\left(\mathrm{MnSO}_{4} \cdot 4 \mathrm{H}_{2} \mathrm{O}\right) \ldots \ldots \ldots \ldots, 0.01 \mathrm{gm}$.

Glucose....................... $20.0 \mathrm{gm}$.

Calcium carbonate $\left(\mathrm{CaCO}_{3}\right) \ldots \ldots \ldots \ldots \ldots, 30.0 \mathrm{gm}$.

Distilled water.................... 1,000.0 cc.

${ }^{3}$ Winogradsky, S., Centr. Bakt., II Abt., 9: 49, 1902. 
In order to prevent decomposition of the glucose, it is well to sterilize the calcium carbonate separately. Tube in deep layers. For a solid medium add $\mathbf{1 5}$ grams of agar to each liter.

\section{Medium 12}

Winogradsky's Glucose-Peptone Agar

Agar......................... $15.0 \mathrm{gm}$.

Peptone.................... $5.0 \mathrm{gm}$.

Beef extract................... $\quad 3.0 \mathrm{gm}$.

Glucose..................... $5.0 \mathrm{gm}$.

Tap water....................... 1,000.0 ce.

Reaction, $\mathrm{pH}$ 7.0. Deep tubes.

\section{Medium 13}

Peptone-mannitol Solution for Anaerobic Bacteria ${ }^{1}$

Peptone...................... $2.5 \mathrm{gm}$.

Beef extract................... $2.0 \mathrm{gm}$.

Mannitol or glucose............... $10.0 \mathrm{gm}$.

Manganese sulphate $\left(\mathrm{MnSO}_{4} \cdot 4 \mathrm{H}_{2} \mathrm{O}\right) \ldots \ldots \ldots, 0.004 \mathrm{gm}$.

Tap water..................... 1,000.0 ce.

${ }^{1}$ Truffaut, G. et N. Bezssonoff, Compt. rend. Acad. Sci., 173 : 868, 1921.

Adjust the reaction to $\mathrm{pH} 7.0$.

\section{MEDIA FOR FUNGI}

\section{Medium 14}

\section{RadLin's Solution}

Ammonium nitrate $\left(\mathrm{NH}_{4} \mathrm{NO}_{3}\right) \ldots \ldots \ldots \ldots$

$4.0 \mathrm{gm}$.

Ammonium phosphate $\left(\left(\mathrm{NH}_{4}\right)_{2} \mathrm{HPO}_{4}\right) \ldots \ldots$.

$0.6 \mathrm{gm}$.

Ammonium sulphate $\left(\left(\mathrm{NH}_{4}\right)_{2} \mathrm{SO}_{4}\right) \ldots \ldots \ldots \ldots$.

Potassium carbonate $\left(\mathrm{K}_{2} \mathrm{CO}_{3}\right) \ldots \ldots \ldots \ldots \ldots$

$0.25 \mathrm{gm}$.

Magnesium carbonate $\left(\mathrm{MgCO}_{3}\right) \ldots \ldots \ldots \ldots$

$0.6 \mathrm{gm}$.

Zine sulphate $\left(\mathrm{ZnSO}_{4}\right) \ldots \ldots \ldots \ldots \ldots \ldots$

Ferrous sulphate $\left(\mathrm{FeSO}_{4} \cdot 7 \mathrm{H}_{2} \mathrm{O}\right) \ldots \ldots \ldots \ldots$.

$0.4 \mathrm{gm}$.

$0.07 \mathrm{gm}$.

$0.07 \mathrm{gm}$.

Potassium silicate $\left(\mathrm{K}_{2} \mathrm{SiO}_{3}\right) \ldots \ldots \ldots \ldots \ldots . \quad 0.07 \mathrm{gm}$.

Tartaric acid......................... $4.0 \mathrm{gm}$.

Sucrose........................ $70.0 \mathrm{gm}$.

Distilled water.................. 1,500.0 cc.

This medium is given here due to its historical significance. The cultivation of fungi can be carried out successfully on a much simpler medium. 
Medium 15

Ammonidm Nitrate-sucrose Solution

Ammonium nitrate $\left(\mathrm{NH}_{4} \mathrm{NO}_{3}\right) \ldots \ldots \ldots \ldots \ldots . \quad 3.0 \mathrm{gm}$.

Monopotassium phosphate $\left(\mathrm{KH}_{2} \mathrm{PO}_{4}\right) \ldots \ldots \ldots . \quad 1.0 \mathrm{gm}$.

Magnesium sulphate $\left(\mathrm{MgSO}_{4} \cdot 7 \mathrm{H}_{2} \mathrm{O}\right) \ldots \ldots \ldots \ldots . \quad 1.0 \mathrm{gm}$.

Ferrous sulphate $\left(\mathrm{FeSO}_{4} \cdot 7 \mathrm{H}_{2} \mathrm{O}\right) \ldots \ldots \ldots \ldots$ trace

Sucrose...................... $50.0 \mathrm{gm}$.

Distilled water.................... 1,000.0 cc.

\section{Medium 16}

Sodium Nitrate-sucrose Solution (Czapek's) ${ }^{1}$

Sodium nitrate $\left(\mathrm{NaNO}_{3}\right) \ldots \ldots \ldots \ldots \ldots \ldots .2 .0 \quad \mathrm{gm}$.

Monopotassium phosphate $\left(\mathrm{KH}_{2} \mathrm{PO}_{4}\right) \ldots \ldots \ldots . \quad 1.00 \mathrm{gm}$.

Potassium chloride $(\mathrm{KCl}) \ldots \ldots \ldots \ldots \ldots \ldots . \quad 0.50 \mathrm{gm}$.

Magnesium sulphate $\left(\mathrm{MgSO}_{4} \cdot 7 \mathrm{H}_{2} \mathrm{O}\right) \ldots \ldots \ldots .0 .50 \mathrm{gm}$.

Ferrous sulphate $\left(\mathrm{FeSO}_{4} \cdot 7 \mathrm{H}_{2} \mathrm{O} \ldots \ldots \ldots \ldots \ldots, 0.01 \mathrm{gm}\right.$.

Sucrose ..................... $\quad 30.00 \mathrm{gm}$.

Distilled water................... 1,000.00 cc.

${ }^{1}$ Czapek, F., Beiträge z. chem. Physiol. u. Path., I : 538-560, 1901.

To prepare an agar medium, add 15 grams of agar to 1,000 cubic centimeters of solution. Dissolve and filter. The reaction is left unadjusted.

\section{Medium 17}

Asparagin-glucose Agar ${ }^{1}$

Agar......................... $15.0 \mathrm{gm}$.

Glucose...................... $10.0 \mathrm{gm}$.

Asparagin.................... $0.5 \mathrm{gm}$.

Dipotassium phosphate $\left(\mathrm{K}_{2} \mathrm{HPO}_{4}\right) \ldots \ldots \ldots \ldots, 0.5 \mathrm{gm}$.

Distilled water.................... 1,000.0 cc.

${ }^{1}$ Krainsky, A., Centr. Bakt. II Abt., 41: 649-688, 1914.

This medium is also used for the cultivation of actinomyces.

\section{Medium 18}

\section{Peptone-glucosie Agid AgaR ${ }^{1}$}

Agar

Monopotassium phosphate $\left(\mathrm{KH}_{2} \mathrm{PO}_{4}\right) \ldots \ldots \ldots$.

Magnesium sulphate $\left(\mathrm{MgSO}_{4} \cdot 7 \mathrm{H}_{2} \mathrm{O}\right) \ldots \ldots \ldots$.

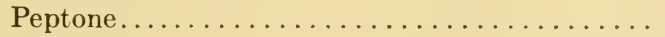

Glucose........................ $10.0 \mathrm{gm}$.

Water.......................... 1,000.0 ec.

${ }^{1}$ Waksman, S. A., J. Bact., $7:$ 339-341, 1922.

Reaction pH 3.8 to 4.0 . 
Dissolve the salts, peptone and agar by steaming for $1 / 2$ to 1 hour, adjust the reaction to $\mathrm{pH} 3.8$ to 4.0 with $N / 1 \mathrm{H}_{2} \mathrm{SO}_{4}$ (about 5 to 7 cubic centimeters of $N / 1$ per liter) and then add the glucose. Filter through cotton, using a suction flask. Because of the acid reaction sterilize in the autoclave at $110^{\circ} \mathrm{C}$. ( 7 to 8 pounds pressure) not more than 10 minutes. Avoid excessive heat.

The medium may be prepared without addition of acid, filtered, then placed in 100-cubic centimeter portions, in Erlenmeyer flasks and sterilized. Whenever needed for use, the agar is melted by placing flasks in boiling water. One cubic centimeter of $\mathrm{N} / 2 \mathrm{H}_{2} \mathrm{SO}_{4}$ is then added to each flask giving the desired reaction.

\section{Medium 19}

\section{Potato-glucose Agar}

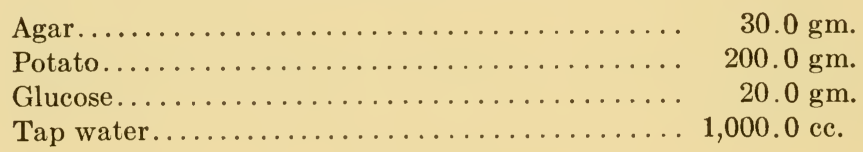

Peel and slice 200 grams of potatoes. Cook in 1,000 cubic centimeters water for 1 hour in the steamer. Strain or decant the clear liquid and restore it to the original volume. Add 20 grams glucose and 30 grams agar. Heat in steamer until the agar is dissolved. Filter through cotton filter.

\section{Medium 20}

\section{Asparagin-starch Agar ${ }^{1}$}

(Brown, modified for color formation)

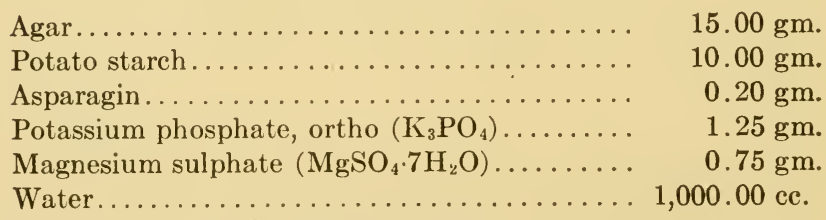

${ }^{1}$ Brown, W., Ann. Bot., 39 : 405, 1925. 
Medium 21

Clover-sucrose Agar
Agar
$25.0 \mathrm{gm}$.
Clover (green tops)
$500.0 \mathrm{gm}$.
Sucrose
$2.0 \mathrm{gm}$.
Potassium nitrate $\left(\mathrm{KNO}_{3}\right)$
$0.5 \mathrm{gm}$.
Tap water $1,000.0 \mathrm{cc}$.

Extract the clover tissue by heating for 1 hour in the steamer; filter and add the other ingredients. Add 1 to 2 drops of concentrated lactic acid to each tube of the medium just before pouring plates.

Reaction approximately $\mathrm{pH} 3.5$.

\section{Medium 22}

\section{Peptone-Malt Agar ${ }^{1}$}

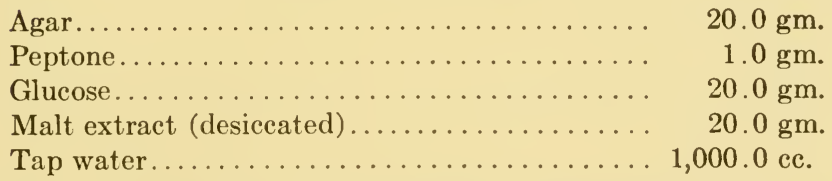

${ }^{1}$ Povah, A. H. W., Torrey Bot. Club. Bull., 44 : 241, 287, 1917.

This medium is used for the cultivation of Mucorales.

\section{Medium 23}

\section{Ammonium Nitrate Lactic Acid Solotion²}

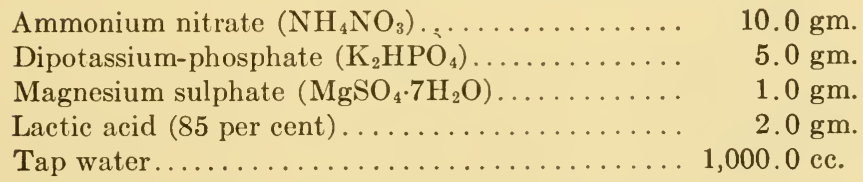

${ }^{2}$ v. Tubeur, C., Centr. Bakt., II Abt., 9: 127-135, 1902.

Fifty-cubic centimeter portions of this solution are added to flasks containing 10 grams of filter paper. This medium is used for the cultivation of wood-destroying fungi. 


\section{MEDIA FOR YEASTS}

\section{Medium 24}

Sucrose Peptone (Hansen's) Solution

Sucrose or maltose...................

$50.0 \mathrm{gm}$.

Peptone

$10.0 \mathrm{gm}$.

Monopotassium phosphate $\left(\mathrm{KH}_{2} \mathrm{PO}_{4}\right)$

$3.0 \mathrm{gm}$.

Magnesium sulphate $\left(\mathrm{MgSO}_{4} \cdot 7 \mathrm{H}_{2} \mathrm{O}\right)$

2.0 to $5.0 \mathrm{gm}$.

Distilled water.................... $1,000.0$ ce.

\section{Medium 25}

\section{Sucrose-Malt Extract Agar}

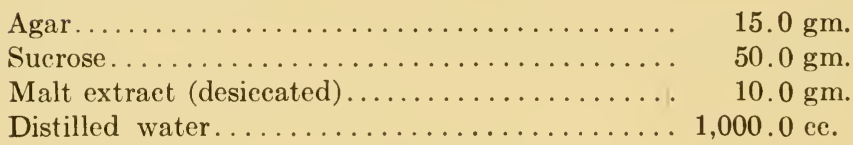

\section{Medium 26}

MaLt Extract Broth

Malt (finely ground) $\ldots \ldots \ldots \ldots \ldots \ldots \ldots \ldots, 250.0 \mathrm{gm}$.

or

Malt extract (desiceated).............. $15.0 \mathrm{gm}$.

Water......................... 1,000.0 ce.

Incubate for 1 hour at $65^{\circ} \mathrm{C}$. and test for starch; when the latter is still present, incubate for a longer time. Filter through a hand press, cook for 2 to 3 hours. Again filter and make up to 1 liter. For a solid medium add 1.2 to 1.5 per cent of agar.

\section{Medium 27}

\section{Fresh Yeast Infusion}

Yeast (fresh-pressed eakes, stareh-free) ....... $100.0 \mathrm{gm}$.

Water........................... 1,000.0 ee.

The 1-pound cake of starch-free pressed yeast will be found useful. Steam for 3 to 4 hours with occasional stirring. Sterilize in deep layers and allow to stand for 1 week. If undisturbed the yeast cells will settle to the bottom and leave a clear strawcolored liquid above. This clear infusion should be siphoned off and the reaction adjusted to $\mathrm{pH} 6.6$ to 6.8 . Yeast extract prepared in this way contains only a trace of fermentable carbo- 
hydrates, a small amount of non-volatile acid, and about 50 milligrams of nitrogen in 100 cubic centimeters. For fermentation studies, add 1 to 2 per cent of the required carbohydrate. For a solid medium add 15 grams of agar.

\section{Medium 28}

\section{Dried Yeast Infusion}

Yeast (dry, starch-free) .............. $10.0 \mathrm{gm}$.

Water........................ 1,000.0 cc.

Proceed as described under medium 27.

\section{Medium 29}

Dried Yeast-peptone Infusion

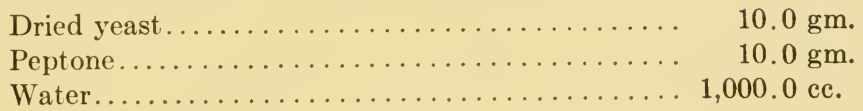

Medium 30

Ammonium Sulphate-glucose Solution

Ammonium sulphate $\left(\left(\mathrm{NH}_{4}\right)_{2} \mathrm{SO}_{4}\right) \ldots \ldots \ldots \ldots . \quad 5: 00 \mathrm{gm}$.

Dipotassium phosphate $\left(\mathrm{K}_{2} \mathrm{HPO}_{4}\right) \ldots \ldots \ldots \ldots .0 .75 \mathrm{gm}$.

Magnesium sulphate $\left(\mathrm{MgSO}_{4} \cdot 7 \mathrm{H}_{2} \mathrm{O}\right) \ldots \ldots \ldots \ldots .0 .10 \mathrm{gm}$.

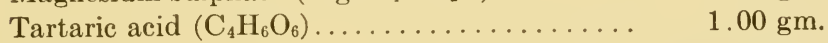

Glucose........................ $100.00 \mathrm{gm}$.

Distilled water................... 1,000.00 cc.

\section{Medium 31}

RaIsin Extract

Raisins......................... $375.0 \mathrm{gm}$.

Ammonium chloride $\left(\mathrm{NH}_{4} \mathrm{Cl}\right) \ldots \ldots \ldots \ldots \ldots .2 .0 \mathrm{gm}$.

Distilled water................... 1,000.0 ce.

Allow the raisins to stand in 1 liter of water at ice-box temperature for 1 to 2 days. Mash, add the ammonium chloride, cook in the steamer for 30 minutes, and filter. 


\section{Medium 32}

Synthetic Solution for Yeast ${ }^{1}$

Sucrose...................... $50.0 \mathrm{gm}$.

Ammonium sulphate $\left(\left(\mathrm{NH}_{4}\right)_{2} \mathrm{SO}_{4}\right) \ldots \ldots \ldots \ldots .6 .0 \mathrm{gm}$.

Mono-ammonium phosphate $\left(\mathrm{NH}_{4} \mathrm{H}_{2} \mathrm{PO}_{4}\right) \ldots . \quad 2.0 \mathrm{gm}$.

Potassium sulphate $\left(\mathrm{K}_{2} \mathrm{SO}_{4}\right) \ldots \ldots \ldots \ldots \ldots \ldots .4 .0 \mathrm{gm}$.

Magnesium sulphate $\left(\mathrm{MgSO}_{4} \cdot 7 \mathrm{H}_{2} \mathrm{O}\right) \ldots \ldots \ldots \ldots .2 .25 \mathrm{gm}$.

Calcium sulphate $\left(\mathrm{CaSO}_{4}\right) \ldots \ldots \ldots \ldots \ldots \ldots, 2.25 \mathrm{gm}$.

Tap water....................... $1,000.0$ ce.

${ }^{1}$ HAYdUCK, F., U. S. Patent, Reissue 15, 716.

\section{Medium 33}

Carrot Extract Agar for Spore Formation of Yeasts Carrots.......................... 1,000.0 gm.

Calcium sulphate $\left(\mathrm{CaSO}_{4} \cdot 2 \mathrm{H}_{2} \mathrm{O}\right) \ldots \ldots \ldots \ldots, 10.0 \mathrm{gm}$.

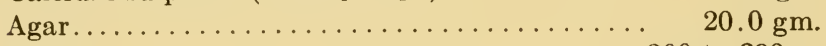

Water....................... 200 to 300 ce.

Wash and grind the carrots in a meat chopper. Add 200 to 300 cubic centimeters of tap water and boil for about 10 minutes. Filter through cheesecloth. Add the calcium sulphate and agar and heat in steamer for 30 minutes. Tube for slopes and sterilize at 15 pounds for 15 to 20 minutes.

\section{MEDIA FOR ACTINOMYCES ${ }^{2}$}

\section{Medium 34}

\section{Nitrate-SUCrose $\mathrm{AgAR}^{3}$}

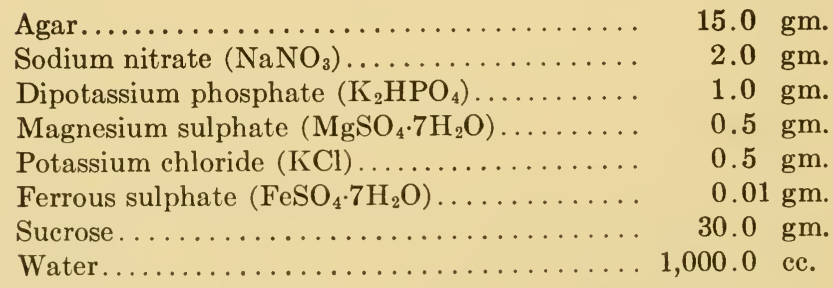

Reaction approximately $\mathrm{pH} 7.0$.

${ }^{2}$ For the cultivation of acid-resisting actinomyces, the reaction of these media as well as of medium 17 should be adjusted to $\mathrm{pH}$ 4.0. Jensen, H. L., Soil Sci. 25 : 225, 1928.

${ }^{3}$ Waksman, S. A., Soil Sci., 8: 71-215, 1919. 
Medium 35

Sodium Asparaginate-glycerol Agar ${ }^{1}$

Agar........................ $\quad 15.0$ gm.

Glycerol........................ 10.0 cc.

Dipotassium phosphate $\left(\mathrm{K}_{2} \mathrm{HPO}_{4}\right) \ldots \ldots \ldots \ldots . \quad 1.0 \mathrm{gm}$.

Sodium asparaginate............... $1.0 \mathrm{gm}$.

Water............................ 1,000.0 ce.

${ }^{1}$ Conn, H. J., N. Y. Agr. Expt. Sta., Tech. Bull. 60, 1917.

Reaction approximately $\mathrm{pH}$ 7.0.

\section{Medium 36}

Ammonium Sulphate-starch $\mathrm{AgaR}^{2}$

Agar.......................... $10.0 \mathrm{gm}$.

Starch (soluble)................ $10.0 \mathrm{gm}$.

Ammonium sulphate $\left(\left(\mathrm{NH}_{4}\right)_{2} \mathrm{SO}_{4}\right) \ldots \ldots \ldots \ldots .2 .0 \mathrm{gm}$.

Dipotassium phosphate $\left(\mathrm{K}_{2} \mathrm{HPO}_{4}\right) \ldots \ldots \ldots \ldots . \quad 1.0 \mathrm{gm}$.

Magnesium sulphate $\left(\mathrm{MgSO}_{4} \cdot 7 \mathrm{H}_{2} \mathrm{O}\right) \ldots \ldots \ldots \ldots . \quad 1.0 \mathrm{gm}$.

Sodium chloride................. $1.0 \mathrm{gm}$.

Calcium carbonate $\left(\mathrm{CaCO}_{3}\right) \ldots \ldots \ldots \ldots . .6 .0$.

Tap water.................... 1,000.0 cc.

${ }^{2}$ McBeth, I. G., and F. M. Scales, U. S. Dept. Agr., Bur. Pl. Ind. Bull. 266, 1913.

Mix the starch with a little cold water and stir well before adding the salts.

\section{MEDIA FOR PROTOZOA}

\section{Medium 37}

Nutrient or Beef Extract AgaR ${ }^{3}$

Agar . .

$15.0 \mathrm{gm}$.

Beef extract

$3.0 \mathrm{gm}$.

Peptone

$10.0 \mathrm{gm}$.

Sodium chloride $(\mathrm{NaCl})$

$5.0 \mathrm{gm}$.

Distilled water................... 1,000.0 cc.

${ }^{3}$ Sandon, H., and D. W. Cutler, J. Linn. Soc. Zool., $36: 1,1924$.

Adjust the reaction to $\mathrm{pH} 7.0$.

\section{Medium 38}

Hay Infusion

Meadow hay (finely chopped).......... $50.0 \mathrm{gm}$.

Tap water....................... 1,000.0 ce.

Boil for 2 hours and allow to stand over night. Filter. 


\section{Medium 39}

\section{Ammonium Lactate Solution}

Ammonium lactate....................

Ammonium chloride $\left(\mathrm{NH}_{4} \mathrm{Cl}\right) \ldots \ldots \ldots \ldots \ldots$

$0.1 \mathrm{gm}$.

Potassium chloride $(\mathrm{KCl}) \ldots \ldots \ldots \ldots \ldots$

$0.3 \mathrm{gm}$.

Magnesium sulphate $\left(\mathrm{MgSO}_{4} \cdot 7 \mathrm{H}_{2} \mathrm{O}\right) \ldots \ldots \ldots$

$0.3 \mathrm{gm}$.

Disodium phosphate $\left(\mathrm{Na}_{2} \mathrm{HPO}_{4}\right) \ldots \ldots \ldots$.

$0.001 \mathrm{gm}$.

Calcium chloride $\left(\mathrm{CaCl}_{2}\right) \ldots \ldots \ldots \ldots \ldots$.

$0.01 \mathrm{gm}$.

Glucose.........................

$0.2 \mathrm{gm}$.

Distilled water.

$0.4 \mathrm{gm}$

\section{Medium 40}

Mannitol Soll Extract

Soil extract (stock) ................. 100.0 cc.

Mannitol....................... $10.0 \mathrm{gm}$.

Dipotassium phosphate $\left(\mathrm{K}_{2} \mathrm{HPO}_{4}\right) \ldots \ldots \ldots \ldots, 0.5 \mathrm{gm}$.

Tap water..................... 900.0 ce.

\section{Medium 41}

\section{Mannitol-Phosphate Solution ${ }^{1}$}

Mannitol $\left(\mathrm{C}_{6} \mathrm{H}_{8}(\mathrm{OH})_{6}\right) \ldots \ldots \ldots \ldots \ldots \ldots$

$10.0 \mathrm{gm}$.

Magnesium sulphate $\left(\mathrm{MgSO}_{4} \cdot 7 \mathrm{H}_{2} \mathrm{O}\right) \ldots \ldots \ldots$

$0.2 \mathrm{gm}$.

Monopotassium phosphate $\left(\mathrm{KH}_{2} \mathrm{PO}_{4}\right) \ldots \ldots \ldots$.

$0.2 \mathrm{gm}$.

Sodium chloride $(\mathrm{NaCl}) \ldots \ldots \ldots \ldots \ldots \ldots$

$0.2 \mathrm{gm}$.

Calcium sulphate $\left(\mathrm{CaSO}_{4} \cdot 2 \mathrm{H}_{2} \mathrm{O}\right) \ldots \ldots \ldots \ldots$

$0.1 \mathrm{gm}$.

Calcium carbonate $\left(\mathrm{CaCO}_{3}\right) \ldots \ldots \ldots \ldots \ldots$

$5.0 \mathrm{gm}$.

Distilled water.................... 1,000.0 cc.

${ }^{1}$ Ashby, S. F., J. Agr. Sci., 2: 38, 1907.

Dissolve the phosphate separately in a little water and make the solution neutral to phenolphthalein with $N / 1 \mathrm{NaOH}$; then add to the other ingredients. For a solid medium add 15 grams of agar to each liter.

\section{MEDIA FOR ALGE}

\section{Medium 42}

\section{Calcium Nitrate Solution (Detmer's)}

Calcium nitrate $\left(\mathrm{Ca}\left(\mathrm{NO}_{3}\right)_{2}\right) \ldots \ldots \ldots \ldots \ldots .1 .0 \mathrm{gm}$.

Potassium chloride $(\mathrm{KCl}) \ldots \ldots \ldots \ldots \ldots \ldots . \quad 0.25 \mathrm{gm}$.

Magnesium sulphate $\left(\mathrm{MgSO}_{4} \cdot 7 \mathrm{H}_{2} \mathrm{O}\right) \ldots \ldots \ldots \ldots, 0.25 \mathrm{gm}$.

Monopotassium phosphate $\left(\mathrm{KH}_{2} \mathrm{PO}_{4}\right) \ldots \ldots \ldots \quad 0.25 \mathrm{gm}$.

Tap water...................... $1,000.0$ cc. 
Dilute 1 part of the above medium with 2 parts of tap water and add 0.01 per cent of ferric chloride $\left(\mathrm{FeCl}_{3} \cdot 6 \mathrm{H}_{2} \mathrm{O}\right)$.

\section{Medium 43}

\section{Sodium Nitrate Solution (Bristol's) ${ }^{1}$}

Monopotassium phosphate $\left(\mathrm{KH}_{2} \mathrm{PO}_{4}\right) \ldots \ldots$.

Sodium nitrate $\left(\mathrm{NaNO}_{3}\right) \ldots \ldots \ldots \ldots \ldots \ldots$

Magnesium sulphate $\left(\mathrm{MgSO}_{4} \cdot 7 \mathrm{H}_{2} \mathrm{O}\right) \ldots \ldots \ldots$

$0.5 \mathrm{gm}$.

$0.5 \mathrm{gm}$.

Calcium chloride $\left(\mathrm{CaCl}_{2}\right) \ldots \ldots \ldots \ldots \ldots \ldots$

$0.15 \mathrm{gm}$.

Sodium chloride $(\mathrm{NaCl}) \ldots \ldots \ldots \ldots \ldots \ldots$

$0.05 \mathrm{gm}$.

Ferric chloride $\left(\mathrm{FeCl}_{3} \cdot 6 \mathrm{H}_{2} \mathrm{O}\right) \ldots \ldots \ldots \ldots \ldots, 0.01 \mathrm{gm}$.

Water........................ 1,000.0 c.

${ }^{1}$ Bristol, B. M., Ann. Bot., 34: 35-79, 1920.

Because of the special sensitiveness of the algæ to copper, it is well to avoid distilled water unless from glass.

\section{MEDIA FOR UREA BACTERIA}

\section{Medium 44}

\section{Urea Citrate Solution 2}

Urea $\left(\mathrm{CO}\left(\mathrm{NH}_{2}\right)_{2}\right) \ldots \ldots \ldots \ldots \ldots \ldots \ldots \ldots . \quad 30.0 \mathrm{gm}$.

Dipotassium phosphate $\left(\mathrm{K}_{2} \mathrm{HPO}_{4}\right) \ldots \ldots \ldots \ldots . \quad 0.5 \mathrm{gm}$.

Calcium citrate $\left(\mathrm{Ca}_{3}\left(\mathrm{C}_{6} \mathrm{H}_{5} \mathrm{O}_{7}\right)_{2} \cdot 4 \mathrm{H}_{2} \mathrm{O}\right) \ldots \ldots \ldots \ldots \quad 10.0 \mathrm{gm}$.

Tap water.......................

${ }^{2}$ Söhngen, N. G., Centr. Bakt. II Abt., 23: 91-98, 1909.

Reaction about pH 7.2.

\section{Medium 45}

\section{Urea Solution ${ }^{3}$}

Urea......................... $20.0 \mathrm{gm}$.

Dipotassium phosphate $\left(\mathrm{K}_{2} \mathrm{HPO}_{4}\right) \ldots \ldots \ldots \ldots . \quad 1.0 \mathrm{gm}$.

Calcium chloride $\left(\mathrm{CaCl}_{2}\right) \ldots \ldots \ldots \ldots \ldots \ldots .0 .1 \mathrm{gm}$.

Magnesium sulphate $\left(\mathrm{MgSO}_{4} \cdot 7 \mathrm{H}_{2} \mathrm{O}\right) \ldots \ldots \ldots .0 .3 \mathrm{gm}$.

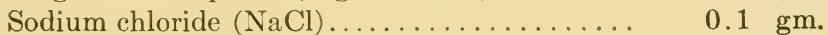

Ferric chloride $\left(\mathrm{FeCl}_{3} \cdot 6 \mathrm{H}_{2} \mathrm{O}\right) \ldots \ldots \ldots \ldots \ldots \ldots .0 .01 \mathrm{gm}$.

Beef extract.................... $5.0 \mathrm{gm}$.

Tap water.................... 1,000.0 cc.

${ }^{3}$ Vienoever, A., Centr. Bakt., II Abt., 39 : 209-359, 1913. 


\section{Medium 46}

Urea Soll Extract ${ }^{1}$

Urea $\left(\mathrm{CO}\left(\mathrm{NH}_{2}\right)_{2}\right)$. . . $50.0 \mathrm{gm}$.

Dipotassium phosphate $\left(\mathrm{K}_{2} \mathrm{HPO}_{4}\right) \ldots \ldots \ldots \ldots, 0.5 \mathrm{gm}$. Soil extract (stock) ................. 100.0 cc.

Tap water..................... 900.0 cc.

${ }^{1}$ Löhnis, F. Centr. Bakt., II Abt., 14: 714-723, 1905.

\section{Medium 47}

Urea Boulllon Gelatin or Agar

Urea $\left(\mathrm{CO}\left(\mathrm{NH}_{2}\right)_{2}\right) \ldots \ldots \ldots \ldots \ldots \ldots \ldots . . .6 \mathrm{gm}$.

Gelatin.................... 120 to $150.0 \mathrm{gm}$. or

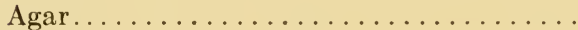

$15.0 \mathrm{gm}$.

Bouillon. $1,000.0 \mathrm{cc}$.

Reaction about $\mathrm{pH} 7.5$.

\section{MEDIA FOR NITRIFYING BACTERIA}

\section{Medium 48}

\section{Ammonium Sulphate Solution 2}

Ammonium sulphate $\left(\left(\mathrm{NH}_{4}\right)_{2} \mathrm{SO}_{4}\right)$... $1.0 \mathrm{gm}$.

Dipotassium phosphate $\left(\mathrm{K}_{2} \mathrm{HPO}_{4}\right) \ldots \ldots \ldots \ldots$. $1.0 \mathrm{gm}$.

Sodium chloride $(\mathrm{NaCl}) \ldots \ldots \ldots \ldots \ldots \ldots$ $2.0 \mathrm{gm}$.

Magnesium sulphate $\left(\mathrm{MgSO}_{4} \cdot 7 \mathrm{H}_{2} \mathrm{O}\right) \ldots \ldots \ldots \ldots$

Ferrous sulphate $\left(\mathrm{FeSO}_{4} \cdot 7 \mathrm{H}_{2} \mathrm{O}\right) \ldots \ldots \ldots \ldots$

Magnesium carbonate $\left(\mathrm{MgCO}_{3}\right) \ldots \ldots \ldots \ldots$ excess

Distilled water................... 1,000.0 cc.

2 Winogradksy, S. Lafar's "Handb. techn. mykol.," 3: 132-181, 1904.

In order to prevent any loss of ammonia, it is desirable to sterilize the magnesium carbonate separately. When cool add an excess of the magnesium carbonate to each flask.

\section{Medium 49}

\section{Magnesium Ammonium Phosphate Solution}

Magnesium ammonium phosphate $\left(\mathrm{MgNH}_{4} \mathrm{PO}_{4}\right.$-$\left.6 \mathrm{H}_{2} \mathrm{O}\right) \ldots \ldots \ldots \ldots \ldots \ldots \ldots \ldots \ldots \ldots \ldots \ldots \ldots \ldots \ldots$

Dipotassium phosphate $\left(\mathrm{K}_{2} \mathrm{HPO}_{4}\right) \ldots \ldots \ldots \ldots$

Sodium chloride $(\mathrm{NaCl}) \ldots \ldots \ldots \ldots \ldots \ldots$

Magnesium sulphate $\left(\mathrm{MgSO}_{4} \cdot 7 \mathrm{H}_{2} \mathrm{O}\right) \ldots \ldots \ldots$

Ferrous sulphate $\left(\mathrm{FeSO}_{4} \cdot 7 \mathrm{H}_{2} \mathrm{O}\right)$ $2.0 \mathrm{gm}$. $1.0 \mathrm{gm}$. $2.0 \mathrm{gm}$. $0.5 \mathrm{gm}$.

Magnesium carbonate $\left(\mathrm{MgCO}_{3}\right) \ldots \ldots \ldots \ldots \ldots . \quad 5.0 \mathrm{gm}$. Tap water...................... 1,000.0 cc. 


\section{Medium 50}

\section{Sodium Ammonium Phosphate Solution}

Sodium ammonium phosphate $\left(\mathrm{Na}\left(\mathrm{NH}_{4}\right) \mathrm{HPO}_{4} \cdot-\right.$

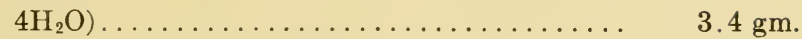

Potassium chloride $(\mathrm{KCl}) \ldots \ldots \ldots \ldots \ldots \ldots .2 .0 \mathrm{gm}$.

Magnesium sulphate $\left(\mathrm{MgSO}_{4} \cdot 7 \mathrm{H}_{2} \mathrm{O}\right) \ldots \ldots \ldots \ldots \quad 0.5 \mathrm{gm}$.

Ferrous sulphate $\left(\mathrm{FeSO}_{4} \cdot 7 \mathrm{H}_{2} \mathrm{O}\right) \ldots \ldots \ldots \ldots$ trace

Magnesium carbonate $\left(\mathrm{MgCO}_{3}\right) \ldots \ldots \ldots \ldots$ excess

Distilled water..................... 1,000.0 cc.

To prevent a loss of ammonia do not add the $\mathrm{MgCO}_{3}$ until after sterilization

\section{Medium 51}

\section{Sodium Nitrite Solution ${ }^{1}$}

Sodium nitrite $\left(\mathrm{NaNO}_{2}\right) \ldots \ldots \ldots \ldots \ldots \ldots \ldots . \quad 1.0 \mathrm{gm}$.

Sodium carbonate $\left(\mathrm{Na}_{2} \mathrm{CO}_{3}\right) \ldots \ldots \ldots \ldots \ldots \ldots . \quad 1.0 \mathrm{gm}$.

Dipotassium phosphate $\left(\mathrm{K}_{2} \mathrm{HPO}_{4}\right) \ldots \ldots \ldots \ldots .0 .5 \mathrm{gm}$.

Sodium chloride $(\mathrm{NaCl}) \ldots \ldots \ldots \ldots \ldots \ldots \ldots . \quad 0.5 \mathrm{gm}$.

Magnesium sulphate $\left(\mathrm{MgSO}_{4} \cdot 7 \mathrm{H}_{2} \mathrm{O}\right) \ldots \ldots \ldots \ldots \quad 0.3 \mathrm{gm}$.

Ferrous sulphate $\left(\mathrm{FeSO}_{4} \cdot 7 \mathrm{H}_{2} \mathrm{O}\right) \ldots \ldots \ldots \ldots$ trace

Distilled water................... 1,000.0 cc.

${ }^{1}$ Fred, E. B., and A. Davenport, Soil Sci., 11: 389-404, 1921.

\section{Medium 52}

Medium for Oxidation of Ammonia and Nitrite to Nitrate
Ammonium sulphate $\left(\left(\mathrm{NH}_{4}\right)_{2} \mathrm{SO}_{4}\right) \ldots \ldots \ldots \ldots$.
$2.0 \mathrm{gm}$.
Dipotassium phosphate $\left(\mathrm{K}_{2} \mathrm{HPO}_{4}\right) \ldots \ldots \ldots \ldots$.
$1.0 \mathrm{gm}$.
Magnesium sulphate $\left(\mathrm{MgSO}_{4} \cdot 7 \mathrm{H}_{2} \mathrm{O}\right) \ldots \ldots \ldots$.
$0.5 \mathrm{gm}$.
Sodium chloride $(\mathrm{NaCl})$
$2.0 \mathrm{gm}$.
Ferrous sulphate $\left(\mathrm{FeSO}_{4} \cdot 7 \mathrm{H}_{2} \mathrm{O}\right) \ldots \ldots \ldots \ldots$ trace
Calcium carbonate................. $5.0 \mathrm{gm}$.
Tap water....................... 1,000.0 cc.

Add the calcium carbonate after sterilization.

\section{Medium 53}

\section{Washed Agar for Nitrifying Bacteria}

Agar (washed) ${ }^{2} \ldots \ldots \ldots \ldots \ldots \ldots \ldots \ldots \ldots .25 .0 \mathrm{gm}$.

Water........................... 1,000.0 ce.

${ }^{2}$ Allow the agar to wash in running water for 5 to 7 days, and dry at $60^{\circ} \mathrm{C}$. 
Tube the agar in 10-cubic centimeter portions and sterilize. To this melted agar, at $45^{\circ} \mathrm{C}$. in tubes or Petri dishes, add 1cubic centimeter portion of the following salts.

1. Dipotassium phosphate $\left(\mathrm{K}_{2} \mathrm{HPO}_{4}\right) \ldots \ldots \ldots \ldots, 1.5 \mathrm{gm}$. Water........................ 100.0 ce.

2. Ammonium sulphate $\left(\left(\mathrm{NH}_{4}\right)_{2} \mathrm{SO}_{4}\right) \ldots \ldots \ldots \ldots \quad 1.5 \mathrm{gm}$. Magnesium sulphate $\left(\mathrm{MgSO}_{4} \cdot 7 \mathrm{H}_{2} \mathrm{O}\right) \ldots \ldots \ldots, 0.75 \mathrm{gm}$. Ferric sulphate $\left(\mathrm{Fe}_{2}\left(\mathrm{SO}_{4}\right)_{3} \cdot 9 \mathrm{H}_{2} \mathrm{O}\right) \ldots \ldots \ldots \ldots, 0.02 \mathrm{gm}$. Water........................ 100.0 cc.

3. Sodium chloride $(\mathrm{NaCl}) \ldots \ldots \ldots \ldots \ldots \ldots \ldots .3 .0 \mathrm{gm}$.

Sodium carbonate $\left(\mathrm{Na}_{2} \mathrm{CO}_{3}\right) \ldots \ldots \ldots \ldots \ldots, 1.5 \mathrm{gm}$.

Tap water................... 100.0 cc.

4. Sodium nitrite $\left(\mathrm{NaNO}_{2}\right) \ldots \ldots \ldots \ldots \ldots \ldots \ldots .1 .5 \mathrm{gm}$.

Sodium carbonate $\left(\mathrm{Na}_{2} \mathrm{CO}_{3}\right) \ldots \ldots \ldots \ldots \ldots, 1.5 \mathrm{gm}$.

Water......................... 100.0 ce.

5. Magnesium sulphate $\left(\mathrm{MgSO}_{4} \cdot 7 \mathrm{H}_{2} \mathrm{O}\right) \ldots \ldots \ldots \mid 0.45 \mathrm{gm}$.

Sodium chlorid $(\mathrm{NaCl}) \ldots \ldots \ldots \ldots \ldots \ldots, 0.75 \mathrm{gm}$.

Ferric sulphate $\left(\mathrm{Fe}_{2}\left(\mathrm{SO}_{4}\right)_{3} \cdot 9 \mathrm{H}_{2} \mathrm{O}\right) \ldots \ldots \ldots \ldots, 0.02 \mathrm{gm}$.

Water....................... 100.0 cc.

For ammonia oxidation add 1 cubic centimeter of the stock solutions numbers 1,2 , and 3 , to 10 cubic centimeters of the melted agar.

For the nitrite oxidation, add 1 cubic centimeter of stock solutions numbers 1,4 , and 5 .

Agar media prepared in this way should remain clear.

\section{Medium 54}

Silicio Acid Gel for Nitrite-forming Bacteria

Prepare a series of silica-gel plates, according to the method outlined on p. 6 . To each plate add 2.5 cubic centimeters of the medium (a), 1 cubic centimeter of medium (b), 1 drop of $(c)$ and a few drops of $(d)$ to give a milky appearance. Mix the solutions and place the open plates in incubator, at $60^{\circ} \mathrm{C}$., to evaporate excess of surface liquid.

(a) Ammonium sulphate $\left(\left(\mathrm{NH}_{4}\right)_{2} \mathrm{SO}_{4}\right)$

$1.5 \mathrm{gm}$.

Dipotassium phosphate $\left(\mathrm{K}_{2} \mathrm{HPO}_{4}\right) \ldots \ldots \ldots$.

$0.5 \mathrm{gm}$.

Magnesium sulphate $\left(\mathrm{MgSO}_{4} \cdot 7 \mathrm{H}_{2} \mathrm{O}\right) \ldots \ldots$.

$0.25 \mathrm{gm}$.

Distilled water................. 100.0 cc.

(b) Ferrous sulphate $\left(\mathrm{FeSO}_{4} \cdot 7 \mathrm{H}_{2} \mathrm{O}\right) \ldots \ldots \ldots \ldots, 1.0 \mathrm{gm}$.

Distilled water................... 100.0 cc.

(c) Saturated sodium chloride solution.

(d) A suspension of powdered $\mathrm{MgCO}_{3}$ in distilled water. 


\section{MEDIA FOR NITRATE-REDUCING AND DENITRIFYING BACTERIA}

\section{Medium 55}

Asparagin Nitrate-citrate (Giltay's) Solution

(a) Potassium nitrate $\left(\mathrm{KNO}_{3}\right) \ldots \ldots \ldots \ldots \ldots \ldots, 1.0 \mathrm{gm}$.

Asparagin $\left(\mathrm{C}_{4} \mathrm{H}_{8} \mathrm{~N}_{2} \mathrm{O}_{3} \cdot \mathrm{H}_{2} \mathrm{O}\right) \ldots \ldots \ldots \ldots \ldots, 1.0 \mathrm{gm}$.

Distilled water................. 250.0 cc.

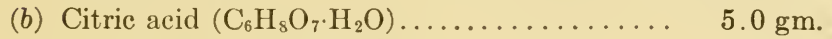

or neutral sodium citrate........... $8.5 \mathrm{gm} . \checkmark$

Monopotassium phosphate $\left(\mathrm{KH}_{2} \mathrm{PO}_{4}\right) \ldots \ldots$. $1.0 \mathrm{gm}$.-

Magnesium sulphate $\left(\mathrm{MgSO}_{4} \cdot 7 \mathrm{H}_{2} \mathrm{O}\right) \ldots \ldots \ldots, 1.0 \mathrm{gm}$.

Calcium chloride $\left(\mathrm{CaCl}_{2} \cdot 6 \mathrm{H}_{2} \mathrm{O}\right) \ldots \ldots \ldots \ldots, 0.2 \mathrm{gm}$.

Ferric chloride $\left(\mathrm{FeCl}_{3} \cdot 6 \mathrm{H}_{2} \mathrm{O}\right) \ldots \ldots \ldots \ldots \ldots$ trace -

Distilled water.................. 250.0 cc.

Neutralize the citric acid solution with a 10 per cent solution of sodium or potassium hydroxide, using phenolphthalein as an indicator. Mix the two solutions and add sufficient water to make 1000.0 cubic centimeters. If the asparagin and potassium nitrate are dissolved along with the other salts, a decomposition may occur. This is marked by a browning of the liquid due to the presence of nitrous acid.

For a solid medium add 15 grams of agar to 1 liter.

\section{Medium 56}

\section{Potassium Nitrate-glucose Solution}

\begin{tabular}{|c|c|}
\hline $\left.\mathrm{O}_{3}\right)$ & 1.0 \\
\hline$V$ & \\
\hline 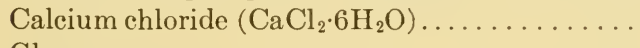 & \\
\hline & \\
\hline & \\
\hline
\end{tabular}

\section{Medium 57}

Potassium Nitrate-ethyl alcohol Solution ${ }^{1}$
Dipotassium phosphate $\left(\mathrm{K}_{2} \mathrm{HPO}_{4}\right) \ldots \ldots \ldots \ldots .0 .5 \mathrm{gm}$.
Potassium nitrate $\left(\mathrm{KNO}_{3}\right) \ldots \ldots \ldots \ldots \ldots \ldots, 10.0 \mathrm{gm}$.
Ethyl alcohol $\left(\mathrm{C}_{2} \mathrm{H}_{5} \mathrm{OH}\right) \ldots \ldots \ldots \ldots \ldots \ldots \ldots .6 .0$ ec.
Tap water.................... 1,000.0 ec.

${ }^{1}$ Beijerinck, M. W., Centr. Bakt., II Abt., 25: 35, 1910. 
Medium 58

Potassium Nitrate-filter Paper ${ }^{1}$

Dipotassium phosphate $\left(\mathrm{K}_{2} \mathrm{HPO}_{4}\right) \ldots \ldots \ldots \ldots .0 .5 \mathrm{gm}$.

Potassium nitrate $\left(\mathrm{KNO}_{3}\right) \ldots \ldots \ldots \ldots \ldots .2 .5 \mathrm{gm}$.

Filter paper in strips............. $20.0 \mathrm{gm}$.

Tap water........................ 1,000.0 cc.

${ }^{1}$ Van Iterson, Centr. Bakt., II Abt., 11:689, 1904.

\section{Medium 59}

Potassium Nitrate-thiosulphate Solution ${ }^{2}$

Sodium thiosulphate $\left(\mathrm{Na}_{2} \mathrm{~S}_{2} \mathrm{O}_{3} \cdot 5 \mathrm{H}_{2} \mathrm{O}\right) \ldots \ldots \ldots . \quad 5.0 \mathrm{gm}$.

Potassium nitrate $\left(\mathrm{KNO}_{3}\right) \ldots \ldots \ldots \ldots \ldots \ldots \ldots . \quad 5.0 \mathrm{gm}$.

Sodium bicarbonate $\left(\mathrm{NaHCO}_{3}\right) \ldots \ldots \ldots \ldots \ldots . \quad 1.0 \mathrm{gm}$.

Dipotassium phosphate $\left(\mathrm{K}_{2} \mathrm{HPO}_{4}\right) \ldots \ldots \ldots \ldots .0 .2 \mathrm{gm}$.

Magnesium chloride $\left(\mathrm{MgCl}_{2} \cdot 6 \mathrm{H}_{2} \mathrm{O}\right) \ldots \ldots \ldots \ldots \ldots .0 .1 \mathrm{gm}$.

Calcium chloride $\left(\mathrm{CaCl}_{2} \cdot 6 \mathrm{H}_{2} \mathrm{O}\right) \ldots \ldots \ldots \ldots \ldots$ trace

Ferric chloride $\left(\mathrm{FeCl}_{3} \cdot 6 \mathrm{H}_{2} \mathrm{O}\right) \ldots \ldots \ldots \ldots \ldots$ trace

Distilled water................... $1,000.0$ cc.

${ }^{2}$ Lieske, R., Ber. d. Deutsch. Bot. Gessell., 30: 12-22, 1912.

\section{MEDIA FOR THE REDUCTION OF SULPHATES AND OTHER} SULPHUR COMPOUNDS

\section{Medium 60}

\section{Asparagin-sodium Lactate Solution ${ }^{3}$}

Asparagin $\left(\mathrm{C}_{4} \mathrm{H}_{8} \mathrm{~N}_{2} \mathrm{O}_{3} \cdot \mathrm{H}_{2} \mathrm{O}\right) \ldots \ldots \ldots \ldots \ldots$.

Sodium lactate $\left(\mathrm{NaC}_{3} \mathrm{H}_{5} \mathrm{O}_{3}\right) \ldots \ldots \ldots \ldots \ldots \ldots$

Dipotassium phosphate $\left(\mathrm{K}_{2} \mathrm{HPO}_{4}\right) \ldots \ldots \ldots \ldots$

Magnesium sulphate $\left(\mathrm{MgSO}_{4} \cdot 7 \mathrm{H}_{2} \mathrm{O}\right) \ldots \ldots \ldots$

Ferrous sulphate $\left(\mathrm{FeSO}_{4} \cdot 7 \mathrm{H}_{2} \mathrm{O}\right) \ldots \ldots \ldots \ldots$ trace

Tap water................... 1,000.0 ec.

${ }^{3}$ Van Delden, A., Centr. Bakt., II Abt., 11: 83, 1904.

\section{Medium 61}

Sodium Lactate-ammonium Sulphate Solution

Ammonium sulphate $\left(\left(\mathrm{NH}_{4}\right)_{2} \mathrm{SO}_{4}\right) \ldots \ldots \ldots \ldots$

$2.0 \mathrm{gm}$.

Dipotassium phosphate $\left(\mathrm{K}_{2} \mathrm{HPO}_{4}\right) \ldots \ldots \ldots \ldots$.

$0.5 \mathrm{gm}$.

Sodium lactate $\left(\mathrm{NaC}_{3} \mathrm{H}_{5} \mathrm{O}_{3}\right) \ldots \ldots \ldots \ldots \ldots \ldots$

$5.0 \mathrm{gm}$.

Ferrous sulphate $\left(\mathrm{FeSO}_{4} \cdot 7 \mathrm{H}_{2} \mathrm{O}\right) \ldots \ldots \ldots \ldots$ trace

Tap water...................... 1,000.0 ec.

To prepare a solid medium add the above ingredients to 15 per cent gelatin. Heat the medium in a steamer until the 
precipitate has settled, and filter. Sterilize at a low temperature, about 10 pounds' pressurè for 15 minutes, or in the steamer for 20 minutes for 3 consecutive days.

\section{Medium 62}

\section{Yeast-water Sodium Sulphite Agar}

\begin{tabular}{|c|c|}
\hline & \\
\hline & \\
\hline phite $\left(\mathrm{Na}_{2} \mathrm{SO}_{3}\right)$ & \\
\hline action $\mathrm{pH}$ & 1,000 \\
\hline
\end{tabular}

For the culture of certain microorganisms it is desirable to add 3 per cent of sucrose.

\section{Medium 63}

\section{Asparagin-sodium Lactate Gelatin}

Asparagin $\left(\mathrm{C}_{4} \mathrm{H}_{8} \mathrm{~N}_{2} \mathrm{O}_{3} \cdot \mathrm{H}_{2} \mathrm{O}\right) \ldots \ldots \ldots$.

Sodium lactate $\left(\mathrm{NaC}_{3} \mathrm{H}_{5} \mathrm{O}_{3}\right) \ldots \ldots \ldots \ldots$

$1.0 \mathrm{gm}$.

Dipotassium phosphate $\left(\mathrm{K}_{2} \mathrm{HPO}_{4}\right) \ldots$.

$5.0 \mathrm{gm}$.

Magnesium sulphate $\left(\mathrm{MgSO}_{4} \cdot 7 \mathrm{H}_{2} \mathrm{O}\right) \ldots$.

Iron-ammonium sulphate $\left(\mathrm{FeSO}_{4} \cdot\left(\mathrm{NH}_{4}\right)_{2}\right.$

$\left.\left(\mathrm{SO}_{4}\right) \cdot 6 \mathrm{H}_{2} \mathrm{O}\right) \ldots \ldots \ldots \ldots \ldots \ldots \ldots$

Gelatin.................... 120.0 to $150.0 \mathrm{gm}$.

Distilled water............... 1,000.0 cc.

Sterilize in the autoclave at 10 pounds' pressure for 15 minutes. Cool in ice water.

\section{Medium 64}

Beef Extract-sodium Sulphite Agar ${ }^{1}$

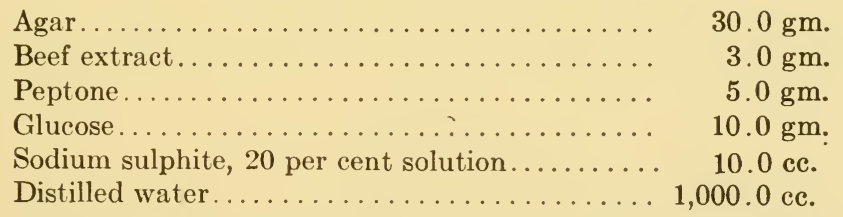

${ }^{1}$ Wilson, W. J., and E. Maud McV. Blair, J. Hyg., 24 : 111-119, 1925.

Adjust the reaction to $\mathrm{pH} 6.6$ to 7.0 .

Add the glucose just before sterilization and fill in small flasks of 100 cubic centimeters each. To 100 cubic centimeters of this agar while melted add 1 cubic centimeter of sterile 8 per cent ferric chloride $\left(\mathrm{FeCl}_{3} \cdot 6 \mathrm{H}_{2} \mathrm{O}\right)$ solution, 0.6 cubic centimeter of a 
10 per cent sodium hydroxide $(\mathrm{NaOH})$ solution and 10.0 cubic centimeters of a 20 per cent sodium sulphite $\left(\mathrm{Na}_{2} \mathrm{SO}_{3}\right)$ solution. Now dilute this agar medium with an equal amount of a water suspension of the bacteria. Pour deep plates.

\section{MEDIA FOR SULPHUR-OXIDIZING BACTERIA}

\section{Medium 65}

\section{Thiosulphate Solution ${ }^{1}$}

Sodium thiosulphate $\left(\mathrm{Na}_{2} \mathrm{~S}_{2} \mathrm{O}_{3} \cdot 5 \mathrm{H}_{2} \mathrm{O}\right) \ldots \ldots \ldots$

$5.0 \mathrm{gm}$.

Ammonium chloride $\left(\mathrm{NH}_{4} \mathrm{Cl}\right) \ldots \ldots \ldots \ldots \ldots$

$0.1 \mathrm{gm}$.

Sodium bicarbonate $\left(\mathrm{NaHCO}_{3}\right) \ldots \ldots \ldots \ldots$.

$1.0 \mathrm{gm}$.

Disodium phosphate $\left(\mathrm{Na}_{2} \mathrm{HPO}_{4} \cdot 2 \mathrm{H}_{2} \mathrm{O}\right) \ldots \ldots \ldots$.

$0.2 \mathrm{gm}$.

Magnesium chloride $\left(\mathrm{MgCl}_{2} \cdot 6 \mathrm{H}_{2} \mathrm{O}\right) \ldots \ldots \ldots \ldots, 0.1 \mathrm{gm}$.

Tap water..................... 1,000.0 cc.

${ }^{1}$ Beijerinck, M. W., Centr. Bakt., II Abt., 11: 593-599, 1904.

Sterilize the thiosulphate and acid carbonate separately in a small amount of water and when cool add to the solution of the other salts. A trace of ferrous sulphate (sterile solution) should also be added after sterilization.

\section{Medium 66}

\section{Thiosulphate-Nitrate Solution ${ }^{2}$}

Sodium thiosulphate $\left(\mathrm{Na}_{2} \mathrm{~S}_{2} \mathrm{O}_{3} \cdot 5 \mathrm{H}_{2} \mathrm{O}\right) \ldots \ldots \ldots . \quad 2.0 \mathrm{gm}$.

Potassium nitrate $\left(\mathrm{KNO}_{3}\right) \ldots \ldots \ldots \ldots \ldots \ldots .1 .0 \mathrm{gm}$.

Ammonium chloride $\left(\mathrm{NH}_{4} \mathrm{Cl}\right) \ldots \ldots \ldots \ldots \ldots .0 .1 \mathrm{gm}$.

Sodium bicarbonate $\left(\mathrm{NaHCO}_{3}\right) \ldots \ldots \ldots \ldots \ldots . \quad 1.0 \mathrm{gm}$.

Magnesium chloride $\left(\mathrm{MgCl}_{2} \cdot 6 \mathrm{H}_{2} \mathrm{O}\right) \ldots \ldots \ldots \ldots .0 .1 \mathrm{gm}$.

Disodium phosphate $\left(\mathrm{Na}_{2} \mathrm{HPO}_{4} \cdot 2 \mathrm{H}_{2} \mathrm{O}\right) \ldots \ldots \ldots, 0.2 \mathrm{gm}$.

Distilled water.................... 1,000.0 cc.

${ }^{2}$ Trautwein, K., Centr. Bakt. II Abt., 53: 513-548, 1921.

\section{Medium 67}

\section{Thiosulphate-AGAR ${ }^{3}$}

Sodium thiosulphate $\left(\mathrm{Na}_{2} \mathrm{~S}_{2} \mathrm{O}_{3} \cdot 5 \mathrm{H}_{2} \mathrm{O}\right) \ldots \ldots \ldots . \quad 5.0 \mathrm{gm}$.

Dipotassium phosphate $\left(\mathrm{K}_{2} \mathrm{HPO}_{4}\right) \ldots \ldots \ldots \ldots \ldots .0 .1 \mathrm{gm}$.

Sodium bicarbonate $\left(\mathrm{NaHCO}_{3}\right) \ldots \ldots \ldots \ldots \ldots .0 .2 \mathrm{gm}$.

Ammonium chloride $\left(\mathrm{NH}_{4} \mathrm{Cl}\right) \ldots \ldots \ldots \ldots \ldots . . .6 .1 \mathrm{gm}$.

Agar........................... $20.0 \mathrm{gm}$.

Tap water...................... 1,000.0 cc.

${ }^{3}$ Beijerinck, M. W., Centr. Bakt., II Abt., 11: 593-599, 1904. 
For certain organisms it is advisable to add an excess of $\mathrm{CaCO}_{3}$.

\section{Medium 68}

\section{Sulphur-Phosphate Medium $^{1}$}

Ammonium sulphate $\left(\left(\mathrm{NH}_{4}\right)_{2} \mathrm{SO}_{4}\right) \ldots \ldots \ldots$.

Monopotassium phosphate $\left(\mathrm{KH}_{2} \mathrm{PO}_{4}\right) \ldots \ldots \ldots$.

$0.2 \mathrm{gm}$.

Magnesium sulphate $\left(\mathrm{MgSO}_{4} \cdot 7 \mathrm{H}_{2} \mathrm{O}\right) \ldots \ldots \ldots$

$3.0 \mathrm{gm}$.

Calcium chloride $\left(\mathrm{CaCl}_{2} \cdot 6 \mathrm{H}_{2} \mathrm{O}\right) \ldots \ldots \ldots \ldots$.

$0.5 \mathrm{gm}$.

$0.25 \mathrm{gm}$.

Ferrous sulphate $\left(\mathrm{FeSO}_{4} \cdot 7 \mathrm{H}_{2} \mathrm{O}\right) \ldots \ldots \ldots \ldots$.

trace

Sulphur, powdered................ $10.0 \mathrm{gm}$.

Distilled water.................. 1,000.0 ce.

1 Waksman, S. A., Soil Sci., $13: 329,1922$.

The sulphur is weighed out into the individual containers, usually 1-gram portions into 250-cubic centimeter Erlenmeyer flasks, and 100-cubic centimeter portions of the liquid medium added. The reaction of the medium is about $\mathrm{pH}$ 4.0. The flasks are sterilized in flowing steam on 3 consecutive days.

\section{Medium 69}

\section{Sodidm-thiosulphate AgaR ${ }^{2}$}

Agar........................ $20.0 \mathrm{gm}$.

Sodium thiosulphate $\left(\mathrm{Na}_{2} \mathrm{~S}_{3} \mathrm{O}_{3} \cdot 5 \mathrm{H}_{2} \mathrm{O}\right) \ldots \ldots . \quad 5.0 \mathrm{gm}$.

Ammonium chloride $\left(\mathrm{NH}_{4} \mathrm{Cl}\right) \ldots \ldots \ldots \ldots \ldots .0 .1 \mathrm{gm}$.

Calcium chloride $\left(\mathrm{CaCl}_{2} \cdot 6 \mathrm{H}_{2} \mathrm{O}\right) \ldots \ldots \ldots \ldots \ldots, 0.25 \mathrm{gm}$.

Magnesium chloride $\left(\mathrm{MgCl}_{2} \cdot 6 \mathrm{H}_{2} \mathrm{O}\right) \ldots \ldots \ldots \ldots . .60 .1 \mathrm{gm}$.

Monopotassium phosphate $\left(\mathrm{KH}_{2} \mathrm{PO}_{4}\right) \ldots \ldots . \quad 3.0 \mathrm{gm}$.

Distilled water................... 1,000.0 cc.

2 Waksman, S. A., J. Bact., $7:$ 605, 1922.

The medium is prepared as usual and sterilized at 15 pounds' pressure for 15 minutes.

\section{Medium 70}

Solution for the Reduction of Hydrogen Sulphide

Ammonium sulphate $\left(\left(\mathrm{NH}_{4}\right)_{2} \mathrm{SO}_{4}\right) \ldots \ldots \ldots \ldots \ldots, 1.5 \mathrm{gm}$.

Potassium chloride $(\mathrm{KCl}) \ldots \ldots \ldots \ldots \ldots \ldots .0 .05 \mathrm{gm}$.

Magnesium sulphate $\left(\mathrm{MgSO}_{4} \cdot 7 \mathrm{H}_{2} \mathrm{O}\right) \ldots \ldots \ldots \ldots, 0.05 \mathrm{gm}$.

Dipotassium phosphate $\left(\mathrm{K}_{2} \mathrm{HPO}_{4}\right) \ldots \ldots \ldots \ldots \ldots, 0.05 \mathrm{gm}$.

Calcium nitrate $\left(\mathrm{Ca}\left(\mathrm{NO}_{3}\right)_{2}\right) \ldots \ldots \ldots \ldots \ldots \ldots, 0.01 \mathrm{gm}$.

Calcium carbonate $\left(\mathrm{CaCO}_{3}\right) \ldots \ldots \ldots \ldots \ldots . \ldots . \ldots .$. 
Sterilize in small flasks or tubes. After inoculation incubate under an atmosphere of hydrogen sulphide as shown below. ${ }^{1}$ To obtain a solid medium, the amount of $\mathrm{CaCO}_{3}$ in the above solution is increased to $50 \mathrm{gm}$. per liter and 0.5 per cent agar is added.

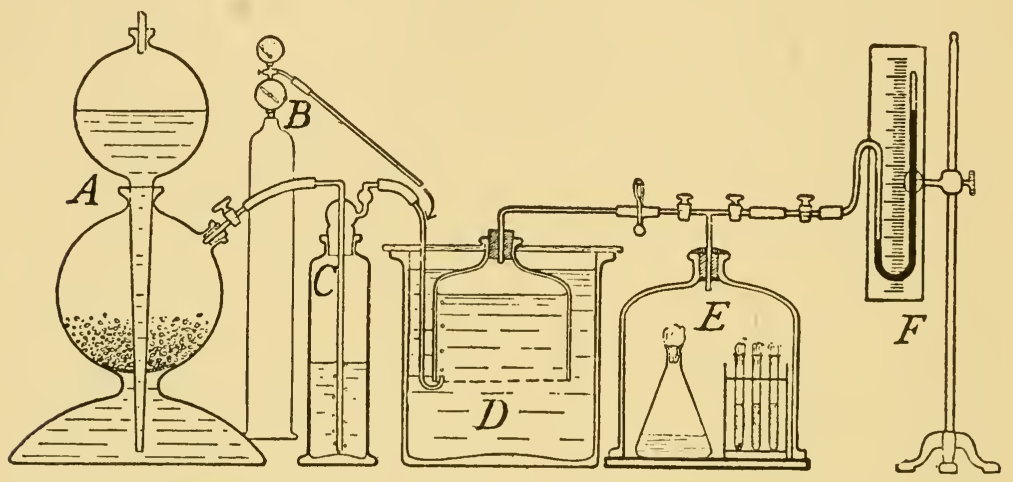

FIG. 1.-Apparatus for the cultivation of pure cultures of sulfur bacteria using $\mathrm{H}_{2} \mathrm{~S}$ as a source of energy. $A$, apparatus for generation of $\mathrm{H}_{2} \mathrm{~S} ; B$, hydrogen tank; $C$, wash flask; $D$, gasometer; $E$, culture jar; $F$, manometer. (Bavendamm.)

${ }^{1}$ Bavendamm, W., Die farblosen und roten Schwefelbakterien des Süss- und Salzwassers. G. Fischer. Jena, 1924.

\section{MEDIA FOR HYDROGEN AND METHANE BACTERIA}

\section{Medium 71}

Potassium Nitrate Solution for Hydrogen Bacteria ${ }^{2}$

Potassium nitrate $\left(\mathrm{KNO}_{3}\right) \ldots \ldots \ldots \ldots \ldots \ldots .2 .0 \mathrm{gm}$.

Mono-sodium phosphate $\left(\mathrm{NaH}_{2} \mathrm{PO}_{4}\right) \ldots \ldots \ldots .0 .5 \mathrm{gm}$.

Magnesium sulphate $\left(\mathrm{MgSO}_{4} \cdot 7 \mathrm{H}_{2} \mathrm{O}\right) \ldots \ldots \ldots \ldots \quad 0.2 \mathrm{gm}$.

Ferric chloride $\left(\mathrm{FeCl}_{3} \cdot 6 \mathrm{H}_{2} \mathrm{O}\right) \ldots \ldots \ldots \ldots \ldots$ trace

Tap water....................... 1,000.0 ce.

${ }^{2}$ Lebedeff, A. E., (Russian). Odessa, 1910.

Cultures grown in an atmosphere of hydrogen containing 5 to 15 per cent carbon dioxide. 


\section{Medium 72}

Ammonidm Chloride Solution for Hydrogen Bacteria ${ }^{1}$

Sodium bicarbonate $\left(\mathrm{NaHCO}_{3}\right)$

$1.0 \mathrm{gm}$.

Ammonium chloride $\left(\mathrm{NH}_{4} \mathrm{Cl}\right)$

$1.0 \mathrm{gm}$.

Monopotassium phosphate $\left(\mathrm{KH}_{2} \mathrm{PO}_{4}\right) \ldots \ldots \ldots$.

$0.5 \mathrm{gm}$.

Ferrous carbonate $\left(\mathrm{FeCO}_{3} \cdot \mathrm{H}_{2} \mathrm{O}\right) \ldots \ldots \ldots \ldots$.

$0.5 \mathrm{gm}$.

Magnesium sulphate $\left(\mathrm{MgSO}_{4} \cdot 7 \mathrm{H}_{2} \mathrm{O}\right) \ldots \ldots \ldots$.

$0.1 \mathrm{gm}$.

Sodium chloride $(\mathrm{NaCl}) \ldots \ldots \ldots \ldots \ldots \ldots \ldots, 0.1 \mathrm{gm}$.

Distilled water.................. 1,000.0 cc.

$\mathrm{pH}=7.1-7.2$.

' Ruhland, W., Jahrb. Wissen. Bot., 63: 321, 1924.

Use freshly prepared $\mathrm{NaHCO}_{3}$. Iron must be added in the form of ferrous carbonate. A sterile solution of the iron salt in water containing $\mathrm{CO}_{2}$ is added to the sterile medium. The culture is grown in an atmosphere containing hydrogen and carbon dioxide.

\section{Medium 73}

Magnesium Ammonium Phosphate Solution for Methane Bacteria ${ }^{2}$

Magnesium ammonium phosphate $\left(\mathrm{MgNH}_{4-}\right.$ $\left.\mathrm{PO}_{4} \cdot 6 \mathrm{H}_{2} \mathrm{O}\right) \ldots \ldots \ldots \ldots \ldots \ldots \ldots \ldots \ldots \ldots \ldots$

Dipotassium phosphate $\left(\mathrm{K}_{2} \mathrm{HPO}_{4}\right) \ldots \ldots \ldots \ldots .0 .05 \mathrm{gm}$.

Calcium sulphate $\left(\mathrm{CaSO}_{4} \cdot 2 \mathrm{H}_{2} \mathrm{O}\right) \ldots \ldots \ldots \ldots .0 .01 \mathrm{gm}$.

Distilled water................. 1,000 cc.

${ }^{2}$ Söhngen, N. L., Bot. Centr., 105 : 371-372, 1907.

The cultures are placed in an atmosphere consisting of 1 part methane $\left(\mathrm{CH}_{4}\right)$ and 2 parts air.

Silica gel or washed agar containing the above nutrients can be conveniently used as solid media.

\section{MEDIA FOR IRON AND MANGANESE OXIDIZING BACTERIA}

\section{Medium 74}

Iron-Ammonium SUlphate Solution ${ }^{3}$

Ammonium sulphate $\left(\left(\mathrm{NH}_{4}\right)_{2} \mathrm{SO}_{4}\right) \ldots \ldots \ldots$

Potassium chloride $(\mathrm{KCl}) \ldots \ldots \ldots \ldots \ldots$

$1.5 \mathrm{gm}$.

Magnesium sulphate $\left(\mathrm{MgSO}_{4} \cdot 7 \mathrm{H}_{2} \mathrm{O}\right) \ldots \ldots \ldots$

$0.05 \mathrm{gm}$.

Dipotassium phosphate $\left(\mathrm{K}_{2} \mathrm{HPO}_{4}\right) \ldots \ldots \ldots$.

$0.05 \mathrm{gm}$.

Calcium nitrate $\left(\mathrm{Ca}\left(\mathrm{NO}_{3}\right)_{2}\right) \ldots \ldots \ldots \ldots \ldots$

$0.05 \mathrm{gm}$.

Distilled water .................................

${ }^{3}$ Lieske, R., Centr. Bakt., II Abt., 49: 413-425, 1919. 
Sterilize in small flasks in layers about 2 centimeters deep. Allow the medium to stand for several days so that it becomes saturated with oxygen and carbon dioxide. After standing, add to each flask about 0.05 grams of sterilized iron dust and inoculate.

\section{Medium 75}

Manganese-ammonium Sulphate Solution

Manganese bicarbonate, saturated solution...... $100.0 \mathrm{cc}$.

Sodium bicarbonate $\left(\mathrm{NaHCO}_{3}\right) \ldots \ldots \ldots \ldots \ldots, 0.1 \mathrm{gm}$.

Ammonium sulphate $\left(\left(\mathrm{NH}_{4}\right)_{2} \mathrm{SO}_{4}\right) \ldots \ldots \ldots \ldots, 0.1 \mathrm{gm}$

Dipotassium phosphate $\left(\mathrm{K}_{2} \mathrm{HPO}_{4}\right) \ldots \ldots \ldots \ldots$ trace

Magnesium sulphate $\left(\mathrm{MgSO}_{4} \cdot 7 \mathrm{H}_{2} \mathrm{O}\right) \ldots \ldots \ldots \ldots$ trace

Tap water.................... 900.0 cc.

The manganese bicarbonate is prepared by saturating a suspension of manganese carbonate with pure carbon dioxide. The medium is sterilized in flowing steam for 25 minutes.

\section{Medium 76}

Ferrous Carbonate and Potassium Acetate Solution Potassium acetate $\left(\mathrm{KC}_{2} \mathrm{H}_{3} \mathrm{O}_{2}\right) \ldots \ldots \ldots \ldots \ldots .0 .5 \mathrm{gm}$. Ferrous carbonate $\left(\mathrm{FeCO}_{3}\right) \ldots \ldots \ldots \ldots \ldots \ldots, 0.5 \mathrm{gm}$. Tap water...................... 1,000.0 cc.

\section{MEDIA FOR NITROGEN FIXING BACTERIA}

\section{Medium 77}

Nitrogen-free Mannitol Solution

Mannitol........................ $10.0 \mathrm{gm}$.

Dipotassium phosphate $\left(\mathrm{K}_{2} \mathrm{HPO}_{4}\right) \ldots \ldots \ldots \ldots .0 .5 \mathrm{gm}$.

Magnesium sulphate $\left(\mathrm{MgSO}_{4} \cdot 7 \mathrm{H}_{2} \mathrm{O}\right) \ldots \ldots \ldots \ldots, 0.2 \mathrm{gm}$.

Sodium chloride $(\mathrm{NaCl}) \ldots \ldots \ldots \ldots \ldots \ldots \ldots .0 .2 \mathrm{gm}$.

Manganese sulphate $\left(\mathrm{MnSO}_{4} \cdot 4 \mathrm{H}_{2} \mathrm{O}\right) \ldots \ldots \ldots$ trace

Ferric chloride $\left(\mathrm{FeCl}_{3} \cdot 6 \mathrm{H}_{2} \mathrm{O}\right) \ldots \ldots \ldots \ldots \ldots$ trace

Distilled water.................... 1,000.0 cc.

For a solid medium add 12.5 to 15 grams of washed agar to each liter. For the isolation of Azotobacter prepare this liquid medium in shallow layers and add sterilized $\mathrm{CaCO}_{3}$ to each flask. 


\section{Medium 78}

Nitrate Mannitol Agar, with and without Indioators

Same as Medium 77 except that 0.5 gram of potassium nitrate $\left(\mathrm{KNO}_{3}\right)$ is added to each liter and an indicator if desired.

IndicAtors.-A. Brom thymol blue medium is prepared as follows: add 5 cubic centimeters of 0.5 per cent alcoholic solution to 1 liter of the medium.

B. Congo Red medium is prepared as follows: add 10 cubic centimeters of a 1 to 400 aqueous solution to 1 liter of the medium.

\section{Medium 79}

Yeast Extract-mannitol Agar

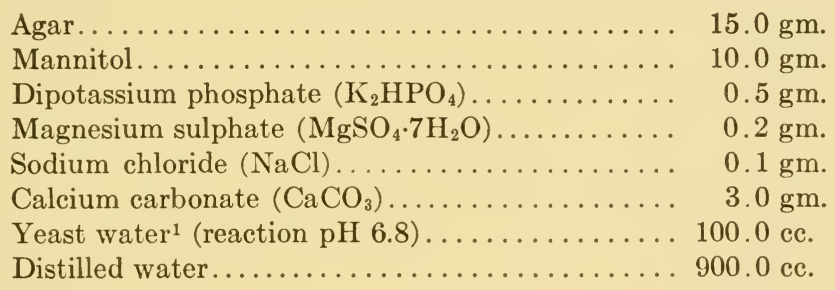

${ }^{1}$ For directions how to make stock yeast extract see Medium 27, page 16.

If this medium is to be used for the isolation of root nodule bacteria add Congo red as given under B in Medium 78.

\section{Medium 80}

\section{Carrot Extract Agar ${ }^{2}$}

Wash the carrots in running water until all soil particles are removed, then chop (with meat chopper) into small pieces and prepare as follows.

Carrots (cut)...................... $250.0 \mathrm{gm}$.

Tap water..................... 500.0 cc.

Cook in a steamer for 30 minutes and filter. Neutralize to $\mathrm{pH} 7.0$ to 7.2 with a strong solution of sodium carbonate and

${ }^{2}$ Stapp, C. und G. Ruschmann, Arb. a. d. Biol. Reich. f. Landw. u. Forst., $13: 314,1925$. 
make up to 500 cubic centimeters. Now add 500 cubic centimeters of 3.6 per cent neutral water solution of agar. Tube and sterilize. Avoid excessive heating because the carrot extract becomes more acid after long heating.

\section{Medium 81}

Pea Extract Sucrose Solution

Pea seedlings 3 to 5 inches tall (net weight)... $300.0 \mathrm{gm}$.

Water......................... 1,000.0 cc.

Heat in the steamer for 4 to 5 hours and then boil for 1 hour over a free flame. Filter and make up to 1,000 cubic centimeters. Add sucrose, 2 per cent, and 0.5 per cent of $\mathrm{CaCO}_{3}$. This medium contains about 50 milligrams of nitrogen in 100 cubic centimeters.

\section{Medium 82}

\section{Navy-bean Seed Extract Sucrose Medium}

Bean seed (dry) ................... $250.0 \mathrm{gm}$.

Tap water.................... 2,500.0 ce.

Soak the beans in the cold water for 2 to 3 hours. Now add water to make 2,500 cubic centimeters and heat in the steamer for 2 hours. Filter and make up to 2,500 cubic centimeters. Add 1 per cent of sucrose and 0.5 per cent of $\mathrm{CaCO}_{3}$. This medium contains about 40 milligrams of nitrogen in 100 cubic centimeters.

\section{Medium 83}

Caffein-bean Extract-glucose for Bacteroid Formation ${ }^{1}$

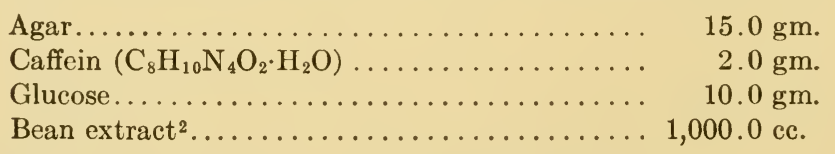

${ }^{1}$ Zippes, H., Centr. Bakt., II Abt., 32 : 107-131, 1911.

${ }^{2}$ Bean extract: Add to 20 grams of powdered navy-bean seed in a mortar 20 cubic centimeters of $N / 1 \mathrm{KOH}$. Allow this to stand a few minutes, then add water sufficient to make 1 liter. This should stand 24 hours. Siphon off the clear liquid, neutralize with phosphoric acid. 
Medium 84

Peptone-sucrose Solution for Gum

\begin{tabular}{|c|c|}
\hline & \\
\hline $\left.\mathrm{PO}_{4}\right) \ldots$ & \\
\hline sulphate $\left(\mathrm{MgSO}_{4} \cdot 7 \mathrm{H}_{2} \mathrm{O}\right)$. & \\
\hline hloride $\left(\mathrm{CaCl}_{2}\right) \ldots$ & \\
\hline & 20. \\
\hline . & 00.0 \\
\hline
\end{tabular}

\section{MEDIA FOR CELLULOSE-DECOMPOSING ORGANISMS} Medium 85

Ammonidm Sulphate-cellulose Soldtion ${ }^{1,2}$

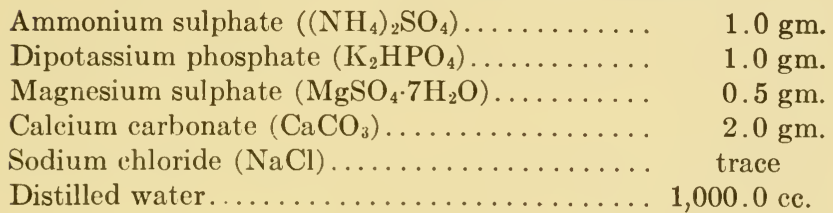

${ }^{1}$ Ammonium chloride $\left(\mathrm{NH}_{4} \mathrm{Cl}\right)$, diammonium phosphate $\left(\left(\mathrm{NH}_{4}\right)_{2} \mathrm{HPO}_{4}\right)$, potassium nitrate $\left(\mathrm{KNO}_{3}\right)$, or sodium nitrate $\left(\mathrm{NaNO}_{3}\right)$ may also be used.

2 Omeliansky, W., Centr. Bakt., II Abt., 8: 226, 1902.

Fill large test tubes about one-third full. Add two or three strips of filter paper to each tube, part of the paper protruding above the surface of the medium. When nitrates are used, the calcium carbonate may be left out.

\section{Medium 86}

\section{Silica-gel Celludose}

Prepare a series of silica-gel plates according to Souleyre method.

\section{Silica Gel according to Souleire ${ }^{3}$}

(Modified)

To 40 cubic centimeters of 20 per cent tartaric acid, 1 cubic centimeter of 60 per cent phosphoric acid and 1 cubic centimeter sulphuric acid (1:1), add 100 cubic centimeters of potassium silicate solution (specific gravity, 1.057). ${ }^{4}$ Let stand until clear, then filter off the clear solution. This is designated as solution $A$.

${ }^{3}$ Souleyre, M., Compt. rend. d. la Soc. Biol., 93: 306, 1925.

${ }^{4} 7.6$ grams potassium silicate made up to 100 -cubic centimeters solution gives specific gravity $=1.057$. 
Solution $B$ is made by mixing two parts of potassium silicate solution (specific gravity, 1.085) ${ }^{1}$ with one part of a 1 per cent $\mathrm{KOH}$ solution. This solution will gel on standing. The alkali solution (1 per cent) should be mixed with the silicate solution to make Solution $B$ only a short time before it is to be used. The solution will keep for about 2 weeks to 1 month.

These two solutions are then titrated against each other with an indicator, which shows the reaction desired.

The solutions can be sterilized. Solution $A$ is sterilized in an autoclave for 10 minutes at $110^{\circ} \mathrm{C}$. Solution $B$, however, will solidify if treated in a like manner. It is necessary, therefore, to put it in a sterile flask and boil for 5 to 10 minutes.

For growth of bacteria, a medium is prepared as follows:

1. 100 cubic centimeters of $A$, and 50 cubic centimeters distilled water.

2. 200 cubic centimeters of nutrient liquid (preferably sterilized longer than the silicate solution).

3. Amount of $B$ required to bring medium to desired reaction. These three solutions are cooled as rapidly as possible after sterilization, and are then poured together. Plates can then be poured without danger of the gel solidifying before pouring is completed. Time required for setting of the gel is 1 to 6 hours.

Five grams of thoroughly ground cellulose is suspended in 100 cubic centimeters of the following solution.

\begin{tabular}{|c|c|}
\hline Diammonium phosphate $\left(\left(\mathrm{NH}_{4}\right)_{2} \mathrm{HPO}_{4}\right) \ldots \ldots$ & $5.0 \mathrm{gm}$. \\
\hline Magnesium sulphate $\left(\mathrm{MgSO}_{4} \cdot 7 \mathrm{H}_{2} \mathrm{O}\right) \ldots$ & $1.0 \mathrm{gm}$. \\
\hline Ferrous sulphate $\left(\mathrm{FeSO}_{4} \cdot 7 \mathrm{H}_{2} \mathrm{O}\right) \ldots$ & $0.02 \mathrm{gm}$. \\
\hline Potassium chloride $(\mathrm{KCl}) \ldots \ldots$ & $1.0 \mathrm{gm}$. \\
\hline Distilled water.......... & $100.0 \mathrm{cc}$. \\
\hline
\end{tabular}

About 2 cubic centimeters of the suspension of the cellulose in the medium is poured upon the surface of each silica plate, in such a manner as to have the cellulose uniformly distributed over the surface; some $\mathrm{CaCO}_{3}$ is then powdered on over the whole surface of each plate. The plates are placed in an incubator at 60 to $65^{\circ} \mathrm{C}$, , until the excess of water has evaporated,

111.6 grams potassium silicate made up to 100 -cubic centimeters solution gives specific gravity $=1.085$. 
without allowing the plate to become dry. The dishes are kept until needed for use.

\section{Medium 87}

Ammonium Sulphate Cellulose Agar ${ }^{1}$

(a) Agar......................... $10.0 \mathrm{gm}$.

Ammonium sulphate $\left(\left(\mathrm{NH}_{4}\right)_{2} \mathrm{SO}_{4}\right) \ldots \ldots \ldots \ldots .2 .0 \mathrm{gm}$.

Dipotassium phosphate $\left(\mathrm{K}_{2} \mathrm{HPO}_{4}\right) \ldots \ldots \ldots \ldots .1 .0 \mathrm{gm}$.

Magnesium sulphate $\left(\mathrm{MgSO}_{4} \cdot 7 \mathrm{H}_{2} \mathrm{O}\right) \ldots \ldots \ldots \ldots, 1.0 \mathrm{gm}$.

Sodium chloride $(\mathrm{NaCl}) \ldots \ldots \ldots \ldots \ldots \ldots . \quad 1.0 \mathrm{gm}$.

Calcium earbonate $\left(\mathrm{CaCO}_{3}\right) \ldots \ldots \ldots \ldots \ldots, 2.0 \mathrm{gm}$.

Tap water..................... 500.0 cc.

(b) Cellulose solution................ 500.0 ce.

${ }^{1}$ McBeth, I. G., Soil Sci., 1: 438, 1916.

1. Pour 1,000 cubic centimeters of ammonium hydroxide, specific gravity 0.90 , into a glass-stoppered bottle; add 250 cubic centimeters of distilled water and 75 grams of pure copper carbonate; shake the solution vigorously until all the copper is dissolved (about 10 to 15 minutes are ordinarily required).

2. To the copper-ammonium solution add 15 grams of highgrade sheet filter paper; shake vigorously at intervals of 10 minutes for $1 / 2$ hour. Examine the solution carefully to see that the paper is completely dissolved. If any particles of paper remain in the solution, the shaking must be continued until the solution is perfectly clear. Dilute 250 cubic centimeters of the ammonium-copper-cellulose solution to 10 liters with tap water; add slowly, with frequent shaking, a weak hydrochloric acid solution prepared by adding 500 cubic centimeters of concentrated acid to 10 liters of tap water. Continue the addition of the acid until the blue color disappears; add a slight excess of acid, shake thoroughly, and allow to stand a few minutes. The finely precipitated cellulose will rise to the top, due to the large quantity of free hydrogen liberated in the precipitation process. Shake the solution vigorously at intervals of a few minutes to dislodge the hydrogen. As soon as the free hydrogen has escaped, the cellulose will settle rapidly.

3. Wash through repeated changes of water until free from copper and chlorine. After the washing is complete, bring the 
cellulose in the solution up to 0.5 per cent by allowing to settle a few days and siphoning off the clear solution or by evaporating. Add the nutrient salts desired, together with 1 per cent of thoroughly washed agar; heat in autoclave or boil until the agar is dissolved; tube and sterilize in the usual way.

\section{Medium 88}

Cellulose-peptone Agar

Agar (washed)

$15.0 \mathrm{gm}$.

Cellulose

$2.5 \mathrm{gm}$.

Peptone

$0.50 \mathrm{gm}$.

Dipotassium phosphate $\left(\mathrm{K}_{2} \mathrm{HPO}_{4}\right)$

$0.2 \mathrm{gm}$.

Magnesium sulphate $\left(\mathrm{MgSO}_{4} \cdot 7 \mathrm{H}_{2} \mathrm{O}\right) \ldots \ldots \ldots$.

$0.2 \mathrm{gm}$.

Potassium carbonate $\left(\mathrm{K}_{2} \mathrm{CO}_{3}\right) \ldots \ldots \ldots \ldots \ldots$

$0.4 \mathrm{gm}$.

Calcium chloride $\left(\mathrm{CaCl}_{2}\right)$ fused $\ldots \ldots \ldots \ldots \ldots$

$0.02 \mathrm{gm}$.

Ferric sulphate $\left(\mathrm{Fe}_{2}\left(\mathrm{SO}_{4}\right)_{3} \cdot 9 \mathrm{H}_{2} \mathrm{O}\right) \ldots \ldots \ldots \ldots$.

$0.02 \mathrm{gm}$.

Sodium chloride $(\mathrm{NaCl}) \ldots \ldots \ldots \ldots \ldots \ldots$.

$0.02 \mathrm{gm}$.

Distilled water. $1,000.0$ cc.

Dissolve the peptone and salts in 100 cubic centimeters of distilled water and filter. Add 400 cubic centimeters of the aqueous cellulose suspension and 500 cubic centimeters of 3 per cent aqueous solution of washed agar (see p. 5).

\section{Medium 89}

Cellulose-peptone Medium for Thermophilic Bacteria ${ }^{1}$

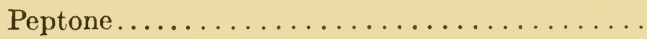

Calcium carbonate $\left(\mathrm{CaCO}_{3}\right) \ldots \ldots \ldots \ldots \ldots$

Sodium ammonium phosphate $\left(\mathrm{Na}\left(\mathrm{NH}_{4}\right) \mathrm{HPO}_{4} \cdot-\right.$ $\left.4 \mathrm{H}_{2} \mathrm{O}\right)$. $5.0 \mathrm{gm}$. excess

Monopotassium phosphate $\left(\mathrm{KH}_{2} \mathrm{PO}_{4}\right) \ldots \ldots \ldots$.

Magnesium sulphate $\left(\mathrm{MgSO}_{4} \cdot 7 \mathrm{H}_{2} \mathrm{O}\right) \ldots \ldots \ldots$.

Calcium chloride $\left(\mathrm{CaCl}_{2}\right) \ldots \ldots \ldots \ldots \ldots \ldots$

Ferric chloride $\left(\mathrm{FeCl}_{3} \cdot 6 \mathrm{H}_{2} \mathrm{O}\right) \ldots \ldots \ldots \ldots$ trace

Water........................... 1,000.0 ce.

1 Viljoen, J. A., E. B. Fred, and W. H. Peterson, J. Agr. Sci., 16: 1, 1926.

Reaction about $\mathrm{pH}$ 7.4. Add about 0.3 gram of paper pulp or of cut up filter paper to 20 cubic centimeters of liquid in long test tubes. 


\section{MISCELLANEOUS MEDIA}

\section{Medium 90}

\section{Litmus or Brom Cresol Purple Milk}

Litmus milk is one of the most important culture solutions. Because of the great variety of organisms which grow in it, and the decided changes which they produce, litmus milk is very useful in the classification of bacteria. All organisms should be inoculated into litmus milk and the changes after various periods of time recorded. To secure the best results prepare as follows:

Fresh milk, immediately after milking, should be centrifuged and this fat-free milk taken directly to the laboratory. Pipette 5 - or 10-cubic centimeter portions of the fresh milk into previously sterilized test tubes, plug with cotton, and sterilize for 10 minutes in the autoclave at 8 to 10 pounds' pressure. Cool in water and repeat sterilization 24 hours later. After the last sterilization incubate the tubes for a week or more at 28 to $30^{\circ} \mathrm{C}$. and note if there are changes. Now add to each tube of the bacteria free milk about 2 to 3 drops of a sterilized saturated solution of high-grade lime-free blue litmus (litmus 1 gram and water, 15 cubic centimeters). Litmus milk should give a lavender color, not too deep, which turns red in the presence of acids and blue in the presence of alkalies.

Brom cresol purple may be used in place of litmus. For this purpose, prepare a stock solution as follows: $0.5 \mathrm{gm}$. of brom-cresol purple should be ground in a mortar with 14 cubic centimeters of $N / 10$ sodium hydroxide and made up to 100 cubic centimeters with distilled water. Take 10 cubic centimeters of this 0.5 per cent solution to 1,000 cubic centimeters of milk or about 2 to 3 drops to 10 cubic centimeters of milk.

\section{Medium 91}

\section{Ротато}

Select large potatoes, wash and scrub well with a stiff brush. Peel and cut in wedge-shaped blocks about 4 to 6 centimeters long and 1.5 centimeters wide. The size will depend upon the 
test tubes. Allow the cut potatoes to stand in running water for at least 12 hours.

Place a small piece of glass rod or cotton in the bottom of the test tube and insert the potato wedge into the tube. Fill the tube with water until the potato is entirely under the liquid. Plug and sterilize: about 15 minutes at 10 pounds' steam pressure for 3 consecutive days will usually be found sufficient. Just before use, pour off the excess water.

Potatoes prepared in this way should retain their white color.

\section{Medium 92}

Mannitol Glycero-phosphate Solution

Mannitol...................... $10.0 \mathrm{gm}$.

Potassium nitrate $\left(\mathrm{KNO}_{3}\right) \ldots \ldots \ldots \ldots \ldots \ldots, 0.5 \mathrm{gm}$.

Magnesium sulphate $\left(\mathrm{MgSO}_{4} \cdot 7 \mathrm{H}_{2} \mathrm{O}\right) \ldots \ldots \ldots \ldots, 0.2 \mathrm{gm}$.

Sodium chloride $(\mathrm{NaCl}) \ldots \ldots \ldots \ldots \ldots \ldots . .6 .2 \mathrm{gm}$.

Calcium glycero-phosphate............ $1.0 \mathrm{gm}$.

Water........................ 1,000.0 cc.

Adjust reaction to $\mathrm{pH} 6.5$ to 7.0 .

Medium 93

Peptone-sucrose-Lactose Solution

Sucrose

$10.0 \mathrm{gm}$.

Peptone $20.0 \mathrm{gm}$.

Lactose $10.0 \mathrm{gm}$.

Sodium chloride $(\mathrm{NaCl})$

$2.0 \mathrm{gm}$.

Dipotassium phosphate $\left(\mathrm{K}_{2} \mathrm{HPO}_{4}\right) \ldots \ldots \ldots \ldots$

$2.0 \mathrm{gm}$.

Magnesium sulphate $\left(\mathrm{MgSO}_{4} \cdot 7 \mathrm{H}_{2} \mathrm{O}\right) \ldots \ldots \ldots \ldots, 1.0 \mathrm{gm}$.

Tap water..................... 1,000.0 cc.

\section{Medium 94}

Peptone-sodium Phosphate Solution

Peptone...................... $10.0 \mathrm{gm}$.

Disodium phosphate $\left(\mathrm{Na}_{2} \mathrm{HPO}_{4} \cdot 2 \mathrm{H}_{2} \mathrm{O}\right)^{1} \ldots \ldots . \quad 5.0 \mathrm{gm}$.

Carbohydrate.................. $10.0 \mathrm{gm}$.

Tap water..................... 1,000.0 ce.

${ }^{1}$ To prepare disodium phosphate $\left(\mathrm{Na}_{2} \mathrm{HPO}_{4} \cdot 2 \mathrm{H}_{2} \mathrm{O}\right)$ take ordinary disodium phosphate with $12 \mathrm{H}_{2} \mathrm{O}$ and spread it out on filter paper and allow it to remain at room temperature in a dry place for 2 weeks. 


\section{Reaction $\mathrm{pH} 7.1$ to 7.2 .}

Media 92, 93, 94 are recommended for lactic acid-forming bacteria of milk and milk products.

\section{Medium 95}

\section{Malt Extract-peptone Solution}

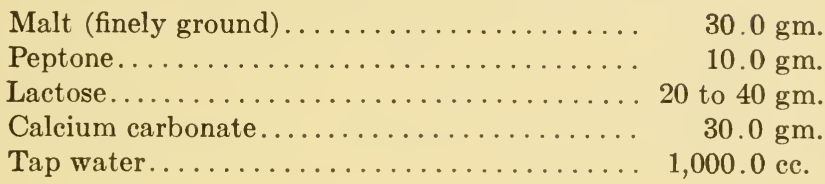

The malt is extracted in the water by boiling for 1 hour; the other constituents are then added.

\section{Medium 96}

Paraffin Agar for Hydrocarbon-destroying Organisms ${ }^{1}$

Ammonium chloride $\left(\mathrm{NH}_{4} \mathrm{Cl}\right) \ldots \ldots \ldots \ldots \ldots \ldots, 0.5 \mathrm{gm}$.

Dipotassium phosphate $\left(\mathrm{K}_{2} \mathrm{HPO}_{4}\right) \ldots \ldots \ldots \ldots .0 .5 \mathrm{gm}$.

Magnesium sulphate $\left(\mathrm{MgSO}_{4} \cdot 7 \mathrm{H}_{2} \mathrm{O}\right) \ldots \ldots \ldots \ldots .0 .5 \mathrm{gm}$.

Paraffin oil.................. $10.0 \mathrm{gm}$.

Agar........................ $20.0 \mathrm{gm}$.

Distilled water.................... 1,000.0 cc.

${ }^{1}$ Söhngen, N. L., Centr. Bakt., II Abt., 37 : 595-609, 1913.

\section{Medium 97}

Solution for Fat Decomposition 2

Dipotassium phosphate $\left(\mathrm{K}_{2} \mathrm{HPO}_{4}\right) \ldots \ldots \ldots \ldots$

$5.0 \mathrm{gm}$.

Ammonium phosphate $\left.\left(\mathrm{NH}_{4}\right)_{3} \mathrm{PO}_{4}\right) \ldots \ldots \ldots$.

Magnesium sulphate $\left(\mathrm{MgSO}_{4} \cdot 7 \mathrm{H}_{2} \mathrm{O}\right) \ldots \ldots \ldots$

$5.0 \mathrm{gm}$.

Calcium chloride $\left(\mathrm{CaCl}_{2}\right) \ldots \ldots \ldots \ldots \ldots \ldots$

$1.0 \mathrm{gm}$.

Ferric chloride $\left(\mathrm{FeCl}_{3} \cdot 6 \mathrm{H}_{2} \mathrm{O}\right) \ldots \ldots \ldots \ldots \ldots$ trace

Sodium chloride $(\mathrm{NaCl}) \ldots \ldots \ldots \ldots \ldots$ trace

Distilled water..................... 1,000.0 cc.

${ }^{2}$ Rahn, O., Centr. Bakt., II Abt., $15: 423,1906$.

Molten fat is placed in a flask and, on inclining the flask, the fat is allowed to solidify. The above nutrient solution is then added. Three-tenth to five-tenth per cent of finely powdered fat may also be used with the above solution. 


\section{Medium 98}

\section{Peptone-beef Extract Gelatin Agar ${ }^{1}$}

(a) Sodium chloride $(\mathrm{NaCl}) \ldots \ldots \ldots \ldots \ldots \ldots .5 .0 \mathrm{gm}$.

Monopotassium phosphate $\left(\mathrm{KH}_{2} \mathrm{PO}_{4}\right) \ldots \ldots .0 .5 \mathrm{gm}$.

Dipotassium phosphate $\left(\mathrm{K}_{2} \mathrm{HPO}_{4}\right) \ldots \ldots \ldots . \quad 1.5 \mathrm{gm}$.

Water....................... 100.0 ec.

(b) Gelatin.................. $4.0 \mathrm{gm}$.

Glucose...................... $0.05 \mathrm{gm}$.

Peptone.................... $0.1 \mathrm{gm}$.

Beef infusion................... 5.0 cc.

Water..................... 400.0 ec.

${ }^{1}$ Frazier, W. C., J. Inf. Dis., 39: 302, 1926.

Pour $(a)$ and $(b)$ together, heat in flowing steam and mix with 500 cubic centimeters of a 3 per cent agar (washed) solution.

Adjust $\mathrm{pH}$ to 7.0.

Pour duplicate plates and inoculate in the center. After 48 hours or longer at $30^{\circ} \mathrm{C}$. make tests.

Flood one plate with 1 per cent tannic acid and the duplicate with acid $\mathrm{HgCl}_{2}$ solution. ${ }^{2}$

${ }^{2} \mathrm{HgCl}_{2} 15$ grams, $\mathrm{HCl}$ (Conc) 20 cubic centimeters, and 100 cubic centimeters of water.

If the gelatin has been changed, a clear zone will appear about the giant colony in the plate to which $\mathrm{HgCl}_{2}$ has been added. This requires 15 to 30 minutes.

The tannic acid plate will show the amount of decomposition of the gelatin.

\section{Medium 99}

Casein Hydrolysis on Milk Agar

(a) Agar..................... $15.0 \mathrm{gm}$.

Water....................... 500.0 ce.

(b) Milk.................. 500.0 ce.

Tube separately in portions for plating. Sterilize. Cool to $45^{\circ} \mathrm{C}$. and pour plates using one tube of each per plate.

Streak the culture to be tested on the surface of the milk agar.

After incubation examine the plates for clearing along line of growth. Flood plates with dilute acid ( $\mathrm{HCl} \mathrm{1:10).} \mathrm{If} \mathrm{clearing}$ remains, it denotes true hydrolysis of casein. If not, it is weak acid clearing. 


\section{Medium 100}

Sodium Citrate for the Colon Aerogenes Grodp ${ }^{1}$

Sodium chloride $(\mathrm{NaCl}) \ldots \ldots \ldots \ldots \ldots \ldots . \quad 5.0 \mathrm{gm}$.

Magnesium sulphate $\left(\mathrm{MgSO}_{4} \cdot 7 \mathrm{H}_{2} \mathrm{O}\right) \ldots \ldots \ldots .0 .2 \mathrm{gm}$.

Monoammonium phosphate $\left(\mathrm{NH}_{4} \mathrm{H}_{2} \cdot \mathrm{PO}_{4}\right) \ldots . \quad 1.0 \mathrm{gm}$.

Dipotassium phosphate $\left(\mathrm{K}_{2} \mathrm{HPO}_{4}\right) \ldots \ldots \ldots \ldots . \quad 1.0 \mathrm{gm}$.

Sodium citrate $\left(5 \frac{1}{2} \mathrm{H}_{2} \mathrm{O}\right) \ldots \ldots \ldots \ldots \ldots \ldots .2 .77 \mathrm{gm}$.

Distilled water................... 1,000.0 ce.

${ }^{1}$ Koser, S. A., J. Bact., 9: 63, 1924.

Bacterium coli of fecal origin is unable to utilize citrate, while the $B$. aerogenes-cloacae types all utilize citrate.

\section{Medium 101}

Ferric Ammonium Citrate-nitrate Solution
Ammonium sulphate $\left(\left(\mathrm{NH}_{4}\right)_{2} \mathrm{SO}_{4}\right) \ldots \ldots \ldots \ldots$
$0.5 \mathrm{gm}$.
Sodium nitrate $\left(\mathrm{NaNO}_{3}\right) \ldots \ldots \ldots \ldots \ldots \ldots$
$0.5 \mathrm{gm}$.
Dipotassium phosphate $\left(\mathrm{K}_{2} \mathrm{HPO}_{4}\right) \ldots \ldots \ldots \ldots$.
$0.5 \mathrm{gm}$.
Magnesium sulphate $\left(\mathrm{MgSO}_{4} \cdot 7 \mathrm{H}_{2} \mathrm{O}\right) \ldots \ldots \ldots$
$0.5 \mathrm{gm}$.
Calcium chloride $\left(\mathrm{CaCl}_{2}\right) \ldots \ldots \ldots \ldots \ldots \ldots$
$0.2 \mathrm{gm}$.
Ferric ammonium citrate............ $10.0 \mathrm{gm}$.
Distilled water................... 1,000.0 ce.

The ferric ammonium citrate should be sterilized separately and added to the salt solution when cool. If a solid medium is wanted, add 1.5 per cent of agar.

The decomposition of the organic radical is accompanied by the precipitation of the jron; thus in an agar medium brown zones are formed around the colonies.

\section{Medium 102}

CORN MASH

Corn meal (not degerminated).......... 50 to $80 \mathrm{gm}$.

Tap water....................... 1,000 cc.

Mix the corn meal with cold water. Steam for 2 to 3 hours and tube in long test tubes. Sterilize for 2 hours at $120^{\circ} \mathrm{C}$.

\section{Medium 103}

Sheep- or Beef-brain for ANaerobio Bacteria

1. Boil sheep brain with equal volume of water.

2. Decant water (save) and press brain through a potato ricer. 
3. Add decanted water, 2 per cent peptone and 0.1 per cent glucose.

4. Tube by punching through the filling funnel with a glass rod.

5. Sterilize intermittently in an Arnold sterilizer.

Five daily runs of 30 minutes each are recommended. Sterilization in an autoclave is usually a failure because of the tendency of the medium to climb on to the plugs. However, if long tubes are used, this medium may be sterilized in the autoclave. The finished medium is nearly white with a clear supernatant liquid.

The small amount of glucose is to stimulate growth; excess would prevent or interfere with putrefaction and blackening. Peptone stimulates early development and intensifies the blackening produced by those organisms liberating $\mathrm{H}_{2} \mathrm{~S}$.

\section{Medium 104}

Nitrate Solution for Higher Green Plants

(a) Calcium nitrate $\left(\mathrm{Ca}\left(\mathrm{NO}_{3}\right)_{2} \cdot 4 \mathrm{H}_{2} \mathrm{O}\right) \ldots \ldots \ldots \ldots, 100.0 \mathrm{gm}$. Potassium nitrate $\left(\mathrm{KNO}_{3}\right) \ldots \ldots \ldots \ldots \ldots \ldots .25 .0 \mathrm{gm}$.

Sodium chloride $(\mathrm{NaCl}) \ldots \ldots \ldots \ldots \ldots \ldots, 15.0 \mathrm{gm}$.

Distilled water.................. 1,000.0 cc.

(b) Monopotassium phosphate $\left(\mathrm{KH}_{2} \mathrm{PO}_{4}\right) \ldots \ldots .25 .0 \mathrm{gm}$.

Distilled water................. 1,000.0 ec.

(c) Magnesium sulphate $\left(\mathrm{MgSO}_{4} \cdot 7 \mathrm{H}_{2} \mathrm{O}\right) \ldots \ldots \ldots, \quad 50.0 \mathrm{gm}$.

Distilled water..................

(d) Ferric chloride $\left(\mathrm{FeCl}_{3} \cdot 6 \mathrm{H}_{2} \mathrm{O}\right) \ldots \ldots \ldots \ldots \ldots, \quad 5.0 \mathrm{gm}$.

Distilled water................. 250.0 ec.

Take 10 cubic centimeter portions of solutions $(a),(b)$, and (c) to 1,000 cubic centimeters of water. Add 1 to 2 drops of solution $(d)$.

\section{Medium 105}

Solution for Growing Higher Plants

(a) Ammonium nitrate $\left(\mathrm{NH}_{4} \mathrm{NO}_{3}\right) \ldots \ldots \ldots \ldots, 32.0 \mathrm{gm}$.

Distilled water................. $1,000.0$ cc.

(b) Monocalcium phosphate $\left(\mathrm{CaH}_{4}\left(\mathrm{PO}_{4}\right)_{2} \cdot \mathrm{H}_{2} \mathrm{O}\right) .10 .0 \mathrm{gm}$. Distilled water................. 1,000.0 ce.

(c) Potassium sulphate $\left(\mathrm{K}_{2} \mathrm{SO}_{4}\right) \ldots \ldots \ldots \ldots, 20.0 \mathrm{gm}$. Distilled water................ 1,000.0 cc.

(d) Magnesium sulphate $\left(\mathrm{MgSO}_{4} \cdot 7 \mathrm{H}_{2} \mathrm{O}\right) \ldots \ldots \ldots \quad 8.0 \mathrm{gm}$. Distilled water. . . . . . . .

(e) Ferric chloride $\left(\mathrm{FeCl}_{3} \cdot 6 \mathrm{H}_{2} \mathrm{O}\right) \ldots \ldots \ldots \ldots \ldots, 0.1 \mathrm{gm}$. Distilled water................ 250.0 ce. 
Prepared with ammonia-free water and chemically pure salts.

Dilute 10-cubic centimeter poritons of $(a),(b),(c)$, and $(d)$ and 1 cubic centimeter of $(e)$ in 1,000 cubic centimeters of water. If a nitrogen-free medium is desired, omit (a). Plant food solutions should be renewed at regular intervals of about one week each.

\section{Medium 106}

Modified Crone's Nitrogen-free Solution ${ }^{1}$

Stock Salt Mixture:

Potassium chloride $(\mathrm{KCl}) \ldots \ldots \ldots \ldots \ldots \ldots, 10.0 \mathrm{gm}$.

Calcium sulphate $\left(\mathrm{CaSO}_{4} \cdot 2 \mathrm{H}_{2} \mathrm{O}\right) \ldots \ldots \ldots \ldots \ldots 2.5 \mathrm{gm}$.

Magnesium sulphate $\left(\mathrm{MgSO}_{4} \cdot 7 \mathrm{H}_{2} \mathrm{O}\right) \ldots \ldots \ldots \ldots 2.5 \mathrm{gm}$.

Tricalcium phosphate $\left(\mathrm{Ca}_{3}\left(\mathrm{PO}_{4}\right)_{2}\right) \ldots \ldots \ldots \ldots 2.5 \mathrm{gm}$.

Ferric phosphate $\left(\mathrm{FePO}_{4}\right) \ldots \ldots \ldots \ldots \ldots \ldots .2 .5 \mathrm{gm}$.

${ }^{1}$ Bryan, O. C., Soil. Sci., 13, 279, 1922.

Mix all of these salts and grind to a fine powder.

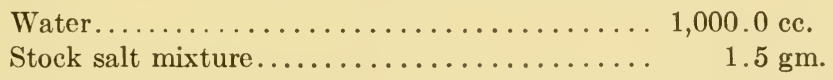

If a solid medium is wanted, take 7.5 grams of washed agar to 1 liter. After sterilization, shake until salts are well mixed with agar and allow to harden.

\section{Medium 107}

\section{Preserving Stock Coltures in Soll}

Mix equal parts of a fertile soil of neutral reaction with sand. Fill into test tubes, about 2-inch layers and sterilize without cotton plugs for 5 to 6 hours at $120^{\circ} \mathrm{C}$. Now add sterilized water to bring the moisture of the soil to about two-thirds saturation and plug tubes with cotton. Again sterilize for 2 hours. Add to a few of the tubes, glucose nutrient broth and incubate for at least a week. If there are no signs of growth, the soil tubes are ready for use. To prevent mold growth, through plugs, store these tubes in a dry place.

\section{Medium 108}

Preserving Stock Cultures in Corn Mash

Same as Medium 102. This medium will be found useful for cultures of lactic-acid-forming bacteria. 
Medium 109

Preserving Stock Cultures in Meat Infusion, Peptone, Gelatin Phosphate Agar ${ }^{1}$

Medium 110

Preservation of Stock Cultures in Vacuo ${ }^{2}$

111

Preserving Plate Cultures

Washed agar................... $20.0 \mathrm{gm}$.

Glycerol $\left(\mathrm{C}_{3} \mathrm{H}_{5}(\mathrm{OH})_{3}\right) \ldots \ldots \ldots \ldots \ldots \ldots \ldots \ldots \ldots \ldots \ldots$ cc.

Distilled water.................. 500.0 cc.

Dissolve the agar in the water by heating in a steamer, add the glycerol, and filter through glass wool.

\section{FAVORABLE CONDITIONS FOR THE DEVELOPMENT OF ANAEROBIC BACTERIA}

\section{Living Vegetable Tissue}

To an ordinary desiccator or a museum jar with tightly fitting cover add finely chopped raw potato, carrots, lettuce or similar vegetable tissue. If potato is used, about 50 grams per liter of air will be found satisfactory. Now add the tubes or plate cultures of bacteria and seal the jar. The respiring plant tissue rapidly absorbs the free oxygen and gives off $\mathrm{CO}_{2}$ thus bringing about favorable conditions for the growth of anaerobic bacteria.

Sterile milk plus a small amount of methylene blue may be used as an indicator for anaerobiosis.

\section{Pyrogallic Acid for Absorbing Oxygen}

For every 100 cubic centimeters of air space take 1 gram of pyrogallic acid and 10 cubic centimeters of a 10 per cent solution of sodium or potassium hydroxide.

Note.-To prepare an anaerobic jar, cover the bottom of the jar with $1 / 2$-inch layer of pyrogallic acid. Fit the cover tightly to the jar with vaseline and remove the air with a suction pump, and when there is a good vacuum, run in 75 to 100 cubic centimeters alkali solution.

${ }^{1}$ Ayres, S. H., and W. T. Johnson, J. Bact., 9 : 112, 1924.

${ }^{2}$ Brown, J. H., Science, 64: 429, 1926. 


\section{PART II}

\section{METHODS OF STAINING OF BACTERIA}

The general structure of bacteria and other microorganisms is most easily seen in stained preparations. The process of staining consists in smearing a suspension of the organisms over a clean slide, drying at room temperature, fixing to the glass by passing through a flame two or three times (do not burn) and staining the film by one of the methods outlined below. After staining, the film is washed in running water, dried with a blotter, and examined. To preserve the mount, a small drop of balsam is placed over the film and the cover glass is pressed down gently to force out the excess of balsam. Set the slide in a warm place to dry.

Some of the most important laboratory stains are (1) methylene blue or thionin, (2) crystal violet, (3) fuchsin, (4) erythrosin, and (5) nigrosin. Stock solutions of methylene blue, thionin, crystal violet, and fuchsin should be prepared and kept on hand. For the stocks, make a saturated solution of the dyes in 95 per cent ethyl alcohol. Filter through paper a small amount of the dye and dilute as given in the directions.

For quick preparations, not deeply stained, the methylene blue will be found satisfactory. Fuchsin, on the other hand, possesses unusual penetrating power for staining bacterial cells and spores and will be found useful for a great many kinds of bacteria. If heated these dyes penetrate much more rapidly and thus give more deeply stained mounts.

\section{Loeffler's Alkaline-Methylene Blue}

Saturated alcoholic solution of methylene blue..... 30.0 ce. Solution of potassium hydroxide in distilled water $(1: 10,000) \ldots \ldots \ldots \ldots \ldots \ldots \ldots \ldots \ldots \ldots \ldots \ldots \ldots \ldots, 100.0$ s.c.

\section{Ziehl's Carbol-Fuchsin}

Saturated alcoholic solution of basic fuchsin...... 10.0 cc.

Carbolic acid, 5 per cent aqueous solution........ $100.0 \mathrm{ec}$. 
If used in staining root-nodule bacteria dilute the carbol fuchsin 1 part of stain to 9 parts of distilled water.

\section{Gram Stain}

This is one of the most important methods of staining employed in a study of bacteria. It is commonly used to distinguish certain organisms from others and also to show the general morphology. It has been found that when stained with gentian or crystal violet, and treated with an iodine solution, some organisms are easily decolorized while others are much more difficult to decolorize. The method follows. Prepare a thin smear of the culture on a slide. Dry in the air and fix with heat. Stain 1 minute with the crystal violet dye and then treat with the iodine solution for 1 minute.

\section{Crystal Violet}

Saturated alcoholic solution of crystal violet........ 10.0 cc. Ammonium oxalate, 1 per cent aqueous solution..... $40.0 \mathrm{cc}$.

\section{Lugol's Iodine Solution}

Iodine $1.0 \mathrm{gm}$.

Potassium iodide $2.0 \mathrm{gm}$.

Water.......................... 300.0 cc.

Decolorize for 30 seconds in 95 per cent alcohol. Wash between each step. Counter stain for 10 seconds with safranin. Wash and dry.

\section{Safranin}

Saturated alcoholic solution of safranin......... 10.0 cc.

Distilled water..................... 100.0 cc.

If gram-positive, the cells should retain the crystal violet stain and thus appear under the microscope as a deep violet. If gram-negative, the cells are decolorized by the alcohol and thus show a pale pink color.

\section{Carbol Thionin (Nicolle's)}

Prepare a stock saturated alcoholic solution of thionin in 50 per cent alcohol.

Take 10 cubic centimeters of this saturated solution of thionin and 100 cubic centimeters of a 2 per cent carbolic acid solution. 
This is an excellent bacterial stain.

\section{ERYTHRosin ${ }^{1}$}

(a) Erythrosin...................... $5.0 \mathrm{gm}$.

Alcohol $(70$ per cent) $\ldots \ldots \ldots \ldots \ldots \ldots \ldots 100.0$ cc.

(b) Erythrosin.................... $1.0 \mathrm{gm}$

Carbolic acid $(5$ per cent $) \ldots \ldots \ldots \ldots \ldots \ldots, 100.0$ cc.

This stain is especially recommended for root-nodule bacteria.

1. Place a drop of the fresh culture on a glass slide, tilt the slide to allow drop to spread. Dry the film in an oven at $45^{\circ} \mathrm{C}$. and fix in absolute alcohol.

2. After the alcohol evaporates, flood the mount with $(a)$ and allow to stain for 10 minutes.

3 . If the stain is not deep enough, wash off this alcohol erythrosin and again stain with $(b)$ for 10 minutes.

${ }^{1}$ Winogradsky, S. Ann. Inst. Pasteur, 39: 325, 1925; Gangulee, N. Ann. Appl. Biol., 13: 364, 1926.

\section{Capsule Stain Adapted from Dorner Spore Stain}

1. Spread a loopful of culture on clean glass slide. Air dry and do not fix.

2. Stain 1 to 2 minutes with cold carbol fuchsin. Wash gently in water.

3. Cover with thin layer of nigrosin by spreading a loopful of saturated aqueous solution of nigrosin. Dry quickly to prevent decolorization of the cells.

Cells will be red and capsules white against a blue-gray background.

\section{Capsule Stain. Negative Method with Ink}

Place a loopful of liquid culture on a clean glass slide. Add to it a loopful of ink (small loop carrying about one-fourth as much liquid). Cover with a cover slip and examine as a wet mount. The bacteria will be white against a gray background; their capsules will be unstained and appear as halos around the denser bacterial cells.

By this method one can demonstrate some capsules which cannot be stained by any positive staining method.

The ink to be used is Burri's Pelikan Tusche, No. 541 (Grübler). It is bacteria free when received and must be kept aseptically. 
Ordinary India ink cannot be used because of the bacteria which it contains.

\section{Spore Stain (Dorner Modified)}

1. Spread a loopful of culture, suspension or liquid culture, on a clean glass slide; dry and fix by heat.

2. Cover with Ziehl's carbol fuchsin. Steam over water bath for 10 to 20 minutes. Do not allow fuchsin to dry on smear. Add more fuchsin if needed. Wash in water.

3. Spread thinly over the smear a loopful of saturated aqueous nigrosin solution. Spread either with wire loop or with a glass slide as for blood smears. If the nigrosin is not well spread the first time it may be washed off with water and more nigrosin applied.

4. Dry without heating and examine in oil, or mount in Canada balsam.

\section{Spore Stain (Lagerberg's Modified)}

1. Make film, fix by heat, and cover with small amount of 5 per cent chromic acid.

2. After 30 seconds, add about twice as much concentrated ammonia as there is chromic acid on the slide. Allow to act about 2 minutes.

3. Rinse with tap water and steam with carbol fuchsin for 2 or 3 minutes.

4. Rinse and destain with 1 per cent sulphuric acid for 15 to 30 seconds.

5. Rinse again and flood slide with the tap water.

6. Add to this a few drops of Loeffler's methylene blue and allow to stain for 10 to 30 seconds.

7. Rinse, blot, dry, and examine.

\section{Nigrosin for Negative Mounts}

1. Place a loopful of culture on a clean glass slide, spread, and allow it to air dry.

2. Spread thinly over the smear a loopful of saturated aqueous nigrosin solution. Spread either with the wire loop or with a glass slide (as for blood smears). Dry and examine in oil, or mount in Canada balsam. 
By the use of nigrosin it is possible to examine organisms unstained. There are many points in favor of this method, e.g., the organisms do not shrink or change their form. Nigrosin may be used in demonstrating the motility of bacteria. For this purpose add a very small amount of nigrosin to a hanging drop.

\section{Congo Red for Negative Mounts}

(For differentiating living and dead bacteria)

1. Place a drop of 2 per cent aqueous Congo red solution (free from bacteria) on a clean glass slide.

2. Mix with it a loopful of the bacterial culture.

3. Allow it to dry thoroughly in air 10 minutes or more.

4. Flood with acid alcohol ( 1 or 2 per cent $\mathrm{HCl}$ ). This changes the color to blue and fixes the film.

5. Dry without washing and examine in oil, with or without cover glass. Living cells appear unstained-white against blue.

Unless preserved with oil or balsam the preparations fade rapidly.

This method of preparing negative mounts is recommended for root-nodule bacteria. The active living cells are negative while the dead cells are more or less positive.

\section{Erythrosin for Direct Staining of Soil Bacteria}

1. Prepare a suspension of soil (about $1: 10$ ) in a 0.015 per cent solution of gelatin.

2. Smear a thin film on a slide and dry.

3. Immerse in 40 per cent acetic acid for 1 to 3 minutes, wash and dry on a water bath.

4. While on the water bath, stain for 1 minute with 1 per cent aqueous solution of erythrosin $\mathrm{Y}$ or rose bengal.

Barlow Stain for Root Nodule Bacteria

(See p. 109) 


\section{PART III}

\section{QUALITATIVE AND QUANTITATIVE METHODS OF ANALYSIS}

\section{PREPARATION OF REAGENTS}

Prepare stock solutions of the indicators in dropping bottles.

Phenolphthalein.-Dissolve 1 gram of pure phenolphthalein in 100 cubic centimeters of 86 per cent alcohol. This indicator is recommended for the titration of organic and inorganic acids and strong bases. It should not be used for the titration of ammonia.

Methyl Orange.-Dissolve 0.02 gram of solid methyl orange in 100 cubic centimeters of hot water, allow to cool, and, if a deposit forms, filter. If the sodium salt is used instead of the acid, take 0.022 gram to 100 cubic centimeters of water. Add 0.67 cubic centimeters of $0.1 \mathrm{~N}$ hydrochloric acid, let stand, and filter. Methyl orange is used for the titration of strong acids.

Litmus.-This indicator is obtained from a species of lichen. It is widely used in bacteriology, especially in milk. The chief coloring principle is azolitmin. Dissolve 5 grams of purified litmus in 100 cubic centimeters of water. Heat in the steamer for 1 to 2 hours, with occasional shaking. Allow to settle for several days and then decant the clear liquid.

Cochineal.-Take 6 grams of cochineal to 50 cubic centimeters of alcohol (95 per cent) and 200 cubic centimeters of distilled water. Shake the cochineal in the mixture of water and alcohol. Allow to stand for two days at room temperature. Filter until clear. The color of this solution should be a deep ruby red; in the presence of alkali a violet color, and in the presence of acid a yellowish-red color.

Sodium Alizarine Sulfonate.-Dissolve 1 gram in 100 cubic centimeters of distilled water by warming. Filter and make up to volume. 
A list of the color change and $\mathrm{pH}$ range of some of the more common indicators is given below.

The indicators for measuring the hydrogen-ion concentration are prepared as follows: 0.1 gram of the dry powder is ground in a mortar with varying amounts of $N / 20 \mathrm{NaOH}$ and diluted to 25 cubic centimeters with water.

0.1 Gram of Indicator

$N / 20 \mathrm{NaOH}$

Used, Cubic

Centimeters

Phenol red.......................... 5.7

Brom phenol blue.................... 3.0

Cresol red.......................... 5.3

Brom cresol purple.................... 3.7

Thymol blue....................... 4.3

Brom thymol blue...................... 3.2

Methyl red...................... 7.4

For colorimetric tests, dilute the stock solution of 25 cubic centimeters with distilled water to 250 cubic centimeters or a concentration of 0.04 per cent of the indicator. Take 5 drops of this dilute solution to 10 cubic centimeters of the liquid to be tested.

Color Change and pH Range of Certain Indicators

\begin{tabular}{|c|c|c|}
\hline Common name & Color change & Range $\mathrm{pH}$ \\
\hline Thymol blue (acid). & Red-yellow & 1.2 to 2.8 \\
\hline Brom phenol blue........ & Yellow-blue & 3.0 to 4.6 \\
\hline Brom cresol green........ & Yellow-green & 4.0 to 5.6 \\
\hline Methyl red......... & Red-yellow & 4.4 to 6.0 \\
\hline Brom cresol purple.. & Yellow-purple & 5.2 to 6.8 \\
\hline Chlor phenol red.... & Yellow-red & 5.2 to 6.8 \\
\hline Brom thymol blue.. & Yellow-blue & 6.0 to 7.6 \\
\hline Phenol red........ & Yellow-red & 6.8 to 8.4 \\
\hline Cresol red.... & Yellow-red & 7.2 to 8.8 \\
\hline Thymol blue (alkaline). & Yellow-blue & 8.0 to 9.6 \\
\hline Phenolphthalein... & Colorless-red & 8.3 to 10.0 \\
\hline Methyl orange... & Orange red-yellow & 3.1 to 4.4 \\
\hline Litmus. . . . . . . . . & Red-blue & 4.5 to 8.3 \\
\hline Cochineal........ & Yellow-lilac & 4.8 to 6.2 \\
\hline Alizarin red. . & Yellow-pink & 5.0 to 6.8 \\
\hline Congo red.... & Blue-red & 3.0 to 5.0 \\
\hline
\end{tabular}




\section{PREPARATION OF STANDARD SOLUTIONS}

A great many methods have been described for the standardization of solutions. Only a brief outline will be given of certain of these methods; for detailed directions the reader is referred to some of the recent textbooks on volumetric analysis.

\section{Normal Sulphuric Acid Solution}

A normal solution of sulphuric acid is one-half the molecular weight of $\mathrm{H}_{2} \mathrm{SO}_{4}$ in grams, diluted to 1 liter with distilled water. Since the molecular weight of sulphuric acid is $(2+32+64) 98$, then 49 grams, one-half of 98 , is the amount necessary for each liter.

1. In order to secure 49 grams of $\mathrm{H}_{2} \mathrm{SO}_{4}$, it requires 49 divided by 1.80 (specific gravity of concentrated sulfuric acid), or 27.2 cubic centimeters of chemically pure acid. To be sure that sufficient acid has been used, measure out about 27.5 cubic centimeters of acid.

2. Place the acid in a 1,000-cubic centimeter Erlenmeyer flask, containing about $500 \mathrm{cc}$. of water, mix well and transfer to a volumetric flask; make up to 1,000 cubic centimeters with water and mix carefully.

3. From this mixture remove 10 -cubic centimeter portions, accurately measured in a 10-cubic centimeter pipette, and place in weighing bottles which have been thoroughly cleaned, dried in an oven, cooled, and weighed.

4. One cubic centimeter of chemically pure ammonia is added to each weighing bottle to neutralize the sulphuric acid.

5. The water and excess of ammonia is then evaporated in an oven at $100^{\circ} \mathrm{C}$. and the ammonium sulphate remains behind. If the chemicals are pure, 100 cubic centimeters of the solution should give 49 grams of sulphuric acid. In 10 cubic centimeters of the solution there should be 0.49 gram of $\mathrm{H}_{2} \mathrm{SO}_{4}$.

$$
\begin{aligned}
& \mathrm{H}_{2} \mathrm{SO}_{4}:\left(\mathrm{NH}_{4}\right)_{2} \mathrm{SO}_{4}:: 98: 132 \\
& 49 \quad: \quad x \quad:: 98: 132 \\
& x \quad=0: 66
\end{aligned}
$$

If the solution is exactly normal, there should be 0.6600 gram of $\left(\mathrm{NH}_{4}\right)_{2} \mathrm{SO}_{4}$ formed from 10 cubic centimeters. In case the amount of $\left(\mathrm{NH}_{4}\right)_{2} \mathrm{SO}_{4}$ formed is too great, its factor is determined by dividing 0.6600 into the weight of ammonium sulphate found. 
If, for instance, the weight of ammonium sulphate is 0.6675 , the factor of the solution is $1.0113+$. This means that 10 cubic centimeters of the solution is equivalent to 10.113 cubic centimeters of normal solution.

\section{Normal Sodium Hydroxide Solution}

To prepare a normal solution of sodium hydroxide, weigh out roughly 45 grams of caustic soda (wash off the carbonate from the surface of the sticks of alkali) and dissolve in a little more than a liter of water. Allow this solution to stand until cool and titrate against $N / 5$ acid potassium phthalate. The preparation of $N / 5$ phthalate follows:

Molecular weight of $\mathrm{KHC}_{8} \mathrm{H}_{4} \mathrm{O}_{4}=204.14$.

Normal phthalate $=204.14$ grams in $1,000.0$ cubic centimeters of water.

Fifth normal phthalate $=40.83$ grams in $1,000.0$ cubic centimeters of water.

Weigh out 20.414 grams of dried (at 110 to $115^{\circ} \mathrm{C}$.) phthalate. Transfer to a 500-cubic centimeter flask. Dissolve in water and make up to volume.

To standardize a normal solution of $\mathrm{NaOH}$, measure 50 cubic centimeters of the $N / 5$ phthalate solution with a pipette and titrate with phenolphthalein as the indicator; 50 cubic centimeters $N / 5$ phthalate $=10$ cubic centimeters of $N / 1 \mathrm{NaOH}$.

Example. -50 cubic centimeters $N / 5$ phthalate $=9.36$ cubic centimeters of the approximately $\mathrm{N} / 1 \mathrm{NaOH}$.

$$
\frac{10}{9.36}=1.068 \text { factor for } N / 1 \mathrm{NaOH} \text {. }
$$

Make necessary dilution if an exact $N / 1$ solution is desired.

To standardize an $N / 10 \mathrm{NaOH}$ solution, dilute 20 cubic centimeters of phthalate solution to 100 cubic centimeters and titrate 25 cubic centimeter aliquots with the alkali. Calculate the factor as above or dilute if an exact $N / 10$ solution is desired.

\section{Standard $(N / 6)$ Solution of Oxalic Acid}

To prepare a standard, $N / 6$ solution of oxalic acid, dissolve 63 grams of C.P. oxalic acid $\left[(\mathrm{COOH})_{2} \cdot 2 \mathrm{H}_{2} \mathrm{O}\right]$ in 1 liter of distilled water by warming. Then dilute to exactly 6 liters with distilled water. This solution is standardized against the sodium 
hydroxide solution, using phenolphthalein as an indicator. One cubic centimeter of this solution is equivalent to exactly 1 milligram of carbon in carbon dioxide determinations.

\section{Standard $(N / 6)$ Barium Hydroxide Solution}

To prepare one liter of a $N / 6$ barium hydroxide solution, 14.28 grams of anhydrous barium hydroxide is theoretically required. However, in the process of preparation of the solution, considerable barium carbonate is formed. Hence about onefourth to one-sixth more of the hydroxide is taken than is required theoretically. Add 100 grams of C.P. anhydrous barium hydroxide to 6 liters of distilled water. Allow to dissolve for 24 hours with occasional shaking. The residue is allowed to settle for 7 days, when the supernatant solution is filtered through a double layer of filter paper. The solution is standardized to exactly $N / 6$ against the oxalic acid, using phenolphthalein as an indicator.

\section{QUALITATIVE METHODS FOR THE DETERMINATION OF VARI- OUS FORMS OF INORGANIC NITROGEN}

\section{Nessler's Reagent for Ammonia}

1. Dissolve 50 grams of potassium iodide in a small quantity of cold distilled water. (Ammonia, free; about 35 c.c.)

2. Add a saturated solution of mercuric chloride until a slight precipitate persists.

3. Now add 400 cubic centimeters of a 50 per cent solution of potassium hydroxide made by dissolving the potassium hydroxide and allowing it to clarify by sedimentation before using.

4. Dilute to 1,000 cubic centimeters, allow to settle for 1 week, and decant. This solution gives the required color with ammonia within 5 minutes after addition.

5. Keep the Nessler's solution in a well-stoppered bottle away from the light.

Test for Ammonia.-Add to a drop of Nessler's solution in a test plate a loopful of the solution to be tested. A deep goldenyellow color indicates the presence of ammonia.

The presence of glucose in solution interferes with the ammonia test. In that case, the ammonia should be removed first by aeration and then tested (see p. 63). 


\section{Thomas' Reagent for Ammonia}

Prepare a 5 per cent solution of phenol and a sodium hypochlorite solution containing 1 per cent available chlorine: 1 cubic centimeter of the $\mathrm{NaOCl}$ solution will neutralize 2.86 cubic centimeters of $0.1 \mathrm{~N}$ sodium thiosulphate.

Dilute the culture, 0.2 to 1.0 cubic centimeter with 8 cubic centimeters of water and add 1 cubic centimeter of phenol and 1 cubic centimeter of hypochlorite. Let stand for $1 / 2$ hour. A blue color indicates ammonia or amines.

\section{Trommsdorf's Reagent for Nitrites}

1. Add slowly, with constant stirring, a boiling solution of 20 grams of zinc chloride in 100 cubic centimeters of distilled water to a mixture of 4 grams of starch in water. Continue heating until the starch is dissolved as much as possible, and the solution is nearly clear.

2. Then dilute with water and add 2 grams zinc iodide.

3. Dilute to 1 liter and filter.

4. Store in well-stoppered bottles in the dark.

Test for Nitrites.-Place 3 drops of Trommsdorf's reagent in depression on test plate. Add 1 drop of dilute sulphuric acid $(1: 3)$. Remove a loopful of the solution to be tested and touch to surface of reagent. A blue color indicates the presence of nitrites.

\section{Reagents for Nitrate, Nitrite, and Hydroxylamine}

(a) Dissolve 10.5 grams sulfanilic acid and 6.8 grams sodium acetate in 1,000 cubic centimeters of 30 per cent (by volume) acetic acid, by heating on water bath. Boil for 3 minutes and make up to $1,000 \mathrm{cc}$.

(b) Boil 5 grams $\alpha$-naphthylamine in 700 cubic centimeters of water for 5 minutes, then filter and add 5 cc. of concentrated $\mathrm{HCl}$, cool and make up to $1,000 \mathrm{cc}$.

Solutions $(a)$ and $(b)$ are always kept separate.

(c) Dissolve 1.3 grams iodine in 100 cubic centimeters of glacial acetic acid.

(d) Dissolve 2.5 grams $\mathrm{Na}_{2} \mathrm{~S}_{2} \mathrm{O}_{3} \cdot 5 \mathrm{H}_{2} \mathrm{O}$ in 100 cubic centimeters of water. 
(e) Zinc dust is freed from traces of nitrates and nitrites by treating some of the pure commercial zinc dust with a dilute solution of acetic acid and heating on a water bath for 1 hour.

The zinc is filtered off by means of suction, washed with distilled water and dried.

Test for Nitrites.-Place 10 to 15 cubic centimeters of the solution to be tested into a test tube and add 1 to 2 cubic centimeter portions of solution (a) first, then an equal amount of solution $(b)$. The formation of a red color in solution indicates the presence of nitrites. This test is sensitive to $1 \times 10^{-3}$ milligram of $\mathrm{NO}_{2}^{-}$ions in 1 liter of solution. If the solution, which is to be tested for the presence of nitrite, contains free inorganic acids, it must be first neutralized with a solution of a base. The same is true of the following three methods.

Test for Nitrates, in the Absence of Nitrites.-This test is based upon the reduction of nitrates to nitrites by zinc dust.

Place 10 to 15 cubic centimeters of the solution to be tested in a test tube and add 1 to 2 cubic centimeter portions of reagents (a) and (b) as in the test for nitrites. Add also a very small pinch (about 10 to 20 milligrams) of zinc dust (e). The production of a red color indicates the presence of nitrates. Sensitivity of test, 1 milligram $\mathrm{NO}_{3}$ - ions in 1 liter of solution.

Test for Hydroxylamine in the Absence of Nitrites.-This test is based upon the oxidation of hydroxylamine $\left(\mathrm{NH}_{2} \mathrm{OH}\right)$ to nitrites by iodine.

Place 10 to 15 cubic centimeters of the solution into a test tube. Add 3 to 5 cubic centimeters of solution $(a)$ and about 5 drops of solution $(c)$. Shake and allow to stand 2 to 3 minutes in the cold. Add solution $(d)$, drop by drop, until the iodine is just decolorized. Now add 2 to 3 cubic centimeters of solution (b). The formation of a red color indicates the presence of hydroxylamine in the test solution.

Sensitivity of test, $3 \times 10^{-3}$ milligram of $\mathrm{NH}_{2} \mathrm{OH}$ in 1 liter.

Test for Nitrates and Hydroxylamine in the Presence of Nitrites. ${ }^{1-}$ The destruction of nitrites is first brought about by a diazo-reaction, which consists in adding the sulfanilic acid reagent (a) to the test solution and boiling.

${ }^{1}$ Blom, J., Ber. deut. chem. Gesell, 59 : 121, 1926. 
Place 10 to 15 cubic centimeters of the test solution in a test tube. Add 5 cubic centimeters of reagent $(a)$. Boil over free flame or heat on water bath for 4 to 5 minutes. To prove that all nitrites have been destroyed, add to 3 cubic centimeters of the mixture a few drops of reagents $(a)$ and $(b)$. The lack of formation of a red color indicates the destruction of all the nitrites.

The remaining solution containing the reagent $(a)$ is cooled down and used for the nitrate or hydroxylamine tests.

\section{Diphenylamine Reagent ${ }^{1}$}

1. Dissolve 0.7 gram of diphenylamine in a mixture of 60 cubic centimeters of concentrated sulphuric acid and 28.8 cubic centimeters of distilled water.

2. Cool this mixture and add slowly 11.3 cubic centimeters of concentrated hydrochloric acid (specific gravity 1.19). After standing overnight some of the base separates, showing that the reagent is saturated.

Test for Nitrates.-Place 1 drop of the substance to be tested in a depression on the test plate. Add 1 drop of diphenylamine solution and allow the solutions to mix thoroughly. Then add 2 drops of concentrated sulphuric acid. A deep-blue color indicates nitrates. This test cannot be made in the presence of nitrites, chloric and selenic acids, ferric chloride, and many other oxidizing agents. Diphenylbenzidine is recommended as preferable to diphenylamine. ${ }^{2}$

\section{Brucine Reagent}

Dissolve 1.0 gram of brucine in 10 cubic centimeters of 50 per cent pure sulphuric acid and make up to 100 cubic centimeters with distilled water.

Test for Nitrates.-Place 1 drop of the substance to be tested in a depression on the test plate and add 3 drops of concentrated sulphuric acid. Now add 1 drop of brucine solution. If nitrates are present, a red color develops quickly, which changes to orange,

${ }^{1}$ Withers and Ray, J. Am. Chem. Soc., 33, 708-711, 1911.

${ }^{2}$ SNell, F. D., "Colorimetric Analysis," D. Van Nostrand Co., 1921. 
then slowly to lemon or yellow, and finally becomes a greenishyellow.

This test can be used for quantitative determination of nitrates. The test is based upon the final sulphur yellow color rather than upon the initial red coloration. If the solution contains much organic matter or ferrous iron, these should be oxidized by a permanganate solution. The nitrous acid is thereby also oxidized to nitric acid and if nitrous acid is determined separately, the results should be subtracted from those of the nitric acid.

The determinations are made by adding 1 cubic centimeter of the concentrated solution of brucine and 30 cubic centimeters of concentrated sulphuric acid to 20 cubic centimeters of the solution of the unknown. In adding the sulphuric acid, care should be taken to prevent boiling.

The nitrate is determined in a colorimeter, using for comparison a standard solution containing 0.1872 gram $\mathrm{KNO}_{3}$ in 1 liter of water. This standard gives 0.0001 gram $\mathrm{N}_{2} \mathrm{O}_{5}$ or 0.00002594 gram nitrate nitrogen per 1 cubic centimeter of solution. A duplicate blank should always be made.

\section{Phenoldisulphonic Acid ${ }^{1}$}

Dissolve 25 grams of pure white phenol crystals in 150 cubic centimeters of pure concentrated sulphuric acid, add 75 cubic centimeters of fuming sulphuric acid (13 per cent $\mathrm{SO}_{3}$ ), stir well, and heat for 2 hours at about $100^{\circ} \mathrm{C}$. The reagent prepared in this way should not contain any mono-acids or any tri-acids. Two cubic centimeters of this reagent give reliable results with not more than 5 milligrams of nitrate nitrogen.

Since in strongly acid solutions the following reaction takes place, especially by heating,

$$
3 \mathrm{HNO}_{2}=\mathrm{HNO}_{3}+2 \mathrm{NO}+\mathrm{H}_{2} \mathrm{O} \text {, }
$$

a positive test for nitrate will be obtained, by the phenoldisulfonic acid and brucine methods, in solutions containing only nitrite.

${ }^{1}$ Chamot, Pratt, and Redfield, J. Am. Chem. Soc., 33, 381-384, 1911. 


\section{Test for Indol :}

Prepare test solutions:

(a) Paradimethylaminobenzaldehyde........ $1.0 \mathrm{gm}$.

Absolute alcohol.................. 95.0 cc.

Hydrochloric acid (specific gravity 1.2).... $20.0 \mathrm{cc}$.

(b) Potassium persulphate............ $1.0 \mathrm{gm}$.

Distilled water.................. $100.0 \mathrm{cc}$.

Place a few drops of solutions $(a)$ and $(b)$ on a piece of absorbent cotton. Push the cotton into the test tube until the moistened surface is within about 1 inch of the culture liquid. Now place the tube in boiling water for 5 to 10 minutes. If indol is present, a red color will appear on the bottom of the cotton plug.

\section{DETERMINATION OF MOISTURE IN SOIL}

Weigh from 5 to 10 grams of soil into a glass or aluminum dish and dry at 100 to $105^{\circ} \mathrm{C}$. until there is no further change in weight. About 6 to 12 hours are generally sufficient. Cool in a desiccator and weigh. Determine all percentages of moisture on the dry basis.

\section{MOISTURE-HOLDING CAPACITY OF SOIL}

To determine the amount of moisture which is required to saturate the particular soil, the following procedure is used: Round copper cups, about 4 to 5 centimeters in diameter and about 2 centimeters high, with a perforated copper bottom are used. Pieces of filter paper are cut to fit exactly upon the bottom of the cups; the paper is moistened and the cups with the moistened paper weighed. The cups are then filled with the soil in question and the surface is leveled off carefully with the edge of the cup. The cups are then weighed again. The cups with soil are now placed in a dish with water, the water reaching outside of the cup to about half its height. After 24 hours the soil has become saturated with water; the cups are removed and the surface carefully dried with a cloth to remove water adhering to outside of cup, and weighed again. The cups are then placed in a drying oven for 24 hours, at $105^{\circ} \mathrm{C}$., until they come to constant weight. The soil is now carefully and completely removed from the cup and from paper, and these weighed again, giving weight of cup and dry paper. The moisture-holding 
capacity of the soil as well as the moisture content of the particular soil can be calculated from these data.

\section{QUANTITATIVE METHODS FOR AMMONIA DETERMINATION}

\section{Direct Distillation :}

Sulphuric acid solution................ $/ 14$

Sodium hydroxide solution. .............

Methyl-red.

Magnesium oxide.

1. Transfer the culture to be analyzed to an 800-cubic centimeter Kjeldahl or a copper flask, using about 200 cubic centimeters of distilled water.

2. Add 5 grams of magnesium oxide and some shavings of paraffin to prevent foaming.

3. Connect to a condenser, the lower end of which is in $N / 14$ acid contained in an Erlenmeyer flask.

The period of distillation will vary with the amount of ammonia present. As a rule, 1 hour is long enough to drive off all ammonia nitrogen.

4. If methyl-red is used as an indicator, the distillate should be boiled for a few minutes, cooled to 15 or $20^{\circ} \mathrm{C}$., about 5 drops of methyl-red added, and the solution titrated.

5. The distillate is titrated with standard alkali, and from the number of cubic centimeters of standard acid neutralized by the distillate the weight of nitrogen liberated as ammonia is calculated.

2. Nesslerization.-Ammonia-free water should be prepared by adding sodium hydroxide and potassium permanganate to laboratory water and redistilling. Discard the first portion of the distillate. After about one-fourth of the water has been evaporated, the subsequent distillate will be free of ammonia.

Standard Ammonium Chloride Solution.-Dissolve 3.82 grams of ammonium chloride in 1,000 cubic centimeters of distilled water; dilute 10 cubic centimeters of this to 1,000 cubic centimeters with ammonia-free water. One cubic centimeter of this solution contains 0.01 milligram of nitrogen.

1. Prepare a series of 16 Nessler's tubes which contain the following number of cubic centimeters of the standard ammonium chloride solution, and dilute to 50 cubic centimeters with 
ammonia-free water, namely: $0.0,0.1,0.3,0.5,0.7,1.0,1.4,1.7$, $2.0,2.5,3.0,3.5,4.0,4.5,5.0$, and 6.0 .

2. These will contain 0.01 milligram of ammonia nitrogen for each cubic centimeter of the standard solution used.

3. Nesslerize the standards and also the distillates by adding approximately 2 cubic centimeters of Nessler's reagent to each tube.

4. Do not stir the contents of the tubes.

5. After Nesslerizing, allow the tubes to stand for 10 minutes.

6. Compare the color produced in these tubes with that in the standards by looking vertically downward through them at a white surface placed at an angle in front of a window, so as to reflect the light upward.

3. Aeration Method. ${ }^{-}$-Place in a Kjeldahl flask 100 grams of soil to be analyzed, 4 grams of sodium carbonate, 0.5 cubic centimeter paraffin oil, and about 300 cubic centimeters of ammonia-free water. Apply suction, bubbling the air first through weak (10 per cent) sulphuric acid solution, to remove any ammonia that might be present in the air; the air is bubbled through the solution containing the soil and then is bubbled through a bottle or long tube containing standard sulphuric acid $0.2 N, 0.1 N$, or $0.05 N$ depending on the amount of ammonia present), where the ammonia is absorbed. The flasks containing the soil are placed in a water bath, the temperature of which is maintained at 75 to $80^{\circ} \mathrm{C}$. Aeration is continued for 2 to 3 hours. In the case of liquid cultures, 30 to 50 cubic centimeter portions of the culture solution are placed in Folin æration tubes, 5 cubic centimeters of 20 per cent sodium carbonate solution, 1 gram $\mathrm{NaCl}$ and 0.5 cubic centimeter petroleum oil are added to each and aeration continued for 3 hours, tubes being placed in thermostat at 60 to $65^{\circ} \mathrm{C}$.

\section{QUANTITATIVE (COLORIMETRIC) METHOD FOR DETERMINING NITRATES}

Evaporate to dryness in a porcelain dish on a water bath a convenient quantity of unknown nitrate solution, depending upon the amount of nitrate present.

${ }^{1}$ Gibis, W. M., et al., Soil Sci., 15 : 261-267, 1923. 
This solution should be alkaline. In the case of soil extracts which had been treated with $\mathrm{CaO}$ in filtration no further treatment is necessary. In other cases, the solution should be treated with $\mathrm{NaOH}$ or limewater to render slightly alkaline before evaporation.

When evaporated, add 2 cubic centimeters of phenoldisulphonic acid and stir with the rounded end of a glass rod for about 10 minutes so as to loosen the residue.

NoтE.-Equations for the action of phenoldisulphonic acid on a nitrate:

$$
\begin{gathered}
\mathrm{H}_{2} \mathrm{SO}_{4}+2 \mathrm{KNO}_{3}=2 \mathrm{HNO}_{3}+\mathrm{K}_{2} \mathrm{SO}_{4} . \\
\mathrm{C}_{6} \mathrm{H}_{3}(\mathrm{OH})\left(\mathrm{SO}_{3} \mathrm{H}\right)_{2}+\mathrm{HNO}_{3}=\mathrm{C}_{6} \mathrm{H}_{2}(\mathrm{OH})\left(\mathrm{SO}_{3} \mathrm{H}\right)_{2}\left(\mathrm{NO}_{2}\right)+\mathrm{H}_{2} \mathrm{O} . \\
\mathrm{C}_{6} \mathrm{H}_{2}(\mathrm{OH})\left(\mathrm{SO}_{3} \mathrm{H}\right)_{2}\left(\mathrm{NO}_{2}\right)+3 \mathrm{NH}_{4} \mathrm{OH}= \\
\mathrm{C}_{6} \mathrm{H}_{2}\left(\mathrm{ONH}_{4}\right)\left(\mathrm{SO}_{2} \mathrm{ONH}_{4}\right)_{2} \mathrm{NO}_{2}+3 \mathrm{H}_{2} \mathrm{O} .
\end{gathered}
$$

Dilute with water and add ammonia solution (strong ammonium hydroxide diluted with an equal volume of water) until alkaline; a yellow color is formed. This is then diluted to a known volume and compared with the standard.

Example.-Take 500 cubic centimeters of water to 100 grams of soil, and in order to clarify add about 2 grams of calcium oxide. To secure a fair sample, mix by rubbing in a mortar or by shaking in a wide-mouthed bottle. Filter through folded filter paper until clear. Take a convenient volume, for example, 25 cubic centimeters, and determine the nitrate present. This is equal to 5 grams of soil. Use the colorimeter to compare the standard solution with the unknown.

Formula for calculating results:

$$
X=\frac{100}{W} \cdot \frac{S}{A} \cdot d \cdot \frac{K}{U} \cdot M
$$

Where $X=$ Number of milligrams of $\mathrm{N}$ as $\mathrm{NO}_{3}$ per 100 grams dry soil.

$W=$ Weight of dry soil.

$S=$ Cubic centimeters of water added to $W$.

$A=$ Aliquot taken for evaporation.

$d=$ Number of cubic centimeters to which $A$ was diluted.

$K=$ Reading on scale of standard solution.

$U=$ Reading on scale of unknown solution.

$M=$ Milligrams of $\mathrm{N}$ as $\mathrm{NO}_{3}$ in 1 cubic centimeter of standard solution as diluted for reading.

Standard Nitrate Solution.-Dissolve 0.722 gram of pure dry potassium nitrate in 1,000 cubic.centimeters of water. Of this strong solution dilute 10 to 100 cubic centimeters, and from this 
take 10 cubic centimeters for a standard. Evaporate to dryness in a porcelain dish on a water bath and treat as described on $p$. 64. Make up volume to 100 cubic centimeters. This standard is equal to 0.1 milligram of nitrogen as nitrate.

Determination of Nitrates by the Reduction Method

Prepare an aqueous extract of the soil, peat or decomposing organic matter which is to be analyzed. Extract 50 or 100 grams of the material three to six times with water and filter through a folded paper, so as to collect 250 cubic centimeters of solution. This solution is collected into a 500-cubic centimeter Kjeldahl flask.

Add 5 cubic centimeters of a 50 per cent solution of sodium hydroxide and distill over an open flame, until about 100 to 150 cubic centimeters have been driven over.

Replace the water driven off in heating.

When cool, add 2 grams of finely divided Devarda's alloy (about 60-mesh) and connect flask again with distilling apparatus.

Boil carefully for 30 to 60 minutes and collect the distillate in a definite volume of standard acid solution.

Titrate the solution with standard alkali and calculate the nitrate-nitrogen distilled over as ammonia.

By this method one can determine both ammonia and nitrate in soil, in peat, in manure, or in other organic composts. For this purpose the original extract is made with 4 per cent $\mathrm{KCl}$ solution instead of water. The first distillate will give the ammonia present (collected in standard acid solution) and the second distillate the nitrate.

\section{QUANTITATIVE METHODS FOR DETERMINATION OF TOTAL NITROGEN}

Sulphuric acid.......................... N/14

Sodium hydroxide........................ N/14

Sulphuric acid (concentrated)

Potassium or sodium sulphate

Mercuric oxide or metallic mercury

Copper sulphate

Pumice powder or zinc powder free of nitrogen

Sodium hydroxide (40 per cent)

Place a 10-gram sample of soil in a dry Kjeldahl flask of 800cubic centimeters capacity. 
Add 0.7 gram of mercuric oxide, 0.1 to 0.3 grams of crystalline copper sulphate, and 10 grams of anhydrous sodium sulphate or powdered potassium sulphate.

Add 30 to 35 cubic centimeters of concentrated sulphuric acid. Thoroughly moisten the whole sample with acid before beginning to heat.

Place the flask on the digestion shelf and heat slowly until frothing ceases. Avoid a very high flame; do not allow the flame to touch the flask above the part occupied by the liquid.

Now raise the heat (avoid a very hot flame) until the acid boils rapidly.

Digest for some hours after the liquid clears-until the cool liquid is no longer yellow but blue-white in color.

In case the contents of the flask are likely to become solid before digestion is complete, cool, and add 10 cubic centimeters more of sulphuric acid.

When digestion is complete, cool, and add about 300 cubic centimeters of water. Shake until the mixture is thoroughly in solution. Be sure that none of the digested material remains caked to the sides of the Kjeldahl flask.

Recool, add a teaspoonful of powdered pumice or a small amount of zinc powder ( 0.5 gram) to prevent bumping.

Add 25 cubic centimeters of an 8 per cent sodium thiosulphate solution in order to precipitate the mercury.

Add 80 to 100 cubic centimeters of the concentrated sodium hydroxide. (The stock solution of alkali should be prepared 2 days or more before it is to be used in order that the sodium carbonate may precipitate out. Avoid the deposit in the bottom of the alkali.) Enough alkali should be added to the acid digest to make the solution react strongly alkaline. A few strips of litmus paper may be added in order to test the reaction. The alkali should be poured slowly down the sides of the flask, connected at once to the condenser, and shaken.

See that the rubber stopper fits snugly in the flask. Now mix the contents thoroughly by shaking.

Just before connecting the flask have a very low flame burning on the distillation shelf. After the alkali and acid mixture are well mixed, raise the flame. 
The proper amount of standard acid should be measured into flasks connected to the distillation shelf prior to adding the alkali.

Distill slowly. After the first 15 minutes the flame may be raised, but never so high that the distillate collects in the condensing bulbs. Generally the first two-thirds of the original volume recovered as distillate will contain all the ammonia.

The distillate is now titrated with standard alkali, using methyl-red or any other convenient indicator. From the cubic centimeters of standard acid neutralized by the distillate the weight of nitrogen liberated as ammonia is calculated.

Methyl-red Indicator.-Dissolve 1 gram of methyl red in 50 cubic centimeters of 95 per cent alcohol and dilute to 100 cubic centimeters with water. Filter if the solution is turbid.

The percentage of nitrogen should be reported on the dry basis of the soil.

A. Quantitative Methods for Determination of Total Nitrogen Including Nitrates

Follow the same method as described under Quantitative Methods for Total Nitrogen Determination, except for the use of salicylic acid and sodium thiosulphate during digestion.

Add to the substance to be analyzed in a Kjeldahl flask, 10 cubic centimeters of sulphuric acid with salicylic acid (1 gram in 30 cubic centimeters of sulphuric acid); shake until thoroughly mixed and allow to stand 5 or 10 minutes, with frequent shaking.

Now add 10 grams of sodium thiosulphate and heat the solution gently for 5 minutes, then bring to boiling for 5 minutes; cool; add 0.5 gram of copper sulphate and mercuric oxide and boil. This reduces the danger of foaming. Heat gently until $\mathrm{SO}_{3}$ fumes begin to come off. Cool. Add 15 cubic centimeters of the salicylic - sulphuric acid reagent, making in all 25 cubic centimeters of acid in each flask.

Heat very gently until foaming ceases, then heat strongly until colorless. Continue boiling for 2 hours after substance is colorless. The entire process requires 5 to 6 hours.

Follow the directions as given in Quantitative Methods for Total Nitrogen Determination. 


\section{B. Total Nitrogen Including Nitrates in Aqueous Solu- tions (Davisson-Parsons Method) ${ }^{1}$}

In addition to the usual apparatus for Kjeldahl analysis, prepare absorbing towers as shown in Fig. 2. Place 35 cubic centimeters of sulphuric acid in each glass bead tower (concentrated $\mathrm{H}_{2} \mathrm{SO}_{4} 4$ parts and water 1 part).

Take 100 cubic centimeters of the liquid to be analyzed, e.g.,

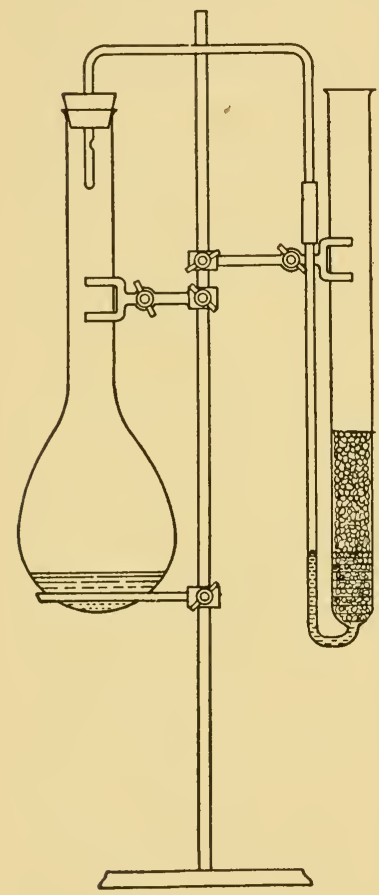

Frg. 2.-Apparatus for measuring total nitrogen in the presence of nitrates. soil extract (if rich in nitrogen a suitable aliquot may be used). Place the 100 cubic centimeters in an 800-cubic centimeter Kjeldahl flask and add sufficient strong sodium hydroxide to make the solution approximately $0.1 \mathrm{~N} \mathrm{NaOH}$. Now add 4 drops of paraffin oil and one gram of Devarda's alloy (60-mesh, made free of ammonia by heating to about $200^{\circ} \mathrm{C}$. for 30 minutes) and immediately connect to the glass bead tower. Heat with a rose top burner (high flame) until boiling, boil gently for 20 minutes (during this time the acid in the tower should about reach the boiling temperature). Remove the flame, allow the acid to suck back into the flask, and again bring the solution in Kjeldahl flask to the boiling temperature. Boil for a few minutes. Wash the tower with small quantities of distilled water and allow the water to suck back into the flask. About four washings of 25 cubic centimeters each will be found sufficient to remove all of the ammonia from the tower. Place on Kjeldahl digestion shelf and heat with a low flame until the organic matter begins to char. Now add 5 grams of potassium sulphate and continue digestion

${ }_{1}^{1}$ Davisson, B. S. and J. T. Parsons, J. Ind. Eng. Chem., 11: 306-311, 1919. JACOB, K. D. and W. J. Geldard, J. Ind. Eng. Chem., 14: 10451047, 1922. 
for about 2 hours after the liquid becomes clear. When completed, cool, add water, pumice stone, and strong alkali carrying potassium or sodium sulfide ( 0.4 per cent) and distill as in the official Kjeldahl method.

\section{DETERMINATION OF AMINO NITROGEN}

Amino acids and other amino compounds can be determined gravimetrically or colorimetrically, either by the Van Slyke method, ${ }^{1}$ which is based upon the interaction of nitrous acid with the amino group, giving gaseous nitrogen; by the Sörensen formalin titration method, ${ }^{2}$ and by the Folin colorimetric method. ${ }^{3}$

\section{QUANTITATIVE DETERMINATION OF CARBOHYDRATES}

1. Free Celluloses.-True celluloses are characterized by the fact that they are insoluble in dilute acids ( 2 to 4 per cent), but they are soluble in concentrated acids, such as 42 per cent hydrochloric or 72 per cent sulphuric. The quantitative determination of pure cellulose in soil or in culture is based upon its solubility in ammoniacal copper solution, from which it is reprecipitated by alcohol.

Preparation of Schweitzer's Reagent.-Two hundred grams of copper sulphate are dissolved in hot water and precipitated with a calculated amount of ammonia (95 cubic centimeters of ammonia, specific gravity 0.90 ). The excess of ammonia is then neutralized with sulphuric acid. The precipitate is washed by decantation in a large bottle three or four times and is then transferred to a Büchner funnel and filtered through hardened filter paper by the use of suction. With the aid of a porcelain spoon the excess of water is pressed out from the copper hydroxide. It is then removed in the form of a hardened paste from the filter paper and introduced into a bottle containing ammonia water and shaken in a shaking machine for 4 to 5 hours. An undissolved part of the copper hydroxide should remain at the bottom of the flask. The Schweitzer's reagent prepared in this way should contain 1.5 grams of copper per 100 cubic centimeters of solution.

${ }^{1}$ Van Slyke, D. D., J. Biol. Chem., 10 : 15-55, 1911, 12 : 275-284, 1912; 16 : 539-547, 1913.

2 Sörensen, S. P. L., Biochem. Z., 7 : 45, 1907-1908.

${ }^{3}$ Folin, O., J. Biol. Chem., 51: 377, 1922. 
To test the strength of the reagent, 5 cubic centimeters are placed in a crucible of constant weight, near a dish of $\mathrm{H}_{2} \mathrm{SO}_{4}$ under a bell jar. As soon as all the ammonia is absorbed, the $\mathrm{Cu}(\mathrm{OH})_{2}$ is dried and heated to constant weight and weighed as $\mathrm{CuO}$.

Cellulose Determination. ${ }^{1-}$ Cellulose is added to the soil either in the form of finely cut or well ground filter paper. After the soil is properly mixed, a 20-gram sample is obtained from moist, or preferably air-dried, soil. The sample is placed in a 250-cubic centimeter sampling bottle, 100 cubic centimeters of Schweitzer's reagent is added; the bottle is then stoppered with a rubber stopper and shaken for an hour in a shaking machine. After settling, somewhat more than 50 cubic centimeters of the liquid is filtered through a Gooch crucible by the use of suction. Fifty cubic centimeters of the filtrate are then precipitated with 200 cubic centimeters of 80 per cent alcohol and the precipitate is filtered through a Gooch crucible and washed as follows: (1) dilute 1 per cent $\mathrm{HCl}$, (2) warm distilled water, (3) dilute 2 per cent $\mathrm{KOH}$ to get rid of humic acids-washing with $\mathrm{KOH}$ is continued until all brown color disappears, (4) warm distilled water, (5) dilute 1 per cent $\mathrm{HCl}$ to get rid of free alkali, (6) warm distilled water until free from chlorides, (7) alcohol-after cooling the crucible, (8) ether.

Dry to constant weight at $110^{\circ} \mathrm{C}$., weigh, burn off and weigh again. The difference between the two weights gives the quantity of cellulose for 10 grams of the sample.

2. Celluloses in Plant Tissues. - Treat fresh or decomposed material with 2 per cent solution of hydrochloric acid for 5 hours under reflux condenser. Filter, and wash residue. Take aliquot portion of residue and treat with 10 volumes of 80 per cent solution of $\mathrm{H}_{2} \mathrm{SO}_{4}$, then proceed as outlined on page 77 . Calculate cellulose content in original material.

3. Pentosans. - The determination of pentosans is based upon their transformation into furfural when boiled with 12 per cent hydrochloric acid: 2 grams of material are placed in a 500-cubic centimeter flask provided with a separatory funnel and an

${ }^{1}$ Charpentier, C. A. G. Thesis, Helsingfors, 1921; Waksman, S. A., and O. Heukelekian, Soil Sci., 17: 275-292, 1924; Barthel, Chr., Abderhalden's Handbuch, p. 754, 1927. 
outlet tube connected with condenser. One hundred cubic centimeters of 12 per cent hydrochloric acid (specific gravity 1.06) is added from separatory funnel, and 30 cubic centimeters distilled over in 10 minutes, the distillate passing through small filter paper into receiver. As soon as 30 cubic centimeters of the distillate are collected, 30 cubic centimeters more $\mathrm{HCl}$ is added to flask and distillation continued. This is repeated until 270 cubic centimeters of distillate are collected. Forty cubic centimeters of filtered phloroglucide solution (11 grams of phloroglucinol dissolved in 300 cubic centimeters of 12 per cent hydrochloric acid) are added to the distillate and made up to 400 cubic centimeters with hydrochloric acid. After standing 16 hours, the precipitate is filtered off using a weighed Gooch crucible with thick asbestos mat. Wash with 150 cubic centimeters of water, dry at 100 to $105^{\circ} \mathrm{C}$. for 4 hours, and weigh. If $a$ is the weight of the precipitate, the pentosan content is, when less than 0.03 gram

$$
(a-0.0052) \times 0.8949 .
$$

When the precipitate weighs 0.03 to 0.3 gram, the pentosan content is

$$
(a-0.0052) \times 0.8866 .
$$

4. Starches.-Starches are soluble in hot water and are readily hydrolized by dilute acids and by diastatic enzymes giving the reducing sugars maltose and glucose.

A definite amount of material (4 to 5 grams), previously extracted with ether and alcohol, is treated with 50 cubic centimeters of water, in a double boiler and brought to the boiling point; it is kept at that point for 15 minutes, until all the starch has gelatinized. The mixture is then cooled to $50^{\circ} \mathrm{C}$. and treated with 10 cubic centimeters of malt extract. The temperature $\left(50^{\circ} \mathrm{C}\right.$.) is maintained for 30 to 60 minutes. The mixture is again heated, cooled to $50^{\circ} \mathrm{C}$., again treated with 10 cubic centimeters of the malt extract, and incubated for 30 to 60 minutes, until no blue color is given with iodine solution. The mixture is made up to 250 cubic centimeters and filtered through paper; 200 cubic centimeters of the filtrate is treated with 20 cubic centimeters of hydrochloric acid solution (specific gravity 1.125) and heated, under a reflux condenser, for 2 hours. 
The solution is cooled, neutralized with sodium hydroxide solution, and made up to 500 cubic centimeters. The solution is filtered and reducing sugar (glucose) determined in an aliquot portion. A blank determination of 20 cubic centimeters malt extract boiled with acid as before outlined is subtracted. The amount of glucose calculated is multiplied by 0.9 to give the weight of starch.

5. Reducing Sugars.--Reducing sugars may be determined conveniently by the Bertrand or the modified Shaffer and Hartmann ${ }^{1}$ method or by any other convenient method.

Micro Method.-Prepare the following reagents:

(a) Combined micro reagent:

Grams per Liter

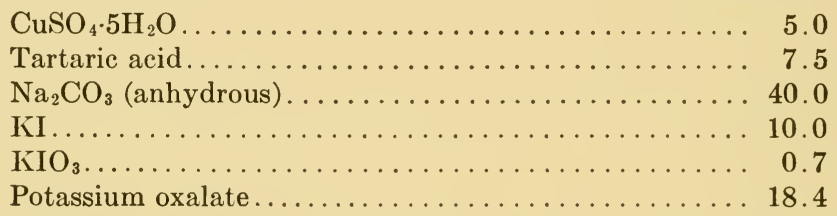

The sodium carbonate is dissolved in about 400 cubic centimeters of warm water, and into this, with stirring, is poured the copper sulphate and tartaric acid dissolved in about 150 cubic centimeters of water. The iodate, iodide, and oxalate are dissolved in about 250 cubic centimeters of water, rinsed into the alkaline copper solution, cooled and diluted to a liter. It is usually more convenient to make up a larger quantity based on the same proportion of reagents.

(b) $1 N \mathrm{H}_{2} \mathrm{SO}_{4}-27$ cubic centimeters of concentrated $\mathrm{H}_{2} \mathrm{SO}_{4}$ are poured into a quantity of water and diluted to a liter. The resulting solution is approximately normal but can be readily adjusted by titration.

(c) $0.1 \mathrm{~N}$ thiosulphate -25 grams of pure sodium thiosulphate and 1 gram of $\mathrm{NaOH}$ are dissolved in water and diluted to a liter. This should give a solution a trifle stronger than $0.1 N$. It can be readily standardized with a solution of $0.1 N \quad \mathrm{~K}_{2} \mathrm{Cr}_{2} \mathrm{O}_{7}$. To prepare this solution pure $\mathrm{K}_{2} \mathrm{Cr}_{2} \mathrm{O}_{i}$ is dried at $110^{\circ} \mathrm{C}$., and 4.9033 grams are dissolved in water and diluted to 1 liter. Twenty-five cubic centimeters of the standard dichromate are

${ }^{1}$ Stiles, H. R., W. H. Peterson, and E. B. Fred, J. Bact., 12 : 427-439, 1926. 
transferred to a large beaker containing about 3 grams KI and 10 cubic centimeters strong $\mathrm{HCl}$ in aqueous solution. The contents are diluted to 500 or 600 cubic centimeters and titrated with the thiosulphate. Starch paste is added toward the end of the reaction, and at the end point the solution turns from a blue to a light green. If the thiosulphate used is pure, the volume will be a little less than 25 cubic centimeters, and the solution can be readily adjusted to $0.1 N$ by dilution with water. Thus if the titration is 24.7 cubic centimeters thiosulphate, every 24.7 cubic centimeters of thiosulphate solution should have added to it 0.3 cubic centimeters water, or to 914 cubic centimeters of the remaining solution add $\frac{914}{24.7} \times 0.3$ or 11.1 cubic centimeters of water. The resulting solution should be $0.1 N$ and can be readily checked against the $0.1 N$ dichromate. The $0.1 N$ thiosulphate solution thus prepared will keep its strength for more than a year. To make $0.005 N$ thiosulphate, 25 cubic centimeters of the $0.1 N$ solution are diluted to 500 cubic centimeters in a volumetric flask and mixed. This solution keeps for only a few days and is best prepared anew for each set of determinations.

(d) Basic lead acetate, Horne reagent-A 33 per cent solution is used.

(e) Phosphate solution-For removing excess lead, a 10 per cent solution of $\mathrm{Na}_{2} \mathrm{HPO}_{4} \cdot 12 \mathrm{H}_{2} \mathrm{O}$ is used. Three cubic centimeters are required for every cubic centimeter of the lead acetate solution used. Add phenolphthalein and if alkaline or acid neutralize.

Place 10 or 25 cubic centimeters of culture, depending on the percentage of sugar, in a 50-cubic centimeter volumetric flask, add a few drops of phenolphthalein and neutralize with sodium hydroxide. Add 1 cubic centimeter of lead acetate solution, shake, and then add 3 cubic centimeters of phosphate solution. If alkaline or acid, neutralize, dilute to exactly 50 cubic centimeters and mix thoroughly by inverting. Let stand for 3 minutes and then remove an aliquot for analysis by means of a pipette. If chlorides or other compounds precipitable by lead are present, a little more of the lead acetate solution can be used. An excess of lead acetate is to be avoided for some of the sugar will be carried down with the precipitate. 
Micro Sugar Table-Glucose Corresponding to Difference in Titration between Control and Sample

\begin{tabular}{|c|c|c|c|c|c|c|c|}
\hline $\begin{array}{c}0.005 \mathrm{~N} \\
\text { Thiosul- } \\
\text { phate, } \\
\text { Cubic } \\
\text { Centimeters }\end{array}$ & $\begin{array}{l}\text { Glucose, } \\
\text { Milli- } \\
\text { gram }\end{array}$ & $\begin{array}{c}0.005 N \\
\text { Thiosul- } \\
\text { phate, } \\
\text { Cubic } \\
\text { Centi- } \\
\text { meters }\end{array}$ & $\begin{array}{c}\text { Glucose, } \\
\text { Milli- } \\
\text { grams }\end{array}$ & $\begin{array}{c}0.005 N \\
\text { Thiosul- } \\
\text { phate, } \\
\text { Cubic } \\
\text { Centi- } \\
\text { meters }\end{array}$ & $\begin{array}{c}\text { Glucose, } \\
\text { Milli- } \\
\text { grams }\end{array}$ & $\begin{array}{c}0.005 N \\
\text { Thiosul- } \\
\text { phate, } \\
\text { Cubic } \\
\text { Centi- } \\
\text { meters }\end{array}$ & $\begin{array}{c}\text { Glucose, } \\
\text { Milli- } \\
\text { grams }\end{array}$ \\
\hline 0.3 & 0.067 & 4.1 & 0.622 & 8.1 & 1.159 & 12.1 & 1.649 \\
\hline 0.4 & 0.086 & 4.2 & 0.634 & 8.2 & 1.173 & 12.2 & 1.662 \\
\hline 0.5 & 0.105 & 4.3 & 0.647 & 8.3 & 1.186 & 12.3 & 1.674 \\
\hline 0.6 & 0.125 & 4.4 & 0.660 & 8.4 & 1. 198 & 12.4 & 1.687 \\
\hline 0.7 & 0.142 & 4.5 & 0.672 & 8.5 & 1.211 & 12.5 & 1.700 \\
\hline 0.8 & 0.157 & 4.6 & 0.685 & 8.6 & 1.224 & 12.6 & 1.713 \\
\hline 0.9 & 0.173 & 4.7 & 0.698 & 8.7 & 1.237 & 12.7 & 1.728 \\
\hline \multirow[t]{2}{*}{1.0} & 0.191 & 4.8 & 0.713 & 8.8 & 1.249 & 12.8 & 1.742 \\
\hline & & 4.9 & 0.729 & 8.9 & 1.262 & 12.9 & 1.756 \\
\hline 1.1 & 0.210 & 5.0 & 0.745 & 9.0 & 1.275 & 13.0 & 1.770 \\
\hline 1.2 & 0.229 & & & & & & \\
\hline 1.3 & 0.247 & 5.1 & 0.759 & 9.1 & 1.288 & 13.1 & 1.785 \\
\hline 1.4 & 0.263 & 5.2 & 0.772 & 9.2 & 1.300 & 13.2 & 1.800 \\
\hline 1.5 & 0.279 & 5.3 & 0.784 & 9.3 & 1.313 & 13.3 & 1.813 \\
\hline 1.6 & 0.294 & 5.4 & 0.797 & 9.4 & 1. 326 & 13.4 & 1.827 \\
\hline 1.7 & 0.306 & 5.5 & 0.810 & 9.5 & 1. 339 & 13.5 & 1.842 \\
\hline 1.8 & 0.319 & 5.6 & 0.822 & 9.6 & 1.354 & 13.6 & 1.856 \\
\hline 1.9 & 0.332 & 5.7 & 0.837 & 9.7 & 1. 368 & 13.7 & 1.871 \\
\hline \multirow[t]{2}{*}{2.0} & 0.344 & 5.8 & 0.852 & 9.8 & 1. 382 & 13.8 & 1.885 \\
\hline & & 5.9 & 0.868 & 9.9 & 1.397 & 13.9 & 1.899 \\
\hline 2.1 & 0.357 & 6.0 & 0.882 & 10.0 & 1.411 & 14.0 & 1.913 \\
\hline 2.2 & 0.370 & & & & & & \\
\hline 2.3 & 0.382 & 6.1 & 0.892 & 10.1 & 1.424 & 14.1 & 1.928 \\
\hline 2.4 & 0.395 & 6.2 & 0.902 & 10.2 & 1.435 & 14.2 & 1.942 \\
\hline 2.5 & 0.408 & 6.3 & 0.911 & 10.3 & 1.446 & 14.3 & 1.956 \\
\hline 2.6 & 0.421 & 6.4 & 0.926 & 10.4 & 1.457 & 14.4 & 1.971 \\
\hline 2.7 & 0.434 & 6.5 & 0.940 & 10.5 & 1.469 & 14.5 & 1.984 \\
\hline 2.8 & 0.446 & 6.6 & 0.955 & 10.6 & 1.480 & 14.6 & 1.997 \\
\hline 2.9 & 0.461 & 6.7 & 0.969 & 10.7 & 1.491 & 14.7 & 2.010 \\
\hline \multirow[t]{2}{*}{3.0} & 0.477 & 6.8 & 0.983 & 10.8 & 1.502 & 14.8 & 2.022 \\
\hline & & 6.9 & 0.997 & 10.9 & 1.513 & 14.9 & 2.035 \\
\hline 3.1 & 0.493 & 7.0 & 1.010 & 11.0 & 1.524 & 15.0 & 2.048 \\
\hline 3.2 & 0.507 & & & & & & \\
\hline 3.3 & 0.520 & 7.1 & 1.023 & 11.1 & 1.535 & & \\
\hline 3.4 & 0.532 & 7.2 & 1.036 & 11.2 & 1.547 & & \\
\hline 3.5 & 0.545 & 7.3 & 1.048 & 11.3 & 1.558 & & \\
\hline 3.6 & 0.558 & 7.4 & 1.061 & 11.4 & 1.569 & & \\
\hline 3.7 & 0.571 & 7.5 & 1.074 & 11.5 & 1.580 & & \\
\hline 3.8 & 0.583 & 7.6 & 1.088 & 11.6 & 1.591 & & \\
\hline 3.9 & 0.596 & 7.7 & 1.102 & 11.7 & 1.602 & & \\
\hline \multirow[t]{3}{*}{4.0} & 0.609 & 7.8 & 1.116 & 11.8 & 1.613 & & \\
\hline & & 7.9 & 1. 130 & 11.9 & 1.624 & & \\
\hline & & 8.0 & 1.145 & 12.0 & 1.636 & & \\
\hline
\end{tabular}


Place 5 cubic centimeters of the micro reagent in a 50-cubic centimeter Pyrex test tube and to this add from 1 to 5 cubic centimeters, depending upon the quantity of sugar present, of the clarified sample. If less than 5 cubic centimeters of sample is taken, add sufficient water to make the total volume 10 cubic centimeters. At the same time make up a blank with 5 cubic centimeters of water and 5 cubic centimeters of reagent. Stopper the test tubes with loose-fitting corks, to prevent oxidation from the air, and heat for 15 minutes in a boiling water bath. Cool in running water, add 5 cubic centimeters of $1 \mathrm{~N} \mathrm{H}_{2} \mathrm{SO}_{4}$, shake well, let stand 1 minute and titrate with $0.005 N$ thiosulphate and starch paste as an indicator. Add the starch solution when the solution has turned a light straw color which indicates that only a trace of iodine remains. Continue the titration with thiosulphate until the blue color of the starch iodine compound completely disappears. The end point is very sharp-within 1 to 2 drops of thiosulphate.

Calculation may be made directly from the micro-sugar table. The titration of the sample in cubic centimeters of $0.005 \mathrm{~N}$ thiosulphate is subtracted from the titration of the blank, the difference found in the table and read in milligrams of glucose. The glucose per cubic centimeter of sample is then calculated from the glucose found in the aliquot taken.

When 1 cubic centimeter of culture is taken for the direct determination, this method will accommodate samples containing up to 0.20 per cent glucose. If the sugar percentage is greater, the sample must be diluted. For a sugar concentration of about 0.50 per cent, a convenient dilution would be 10 cubic centimeters made up to 50 cubic centimeters and a 1 cubic centimeter aliquot taken.

6. Lignins.-Lignins are prepared and determined by treating natural or decomposed organic materials with 42 per cent hydrochloric acid, ${ }^{1} 72$ per cent sulphuric acid or a mixture of hydrochloric and sulphuric acids; the acids decompose all the celluloses, pentosans and proteins, leaving the lignins unattacked. Four 2-gram portions of organic material, such as straw, ground wood shavings, etc., are treated with ether to remove the fats

${ }^{1}$ Willstätter, R., and L. Zeichmeister, Ber. deut. Chem. Gesell., 46 : 2401, 1913. Schwallee, H., Papierfabr., 23 : 174-177, 1925. 
and waxes. After the ether has been removed, the residue is placed in a glass-stoppered flask or bottle and covered with 10 cubic centimeters of 18 per cent hydrochloric acid solution and 50 cubic centimeters of 72 per cent sulphuric acid solution. The flask is stoppered, shaken, and immediately immersed in cold water. The reacting mixture is allowed to stand for 2 to 3 hours, then transferred with 300 cubic centimeters of water to 500 -cubic centimeter flasks and boiled for 30 minutes. The residue is filtered off upon dried and weighed paper or Gooch crucible, and washed with an excess of water. The residues are then dried at $70^{\circ} \mathrm{C}$. to constant weight. Two portions are used for ashing and two for determination of total nitrogen by the Kjeldahl method. (The weight of the dry residue)-(the weight of ash + weight of nitrogen $\times 6.25$ ) = amount of lignin.

\section{COMPLETE ANALYSIS OF NATURAL OR DECOMPOSED PLANT MATERIAL ${ }^{1}$}

An approximately complete analysis of a natural organic material is carried out as follows:

1. Moisture is determined on two 5-gram portions of material.

2. Total nitrogen is determined on two 2-gram portions of material.

3. Ash on two 2-gram portions.

4. Pentosans on two 2-gram portions.

5. Two 5-gram portions are analyzed as follows:

(a) Treat for 12 hours with ether in Soxhlets. The ether extract is evaporated to a small volume, then transferred to weighing bottles and dried to constant weight, giving ether soluble fraction.

(b) Residue from ether treatment is extracted for 24 hours with cold water. Extract is made up to volume and divided into four portions, one to be used for total nitrogen determination, one for determination of total soluble organic matter by evaporating in silica dishes, one for determination of reducing sugar, and one for the determination of ammonia or nitrate.

(c) Residue from cold water extraction is treated with 100 cubic centimeters hot water, boiling to be continued for 30 to 60 minutes. The solution is analyzed as in $(b)$.

${ }^{1}$ Waksman, S. A., and F. G. Tenney, Soil Sci., 24:317-341 (1927) 26 : 113-137 (1928). 
(d) The residue from the hot water extraction is now treated two or three times with boiling 95 per cent alcohol. The alcoholic solution is evaporated in a weighing bottle and dried to constant weight.

(e) The residue from the alcohol extraction is treated with 100 cubic centimeters of a 2 per cent hydrochloric acid solution and boiled under a reflux condenser for 5 to 6 hours. The solution is filtered off, through dried and weighed filter papers, and the residue is washed with dilute acid, then with distilled water, until free from acid. The filtrate and washings are now analyzed for reducing sugars, by the Bertrand method, and for total nitrogen. The amount of reducing sugar multiplied by 0.9 gives the hemicellulose content of the material.

(f) The washed residue from the hydrochloric acid extraction is dried to constant weight. Two 1-gram portions of the dry material are placed in 300-cubic centimeter Erlenmeyer flasks and treated with 10 cubic centimeters of an 80 per cent sulphuric acid solution (if the residue is compacted, it should be first well ground; if it is horny, it should have been washed with alcohol and ether, before drying), for 2 hours, in the cold. The acid must be brought in contact with all particles of the material. After 2 hours, 150 cubic centimeters of distilled water is added to each flask and contents autoclaved for 1 hour at $120^{\circ} \mathrm{C}$, or boiled for 2 to 3 hours under the reflux condenser. The contents are then filtered through small dried and weighed filter papers or through weighed Gooch crucibles. The residue is well washed with water to wash out traces of sulphuric acid. The combined solution and filtrate are analyzed for reducing sugar. The amount of glucose found multiplied by 0.9 gives the cellulose content of the material. Of the four residues for each original material, two are used for ash and two for nitrogen determinations. Weight of (residue) - (ash + nitrogen $\times$ $6.25)=$ lignin content. The cellulose and lignin found in 1 gram of residue left from the 2 per cent $\mathrm{HCl}$ extraction are now multiplied by the number of grams in this residue to give the cellulose and lignin content in the original 5 grams of material. 


\section{HUMUS DETERMINATION ${ }^{1}$}

Place six 50-gram samples of soil, previously well mixed and sieved through a 1-millimeter sieve, into six 500-cubic centimeter beakers. Add to each 50-cubic centimeters of 2.5 per cent $\mathrm{NaOH}$ solution. Place beakers in autoclave and heat for 30 minutes at 15 pounds pressure. Add 50-cubic centimeter portions of cold distilled water to each beaker, and filter the dark-colored solution through folded filter paper. After draining off all the dark solution from the soil, add again fresh portions of 50-cubic centimeters of 2.5 per cent $\mathrm{NaOH}$ solution to the same soils previously extracted, and heat again as before. Add water and filter upon the same papers. Wash soil with 50-cubic centimeter portions of hot distilled water.

The combined filtrates are collected in 500-cubic centimeter Erlenmeyer flasks and treated with a hot solution of hydrochloric acid $1: 1$, until a heavy precipitate is formed; add half as much more acid as was required to form the precipitate; warm and shake well. Filter off precipitates ( $\alpha$-fraction of soil organic matter or "humic acid") through filter papers, previously weighed and dried, or through Gooch crucibles. Wash with warm 10 per cent hydrochloric acid, then a number of times with distilled water. Dry the precipitates at 65 to $70^{\circ} \mathrm{C}$. for 24 hours and weigh. Three portions are used for ash determination and three for total nitrogen determinations. If the precipitation and washing with acid have been thorough, the ash content should not exceed 1 to 2 per cent.

The filtrate from the acid precipitate is now treated with a 5 per cent solution of $\mathrm{NaOH}$, until just neutral to litmus or until solution has reached a $\mathrm{pH}$ of 4.8 to 5.0 . A heavy precipitate will be formed in case of mineral soils. The precipitate ( $\beta$ fraction) is filtered off through a series of fresh papers, previously dried and weighed, or through Gooch crucibles. These precipitates are washed thoroughly with distilled water, dried and weighed. Three portions are used again for ash and three for nitrogen determinations. The nitrogen content of an aliquot portion of the filtrate from the second precipitate is also determined.

Tabulate results.

${ }^{1}$ Waksman, S. A., Soil Sci., 22: 221-232, 1926; Springer, U., Ztschr. Pflanzenern, Düng. Bodenk., 11A: 313-359, 1928. 


\section{CARBON DIOXIDE EVOLUTION}

Evolution of carbon dioxide from soil, to which no fresh quantities of undecomposed organic matter are added, is best determined using 1-kilogram quantities of soil. Fresh, sieved soil is placed in small unglazed porcelain pots holding just about 1 kilogram of soil. The pots are placed upon wooden bases and covered with bell jars, which are sealed down to the stand with

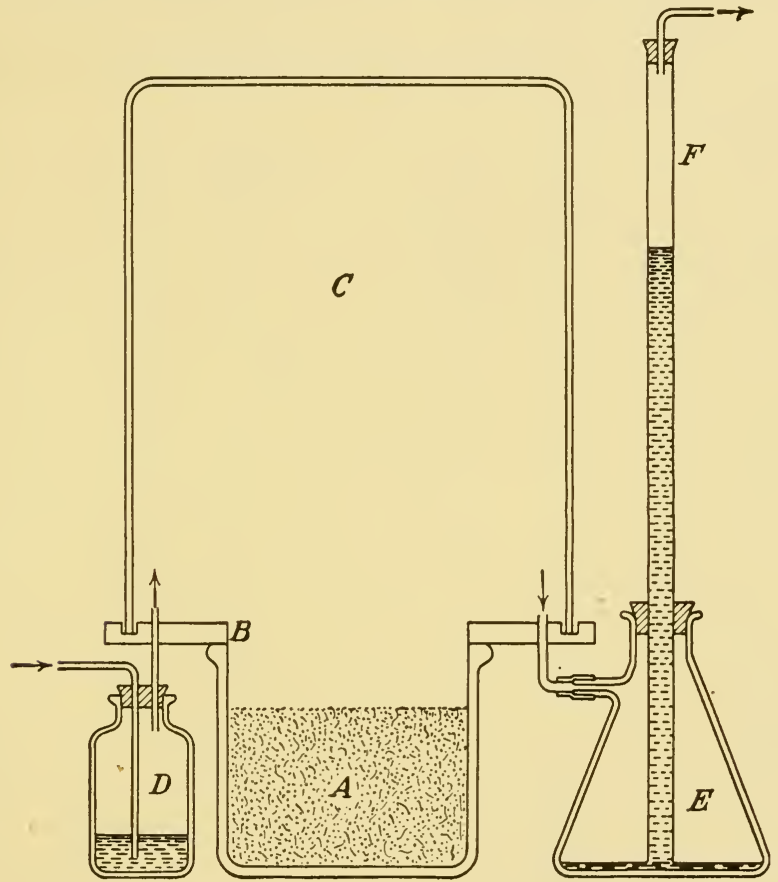

FIG. 3.-Apparatus for the study of the influence of plant growth upon the evolution of $\mathrm{CO}_{2}$ from soil. (Neller.)

paraffin. Air, freed from carbon dioxide by passing through sodalime and through bottles containing 10 per cent sulphuric acid, is drawn through the bell jars, by means of glass tubes passed through the wooden stands. The air is then drawn through absorption towers containing 50 cubic centimeters of barium hydroxide solution.

When the decomposition of fresh organic matter in soil is studied, 100-gram quantities of soil may be used. Long-necked, 
flat-bottomed flasks of 300-cubic centimeter capacity are used for this purpose. The soil and the proper amount of organic matter are introduced into the flasks; the moisture of the soil is brought to the desired concentration and the flasks connected with the respiration apparatus. The air, freed from $\mathrm{CO}_{2}$ as before, is passed through the flasks over the surface of the soil. The $\mathrm{CO}_{2}$ is absorbed in 100-cubic centimeter heavy-walled testtubes containing 25 to 50 cubic centimeters of the standard barium hydroxide solution. The excess barium hydroxide is then titrated back with standard oxalic acid solution (see also Fig. 19, Exercise 58).

\section{DETERMINATION OF TOTAL CARBON}

Total carbon can be determined by (1) the various dry combustion methods, including the bomb method (with $\mathrm{Na}_{2} \mathrm{O}_{2}$ ), and (2) wet combustion methods, using a mixture of chromic and sulphuric orchromic and phosphoric acids or permanganate and sulphuric acid. The following method was found to give very good results, especially with liquid cultures (see Fig. 4).

A definite portion of liquid culture or soil, containing not more than 100 to 120 milligrams of carbon, is placed in a 200- to 500 -cubic centimeter round-bottomed Pyrex flask ( $B$ of Fig. 4). In case of liquid materials, the water should be evaporated on a steam bath before beginning the analysis. The flask is then attached to the condenser $D$, and 10 cubic centimeters of an oxidizing solution (85 grams chromic anhydride in 100 cubic centimeters of water made up to 250 cubic centimeters with 85 per cent phosphoric acid) is introduced through the separatory funnel $C$. Gentle suction is then applied and 25 to 40 cubic centimeters of a mixture of equal parts of concentrated phosphoric and sulphuric acids are added. The stopcock in $C$ is closed and by the use of a low flame, flask $B$ is heated as rapidly as possible without developing pressure within. The gas is drawn out through condenser $D$ and through a U-tube $E$, which contains a saturated solution of $\mathrm{Ag}_{2} \mathrm{SO}_{4}$ and 5 per cent $\mathrm{H}_{2} \mathrm{SO}_{4}$ in 20-mesh pumice on the left side 1 , and boiled concentrated $\mathrm{H}_{2} \mathrm{SO}_{4}$ in 20-mesh pumice on the right side 2. The $\mathrm{Ag}_{2} \mathrm{SO}_{4}$ serves to remove the chlorine and the $\mathrm{H}_{2} \mathrm{SO}_{4}$ the $\mathrm{SO}_{3}$ fumes. The gas is then drawn through the absorption flask $F$ and absorbed in a measured quantity of $0.5 \mathrm{~N} \mathrm{NaOH}$ solution. After flask $B$ has 
been boiled gently for 15 to 20 minutes, flask $F$ is removed, the solution washed down into the flask, the carbon precipitated by the addition of an excess of $2 \mathrm{~N}$ neutral $\mathrm{BaCl}_{2}$ solution, and the excess alkali titrated with $0.5 N \mathrm{HCl}$ solution using phenolphthalein as an indicator.

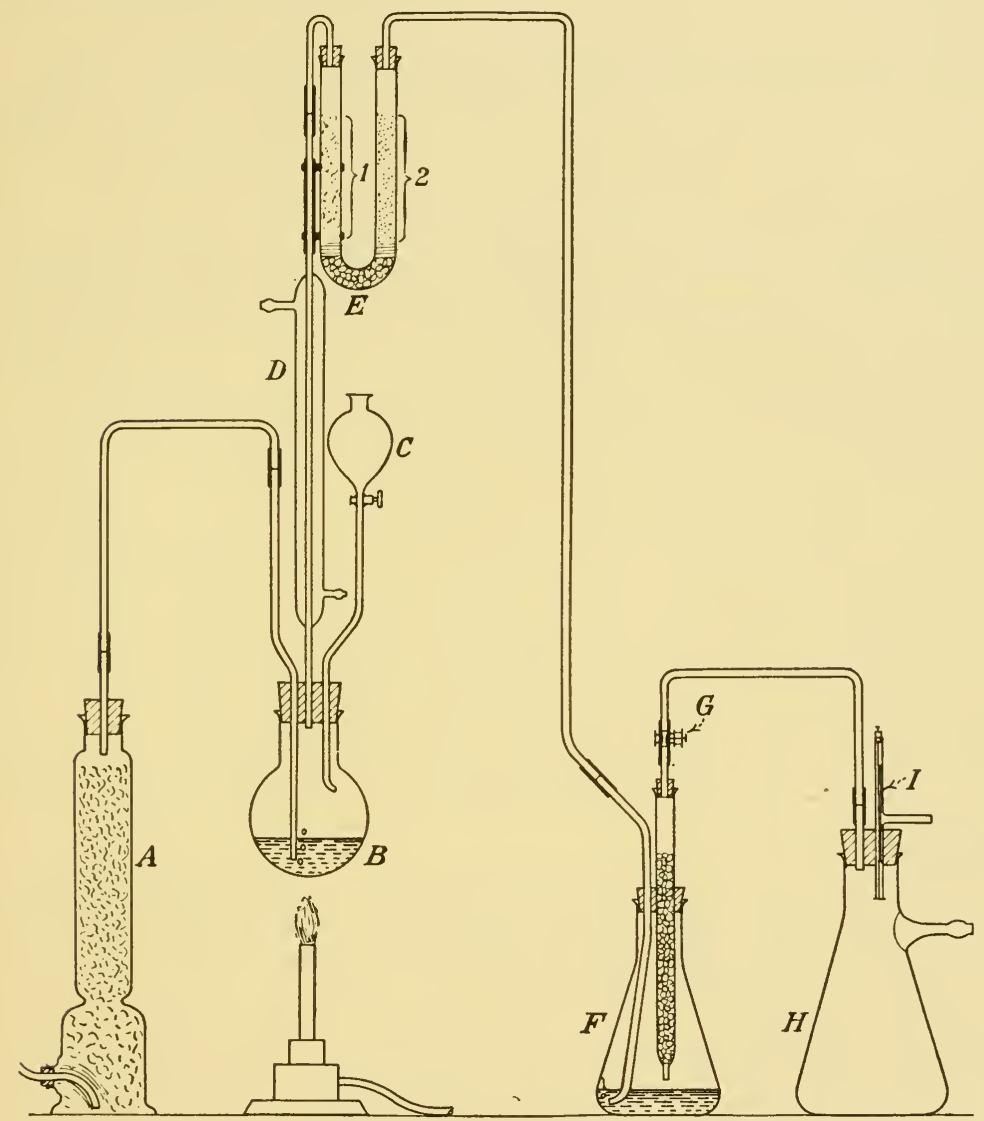

FIG. 4.-Apparatus for determination of total carbon in soil or in solution.

The absorption flask $F$ is made of a 300-cubic centimeter Erlenmeyer flask, a $1.5 \times 25 \mathrm{~cm}$. test tube, and a few glass beads. The bottom of the test tube is drawn out and while still hot the upper part of the constriction is flattened so that two beads will lie over the opening instead of one, so as to facilitate washing out. 
Suction Flask.-The suction flask $H$ is provided with a constant pressure valve $I$ which is made from small glass T-tube in which a rubber band holds a small rubber disk over the lower end. By the aid of this valve and the screw cock $G$, the flow of air can be easily regulated and should not exceed about 120 bubbles per minute.

1 cubic centimeter $0.5 \mathrm{~N} \mathrm{NaOH} \approx 3.0$ milligrams of carbon. Cubic centimeters $\mathrm{NaOH}$ added - cubic centimeters $\mathrm{HCl}$ used $\times$ $3=$ milligrams carbon.

\section{SEED STERILIZATION}

Although a great number of methods employing various agents have been recommended for removing microorganisms from seed, only a few of the more promising ones will be given. Where it is not necessary to render the seeds free of bacteria, but merely to destroy the majority of the flora, alcohol may be used.

Among the chemicals that have proved satisfactory for sterilizing seed, mercuric chloride, hypochlorite of lime, and silver nitrate are the most commonly used. The effectiveness of these substances depends on many factors: strength of solution, time of exposure, temperature, pressure, and nature of the seed coat.

Sterilization by Mercuric Chloride in Vacuum.- - Select a large heavy walled desiccator and connect to vacuum pump.

Fill test tubes or flasks about one-half full of seed, cover with 0.25 per cent solution of mercuric chloride and place in the desiccator.

Exhaust for 3 to 5 minutes depending upon the kind of seed. This should remove the air particles from around the seed coats and allow the disinfectant to come in direct contact with the seed.

At the end of this time remove the mercuric chloride solution and run in a small amount of sterile water, shake vigorously, empty, and repeat this process three or four times.

Remove some of the seed to sterile Petri dishes and pour over them a layer of nutrient agar.

After the agar hardens, invert and place in the incubator at 20 to $25^{\circ} \mathrm{C}$. In 2 or 3 days the seed should germinate. If bacteria or molds are present, they may be readily noted on the agar. 
Sterilization by Calcium Hypochlorite. ${ }^{1}-1$. Add 10 grams of commercial chloride of lime (titrating 28 per cent chlorine) to 140 cubic centimeters of water.

2. Allow the mixture to settle for 5 or 10 minutes and decant the supernatant liquid. This solution should contain about 2 per cent of chlorine.

3. For seed sterilization the solution may be diluted or used full strength. The volume of the liquid should be about five times that of the seed.

4. Place the seed in a sterile test tube and cover with a 1 per cent chlorine solution (original solution diluted one-half).

5 . The time required for sterilizing varies with the different seeds, about 6 hours for alfalfa, 8 hours for corn, and 15 hours for wheat.

${ }^{1}$ Wilson, J. K., Am. J. Bot., 2 : 420-427, 1915. 
PART IV

EXERCISES 



\title{
THE STUDY OF MICROORGANISMS IN THE SOIL
}

\author{
A. Suggested Arrangement of Class Exercises in Soil Micro- \\ biology for Course of Five Credits for one Semester \\ of 18 Weeks
}

Because of the time required for the incubation of the different groups of microorganisms, it is suggested that the exercises be given in the order listed below.

\section{Introduction}

General Characteristics of the Soil Population:
1. Bacteria.
2. Fungi.
3. Algæ.
4. Protozoa.
5. Invertebrate population of soil, non-protozoan in nature.
6. Approximate number of microorganisms in soil.

A. Microscopic examination of microorganisms:

1. Examination of living microorganisms in hanging drops.

2. Examination of bacteria in Congo red or Nigrosin preparations; of yeast and yeast spores in Erythrosin or Rose. Bengal preparations.

$B$. Methods for counting numbers of microorganisms:

3. Number of algæ in soil according to dilution method.

4. Number of protozoa according to the dilution method.

5. Number of fungi according to the plate method.

6. Number of bacteria according to the plate method (ærobic).

7. Number of anærobic bacteria in the soil.

8. Number of spore-forming bacteria in the soil.

9. Number of thermophilic bacteria.

10. Effect of season of the year on number of microorganisms.

11. Effect of plant roots on number of microorganisms.

12. Effect of depth of soil on number of microorganisms.

13. Effect of manures on number of microorganisms.

14. Dilution method for determining the number of specific physiological groups of bacteria.

15. Direct microscopic examination of soil.

16. Winogradsky's method of microscopic analysis of soil.

17. Determination of numbers of nematodes (and other worms) and insects in soil. 
C. Nitrogen-fixing bacteria and nitrogen fixation in soil:

18. The isolation of bacteria from the root nodules of various leguminous plants.

19. Cultural characteristics of root-nodule bacteria.

20. The formation of root nodules in agar and sand cultures.

21. Artificial cultures for the inoculation of leguminous plants.

22. The strueture of root nodules of leguminous plants.

23. Effect of root-nodule bacteria on the growth and the nitrogen content of alfalfa.

24. Direet method for demonstrating the occurrenee of Azotobacter in soil.

25. Isolation of Azotobacter from various soils.

26. Use of silica-gel plate for the isolation of specifie bacteria.

27. Nitrogen fixation by pure eultures of Azotobacter.

28. Effect of variation in carbohydrates on the growth of Azotobacter.

29. Anærobie nitrogen fixation (Clostridium pasteurianum and related organisms). Spore stain-Dorner modified).

30. Isolation of anærobic nitrogen-fixing organisms.

31. Nitrogen-fixing capacity of soil (Winogradsky).

32. Influence of nitrate on the fixation of nitrogen.

33. Effect of a soluble carbohydrate on nitrogen assimilation.

$D$. Denitrifying bacteria:

34. Isolation of denitrifying bacteria.

35. Denitrification by pure eultures of baeteria.

36. Denitrification in soil.

$E$. Nitrification experiments:

37. Nitrification in impure eultures.

38. Nitrification in liquid cultures (quantitative).

39. Isolation of nitrifying organisms.

40. Nitrification of various substances.

$F$. Urea and protein decomposition:

41. The deeomposition of urea with the produetion of ammonia.

42. Isolation of urea-decomposing organisms.

43. Ammonia production from various substances in soil.

44. Decomposition of an amino acid and a protein by Bac. cereus and Bact. fluorescens.

$G$. Sulphate-reducing and sulphur-oxidizing bacteria.

45. Reduction of sulphates with the formation of hydrogen sulphide.

46. Isolation of hydrogen sulphide-forming microorganisms.

47. Crude cultures of higher sulphur bacteria.

48. Oxidation of sulphur and the dissolving of rock phosphate.

49. Isolation of pure eultures of higher sulphur bacteria.

50. Growth and isolation of Thiobacillus thioparus.

51. Growth of Thiobacillus thiooxidans in liquid medium.

$H$. Iron bacteria:

52. Iron-preeipitating bacteria.

53. Iron bacteria from drinking water. 
I. Cellulose-decomposing bacteria:

54. Anærobic cellulose decomposition in impure cultures (liquid).

55. Number of ærobic cellulose-decomposing bacteria in soil.

56. The thermophilic fermentation of cellulose.

57. Isolation of cellulose-decomposing bacteria.

58. The evolution of carbon dioxide from soil.

\section{A SUGGESTED LIST OF APPARATUS FOR ONE STUDENT}

The following apparatus should be in each desk. Any omission must be reported to the instructor at once.

1 Bunsen burner and tubing

4 Wire baskets

2 Metal cups

2 Funnels

5 Erlenmeyer flasks (150 cubic centimeters)

5 Glass tumblers

10 Pipettes (1 cubic centimeter)

2 Pipettes (10 cubic centimeters)

1 Graduated pipette ( 5 cubic centimeters)

1 Thermometer

2 Platinum needles

20 Object slides (not returnable)

1 Hanging-drop slide

50 Cover glasses (not returnable)

1 Aluminum weighing dish

6 Evaporating dishes

1 Test plate

1 Wash bottle

Filter paper (8-inch)

1 Forceps (steel)

1 Spatula

1 Slide box

1 Test-tube brush

1 Towel

1 Box of matches

1 Box of labels

1 Wax pencil

1 Microscope No................. Objectives $\left\{\begin{array}{l}\text { No. } \\ \text { No } \ldots \ldots \ldots \ldots \ldots \ldots \ldots \\ \text { No } \ldots \ldots \ldots \ldots \ldots\end{array}\right.$

1 Microscope lamp

\section{LABORATORY RULES}

Read carefully the following rules:

Before pouring plates or making transfers, wash off the desk with a $1: 1,000$ mercuric chloride solution. 
Mercuric Chloride.-A stock solution is prepared and diluted to the desired strength.

Add 1 part of mercuric chloride to 2.5 parts of commercial hydrochloric acid (40 per cent $\mathrm{HgCl}_{2}$ in $\mathrm{HCl}$ ). To prepare a $1: 1,000$ solution, take 2.5 cubic centimeters of the stock solution and dilute to 1,000 cubic centimeters. Color with dye and label "poison."

Transferring Cultures.-Hold the test-tube cultures to be transferred as nearly in a horizontal position as possible. Avoid opening cultures in a current of air.

All cultures are to be grown in the incubator at $28^{\circ} \mathrm{C}$. unless otherwise stated.

Care of Apparatus.-After using balances, always return weights to their proper places. Do not leave any dust or dirt on balances.

All solid material, as soil, agar, cotton or filter paper, must be emptied into waste jars and not into the sinks.

Soil should not be sieved in the laboratory. The greenhouse or potting room may be used for this purpose.

At the end of the laboratory period return all stock bottles and chemicals to their proper places on the shelves. See that all apparatus is replaced in the lockers and that all gas burners are shut off. Wipe off the table top before leaving.

Anything left on the desk will be collected after the laboratory period and returned to the store room.

Cleaning Glassware.-All glassware must be thoroughly cleaned before it is ready to use. Test tubes, Petri dishes, flasks, and similar glassware should be boiled in a 5-per cent soda solution or washed in hot soapsuds until free from organic matter. When it is desirable to use very clean glassware, immerse for 10 minutes or longer if possible in the dichromate solution.

$$
\begin{aligned}
& \text { Potassium }\left(\mathrm{K}_{2} \mathrm{Cr}_{2} \mathrm{O}_{7}\right) \text { or sodium dichromate }\left(\mathrm{Na}_{2} \mathrm{Cr}_{2-}\right.
\end{aligned}
$$

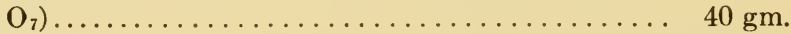

$$
\begin{aligned}
& \text { Water............................... } 150 \text { cc. } \\
& \text { Sulphuric acid }\left(\mathrm{H}_{2} \mathrm{SO}_{4}\right) \ldots \ldots \ldots \ldots \ldots \ldots \ldots \ldots \ldots \ldots \ldots \text { cc. }
\end{aligned}
$$

Note.-Dissolve the dichromate in warm water and, when cool, add slowly concentrated sulphuric acid. If properly prepared, the liquid should be thick, with small crystals. It may be used repeatedly, provided the crystals are present. 
After removing glassware from the cleaning solution rinse thoroughly in distilled water.

Dirty cover glasses and slides may be treated in the same manner. Drop these, one at a time, into the dichromate mixture and allow to remain for several hours. Remove from this solution, wash, and wipe with a soft, clean cloth.

A simple and more rapid method, suitable for general work, is to rub the slides with moist Bon Ami, and when dry polish them with a clean cloth.

In order to remove fat, pass the cover slips through a flame. Where it is desirable to have very clean slides and cover slips, it is well to heat them in water and then in 50 per cent sulphuric acid. After rinsing in distilled water, wash in alcohol and wipe with a clean cloth. These should be kept in a clean, covered dish.

\section{A Black Finish for Table Tops}

Method-I

The following solutions are required:
A. Copper sulphate
$125 \mathrm{gm}$.
Potassium chlorate................. $125 \mathrm{gm}$.
Water...................... 1,000 cc.
Boil until salts are ciissolved.

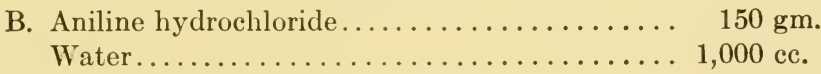
Or, if more readily procurable:
Aniline oil................... $120 \mathrm{gm}$.
Hydrochloric acid................ $180 \mathrm{gm}$.
Water......................... 1,000 cc.

By means of a brush apply two coats of solution A while hot, the second coat as soon as the first is dry. Then apply two coats of solution B and allow the wood to thoroughly dry. A coat of raw linseed oil is next applied. It is best to use a cloth instead of a brush so as to get only a very thin coat of oil. The desired amount of polish is now given the wood by rubbing in the oil. In the treatment with the oil the deep black color is partially brought out, although this does not uniformly appear until the table has been thoroughly washed with hot soap suds. This takes out the superfluous chemicals.

The finish thus secured is an ebony black which is permanent and very highly resistant to the action of chemicals, such as acids and alkalies, even concentrated sulphuric acid having little or no effect if quickly washed off. 


\section{Method II}

The following solutions are required:

A. Aniline................... $120 \mathrm{gm}$.

Hydrochloric acid (commercial)........ $180 \mathrm{gm}$.

Water....................... 1,000 cc.

B. Sodium dichromate.............. $120 \mathrm{gm}$.

Hydrochloric acid................ $100 \mathrm{gm}$.

Water....................... 1,000 ce.

Solution A should be applied with a brush to the fresh smooth surface and allowed to dry overnight. The color will turn bright yellow. Solution B should then be spread on the wood, which will turn dark and be very streaky at first. After this second coat dries the surface should be rubbed with vaseline, motor oil, or paraffin. Vaseline seems to be preferable.

\section{GENERAL CHARACTERISTICS OF THE SOIL POPULATION}

Every particle of soil harbors numerous microorganisms, which vary in kind, nature of nutrition and, therefore in the biochemical processes which they bring about. Although one set of conditions may favor the activities of one group of organisms in preference to others, no soil is known in which only a single species of one organism is found. The actual number of cells may vary from a few hundred thousands per gram in certain very poor sandy soils and in bog soil to many billions in good garden, field, and greenhouse soils. The number of species varies from a few types of fungi and bacteria in marshy lands or in very acid forest. soils to thousands of species in the garden and field soils.

The soil population can be readily divided into the following 5 groups:

1. Bacteria.-This group is usually the most numerous in the soil, both in the total number of cells and in the number of species. Morphologically, they comprise the cocci, non-spore forming and spore-forming bacteria and spirilla. Some bacteria, forming thin, long, flexuous, undulating cells are often referred to as Spirochætes, but these soil forms belong to the bacteria rather than to the protozoa. These numerous soil bacteria vary considerably in their nutrition and in their response to environmental conditions. We have ærobic and anærobic forms, autotrophic and heterotrophic bacteria, those that are resistant to acids and those that do not grow at a pH less than 6.0. The 
nature and abundance of the various types of bacteria thus depends both upon the available nutrients present in the soil and upon the soil environmental conditions, such as reaction, æration, moisture content, abundance of organic matter, etc. The plate method of counting gives only a fraction of the total number of bacteria present in a given soil. This is due to the fact that the many types of bacteria such as the autotrophic, anærobic, nitrogen-fixing ones, etc., do not develop on the common media.

2. Fungi.-Although the bacteria from the largest group of organisms in most soils, the fungi may be present in considerably greater bulk in some soils, such as acid forest soils or heavily manured, acid garden and field soils. This is due to the considerable difference in size of a piece of fungus mycelium and a bacterial cell. The abundance of fungi in the soil can be determined both by the plate and the microscopic methods. A colony may develop either from a spore or from a piece of mycelium. Spore fungi, like most Hyphomycetes, form a mycelium which readily breaks up into fragments. Others, like the Phycomycetes form a unicellular mycelium. In the case of these organisms, the number of colonies developing on a plate may be far from representing their actual abundance. The fungi are represented in the soil by $(a)$ the filamentous fungi or molds, $(b)$ the actinomyces, or ray fungi, and $(c)$ the yeasts. In acid forest soils, there is an extensive development of fungus mycelium, belonging to Basidiomycetes and other fungi, which do not readily form any fruiting bodies. Many of these produce "mycorrhiza" with the roots of various trees, and a number of other perennial and annual plants. The relative abundance of these fungi can be obtained only by the aid of the microscope.

3. Algæ.-The chlorophyll-bearing microscopic plants do not need any carbon compounds as sources of energy. They obtain from the soil only nitrogen and minerals while the carbon is derived from the $\mathrm{CO}_{2}$ of the atmosphere, using photosynthetic energy. The algæ are represented in the soil by the (a) Cyanophyceæ, or blue-greens, (b) Chlorophyceæ, or grass-greens, (c) and Diatomaceæ, or diatoms. Many of the algæ are able to live at lower depths of soil and are capable of obtaining their carbon and energy from complex organic compounds. The number of algæ in the soil is best determined by the dilution method. 
4. Protozoa.-Many of these organisms feed upon bacteria, and their development depends upon the abundance of bacteria. Some of the protozoa, like the ciliates and amoebæ, are large in size, and they may form a considerable quantity of living or recently living protoplasm in the soil. The protozoa are represented in the soil by the $(a)$ flagellates, $(b)$ amoebæ, and $(c)$ ciliates which are usually less numerous than the other two groups.

\section{Invertebrate Population of Soil, Non-protozoan in Nature.-} This group is represented in the soil by the (a) Nematodes, or round worms, which may be present in hundreds of millions per acre of soil, (b) Rotifers or wheel animalcules, (c) Turbellarians, or flat worms, $(d)$ Trematodes, or flukes, (e) Annelids or segmented worms, including the earthworms, $(f)$ Arachnids, including the mites, ticks, and spiders, $(g)$ Myriapodes, $(h)$ insects, etc.

The relative abundance of these organisms per gram of soil can be shown as follows:

Approximate Number of Microorganisms in Soll

\begin{tabular}{|c|c|c|c|}
\hline & $\begin{array}{l}\text { Numbers, } \\
\text { plate } \\
\text { method in } \\
1 \text { gram }\end{array}$ & $\begin{array}{l}\text { Numbers, } \\
\text { microscopic } \\
\text { method in } 1 \\
\text { gram }\end{array}$ & $\begin{array}{l}\text { Approximate size, } \\
\text { in microns }\end{array}$ \\
\hline \multicolumn{4}{|l|}{ Bacteria: } \\
\hline Minimum. & 100,000 & $10,000,000$ & $0.3-2 \times 0.4-10$ \\
\hline Maximum. & $100,000,000$ & $10,000,000,000$ & \\
\hline \multicolumn{4}{|l|}{ Fungi: } \\
\hline Minimum. & 1,000 & a few & $3-10 \times 3-100$ \\
\hline Maximum.. & $20,000,000$ & $50,000,000$ & \\
\hline \multicolumn{4}{|l|}{ Actinomyces: } \\
\hline Minimum. . & & & $0.5-2.0 \times 0.5-50$ \\
\hline Maximum.. & $40,000,000$ & & \\
\hline \multicolumn{4}{|l|}{ Algæ: } \\
\hline Minimum. . & a few & & $1.5 \times 2-50 ?$ \\
\hline Maximum.......... & 500,000 & & \\
\hline \multicolumn{4}{|l|}{ Protozoa: } \\
\hline Minimum. & 10,000 & & $2-10 \times 5-200$ \\
\hline Maximum......... & $2,000,000$ & & \\
\hline $\begin{array}{l}\text { Invertebrates (non-pro- } \\
\text { tozoan) per acre, up to.. }\end{array}$ & $500,000,000$ & & 100 to 2,000 \\
\hline
\end{tabular}


The microorganisms are responsible for the various biochemical processes going on constantly in the soil and which lead to the liberation of nutrients essential for the growth of higher plants. These nutrients include the carbon, as carbon dioxide, the nitrogen as ammonia and nitrate, the minerals, especially phosphorus and potassium. The following exercises are planned to show how the microorganisms liberate those nutrients, as well as the nature of the organisms themselves and methods of study.

\section{MICROSCOPIC EXAMINATIONS OF MICROORGANISMS}

\section{Exercise 1}

Examination of Living Microorganisms in Hanging Drops

Place a small drop of the liquid to be examined in the center of a cover glass without spreading. Smear vaseline around the concavity of a hollow-ground slide and invert this slide over the cover glass with the drop so that the cover glass adheres to the slide. Turn over the slide and see that the drop does not touch the slide. Examine the hanging drop with a low- and then with a high-power objective. To secure the best results reduce the illumination. The addition of a small amount of nigrosin (saturated aqueous solution of nigrosin B) to the hanging drop makes the bacteria stand out as clear spots in a dark background. It is advisable to focus on the edge of this drop.

While this method of examination is primarily for detecting motility and Brownian movement, it is useful in a study of general morphology.

Examine: 1. Hay infusion.

2. Pure culture of yeasts and bacteria.

\section{Exercise 2}

A. Examination of Bacteria in Congo Red or Nigrosin Preparations

This method of examination as described below has many advantages; it is rapid and does not alter the size of the organisms. It is especially useful for liquid cultures. The bacteria appear as clear spots in a dark background. If Congo red is used the dead cells appear as faintly colored, the living as colorless. Because 
of contamination which may be present in the dye solutions it is always well to mount a drop of the uninoculated dye on the same slide.

Examine: Cultures of bacteria from hay infusion, $B$. subtilis or B. mesentericus.

\section{Congo Red for Negative Mounts :}

(For differentiating living and dead bacteria.)

(a) Place a drop of 2-per cent aqueous Congo red solution (free of bacteria) on a clean glass slide.

(b) Mix with it a loopful of the bacterial culture.

(c) Allow it to dry thoroughly in air 10 minutes or more.

(d) Flood with acid-alcohol (1- or 2-per cent $\mathrm{HCl}$ ). This changes the color to blue and fixes the film.

(e) Dry without washing and examine in oil, with or without cover glass. Living cells appear unstained-white against blue.

Unless preserved with oil or balsam the preparations fade rapidly.

This method of preparing negative mounts is recommended for root-nodule bacteria. The active living cells are negative while the dead cells are more or less positive.

\section{Nigrosin for Negative Mounts :}

(a) Place a loopful of culture on a clean glass slide, spread, and allow it to air dry.

(b) Spread thinly over the smear a loopful of saturated aqueous solution of nigrosin $B$. Spread either with the wire loop or with a glass slide (as for blood smears). Dry and examine in oil, or mount in Canada balsam.

By the use of nigrosin it is possible to examine organisms unstained. There are many points in favor of this method, e.g., the organisms do not shrink or change their form.

B. Examination of Yeasts and Yeast Spores in Erythrosin or Rose Bengal Preparations

In a drop of sterile water on a glass slide, mix a small amount of the yeast culture.

Add a large loop of Erythrosin or Rose Bengal (0.5 gram in 100 cubic centimeters of water). The dead cells stain a deep pink while the living cells remain colorless.

To prevent evaporation make a ring of vaseline around the edge of the drop culture and place cover slip over the top. 
Examine under high-dry and oil-immersion lenses. Make drawings.

\section{METHODS FOR COUNTING NUMBERS OF MICROORGANISMS}

Directions for Drawing Soil Samples.-Samples from the surface to 1 foot deep may be taken as follows: Remove the coarse surface debris and sink a metal cylinder or soil sampler to the desired depth. Samples of surface soil may be taken with a sterile spatula. Draw several samples and empty into sterilized paper bags or other vessels. Mix and pulverize the sample. This may be done with a sterile spatula upon a large piece of sterile paper. From the well-mixed sample remove a representative portion for dilution, and at the same time make a moisture determination.

When it is necessary to secure accurate samples from various depths, it is well to dig a ditch to the desired depth. By means of a sterile trowel, representative samples may be drawn from the sides of the ditch. In this way outside contamination is largely prevented.

In order to reduce the error common to determinations of this character, it is well to use a large sample of soil. Balances sensitive to 10 milligrams are satisfactory for this work.

\section{Exercise 3}

Number of Alge in Soll according to Dilution Method

Add 50 grams of soil to 500 cubic centimeters of sterile water and shake vigorously for 5 minutes.

After the coarse particles have settled, dilute as follows:

(a) Add 10 cubic centimeters of soil suspension to 90 cubic centimeters of sterile water, giving a dilution of $1: 100$.

(b) Add 10 cubic centimeters of dilution (a) to 90 cubic centimeters of sterile water, giving a dilution of $1: 1,000$. If the soil is rich it is well to increase the dilutions.

Inoculate one flask of algal medium (Medium 42 and 43) with 1 cubic centimeter of each of the above dilutions.

The cultures should be kept near a window. Note when green color appears, usually 30 to 90 days. Examine in wet mounts.

Calculate the number of algæ in 1 gram of soil. 


\section{Exercise 4}

Number of Protozoa according to the Dilution Method

Add 50 grams of surface soil to 500 cubic centimeters of sterile water, as directed in the preceding exercise.

After the coarse particles have settled, dilute as follows:

(a) Add 10 cubic centimeters of the soil suspension to 90 cubic centimeters of sterile water; dilution 1:100.

(b) Add 10 cubic centimeters of dilution (a) to 90 cubic centimeters of sterile water; dilution 1:1,000.

(c) Add 10 cubic centimeters of dilution (b) to 90 cubic centimeters of sterile water; dilution 1:10,000.

(d) Add 10 cubic centimeters of dilution (c) to 90 cubic centimeters of sterile water; dilution 1:100,000.

Inoculate duplicate tubes containing liquid media, using hayextract (Medium 38), soil extract (Medium 40), or any medium adapted to protozoa. Nutrient agar placed in dishes may also be used.

Incubate the protozoan cultures at room temperature.

At intervals of 2 days each, make a microscopic examination of the cultures. Since the protozoa are usually larger than bacteria-the 16 millimeters, or two-thirds, and 4 millimeters, or one-sixth objectives will be found desirable.

By means of a large-mouthed pipette or loop, transfer a small portion of the protozoan culture to a slide and examine. A wet or hanging-drop mount may be used. In certain cases the small flagellates become so numerous that it is difficult to distinguish between the bacteria and protozoa.

If it is desired to differentiate between the number of vegetative cells of protozoa and number of cysts, another 50 grams of soil may be treated with 200 cubic centimeters of a 2 per cent solution of hydrochloric acid and allowed to stand over night. The next morning 300 cubic centimeters of water are added and dilutions made as before. The treatment with acid results in the destruction of the vegetative cells and thus the number of protozoan cysts may be obtained.

\section{Exercise 5}

Number of Fungi according to the Plate Method

Add 50 grams of soil to 500 cubic centimeters of sterile water. Shake vigorously for 5 minutes. 
After the coarse particles have settled, dilute as follows:

(a) Add 10 cubic centimeters of soil suspension to 90 cubic centimeters of sterile water; dilution 1:100.

(b) Add 10 cubic centimeters of dilution (a) to 90 cubic centimeters of sterile water; dilution $1: 1,000$.

(c) Add 10 cubic centimeters of dilution (b) to 90 cubic centimeters of sterile water; dilution 1:10,000.

(d) Add 10 cubic centimeters of dilution (c) to 40 cubic centimeters of water; dilution $1: 50,000$.

From dilutions $(b),(c)$, and $(d)$, of $1: 1,000,1: 10,000$ and $1: 50,000$, pour plates in triplicate.

Add to each plate about 10 cubic centimeters of the peptonesucrose-agar, Medium 18, melted and cooled to $40^{\circ} \mathrm{C}$.

Incubate at $28^{\circ} \mathrm{C}$. and count after 2 and 4 days.

\section{Exercise 6}

Number of Bacteria according to the Plate Method (ærobic)

Weigh 50 to 100 grams of soil on a piece of paper or scoop. Transfer the soil to a 500- or 1,000-cubic centimeters sterile water blank.

Five hundred cubic centimeters of water in a 750-cubic centimeter Erlenmeyer flask allows ample space for shaking (tap water may be used). For ordinary work, provided the blanks are not stored for a long time, sterilization of the water blanks for 30 minutes in the steamer will be sufficient for use in soil counts. Some prefer sterilization in the autoclave for 15 minutes at 15 pounds' pressure.

Shake the soil suspension vigorously for at least 5 minutes and allow the coarse particles to settle.

Add 10 cubic centimeters of this first dilution (equivalent to 1 gram of soil) to a 90 -cubic centimeter sterile water blank.

After shaking, add 1 cubic centimeter to a 99-cubic centimeter sterile water blank (dilution $1: 10,000$ ).

Transfer 1 cubic centimeter of the above to a 9-cubic centimeter sterile water blank. As a rule, this dilution, which represents 1:100,000 of a gram of soil to each cubic centimeter, is the one from which to pour plates. If the soil is very poor, use a dilution of $1: 10,000$; if very rich, 1:1,000,000. The number of dilutions will depend on the type of soil. Garden or 
well-cultivated soil rich in organic matter requires a higher dilution than poor, sandy soil.

According to the total number of bacteria pour plates from the dilutions $1: 10,000,1: 100,000$ and $1: 1,000,000$. In general dilutions of about $1: 100,000$ are satisfactory. About 5 to 10 parallel plates for each dilution should be poured.

Add to each plate about 10 cubic centimeters of the agar medium (Mediums 4 or 5), melted and cooled to about $45^{\circ} \mathrm{C}$. A blank plate or control should be poured with each series. In case the medium is turbid, heat slowly, allowing the deposit to

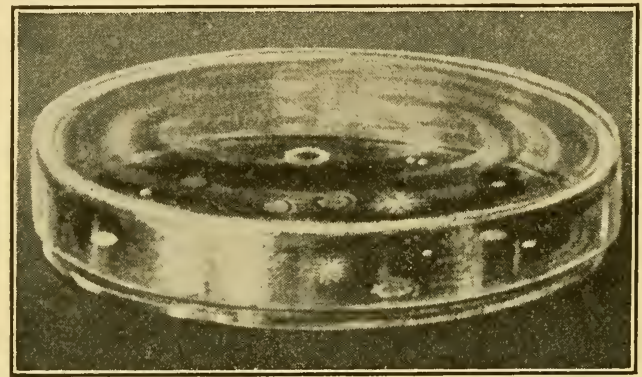

FIG. 5.-Colonies of bacteria and fungi on Petri dish. (Löhnis and Fred.) settle. Use only the clear portion of the medium for pouring plates.

Immediately after adding the culture medium, rotate each plate to secure a uniform mixture. Allow agar plates to harden on a level surface for at least 30 minutes.

Agar plates should be inverted and incubated under a moist chamber at $28^{\circ} \mathrm{C}$. The time of incubation will depend upon the microorganisms and the medium. After 5 to 10 days count the number of colonies on each plate. If the colonies are not too thick, it is well to dot each one with a pen and ink. When the colonies are too thick to count easily, use a hand lens and counting plate.

Reduce all results to number of bacteria in 1 gram of dry soil.

\section{Exercise 7}

Number of Anærobic Bacteria in the Soll (Optional)

Prepare a series of dilutions of soil in sterile tap water as previously outlined. Dilutions equal to $1: 1,000$ and $1: 10,000$. 
One-cubic centimeter portions of the final dilutions are added to 15 cubic centimeters of a sterile specific agar medium (e.g., glucose agar for Clostridium pasteurianum, Medium 11 or 12).

To remove oxygen from the medium steam for about 30 minutes just before it is to be used. Now cool to $45^{\circ} \mathrm{C}$. and add the dilutions of soil, mixing well the soil suspension with the agar by rotating the tube. The deep agar tube will produce anærobic conditions favorable for the development of the specific organisms.

The colonies may be counted in the tube, after a definite period of incubation ( 7 to 14 days).

Liquid media, incubated under anærobic conditions may be employed.

If it is desired to determine the number of anærobic bacteria present in the form of spores and vegetative cells, one portion of soil is suspended in water and heated at $80^{\circ} \mathrm{C}$. for 10 minutes, which results in the destruction of the vegetative cells; the further dilutions are then prepared from the first suspension.

If the colonies are to be isolated for pure culture study, allow the agar medium to solidify and then pour on the surface of the agar in the tubes or plates a layer of agar containing 0.05 per cent of $\mathrm{HgCl}_{2}$, about $1 / 2$ centimeter in thickness.

\section{Exercise 8}

Number of Spore-forming Bacteria in the Soll

Prepare water suspensions of the soil as described in Exercise 6 , making dilutions of $1: 1,000,1: 10,000$, and $1: 100,000$.

Transfer 10 cubic centimeters of each suspension to a sterile test tube. Heat these inoculated tubes for 10 minutes at $80^{\circ} \mathrm{C}$. Cool quickly under the tap.

Place in Petri dishes 1 cubic centimeter portions of each of the unheated and heated dilutions. Use three plates for each dilution.

Pour plates of sodium caseinate or nutrose agar (Medium 4) and incubate at $28^{\circ} \mathrm{C}$.

After 7 to 10 days count the number of colonies.

\section{Exercise 9}

Number of Thermophilic Bacteria (Optional)

Incubate several samples of soil and some fresh stable manure at $60^{\circ} \mathrm{C}$. 
In order to prevent evaporation all samples must be kept in a moist chamber. A large glass beaker or metal container may be used. Avoid glass bell jars, unless of Pyrex glass, since the high temperature may cause them to crack.

After 1 week in the incubator, prepare agar plates from the different samples. Pour from dilutions 1:1,000 and 1:10,000.

The plates must be incubated at $60^{\circ} \mathrm{C}$.

Determine the number of thermophilic bacteria in 1 gram of soil.

If desirable, a study may be carried on of the bacteria growing at low temperatures.

\section{Exercise 10}

Effect of Season of Year on Number of Bacteria

Collect samples of soil from an alfalfa field, clover field, bluegrass field, orchard sod, etc. If the soil is frozen, it will be necessary to use a pick or hatchet in securing samples.

Prepare dilution plates as soon as possible after the samples reach the laboratory. Unless the soil is very rich use dilutions of $1: 10,000$ and $1: 100,000$, about four or five parallel plates for each dilution.

At the same time plates are poured, make moisture determinations of the soil.

Record outside temperature and also soil temperature at the time samples are drawn. Read the directions given in Exercise 6.

\section{Exercise 11}

Effect of Plant Roots on Number of Microorganisms

Collect soil samples from the immediate vicinity of the roots of various plants (alfalfa, clover, etc.), and similar samples 1 or 2 feet away from the plants.

Determine the number of bacteria by means of plate counts.

\section{Exercise 12}

Effect of Depth of Soll on Number of Microorganisms

The samples for this exercise should be drawn from virgin soil well removed from any source of contamination. The type of soil will determine to a certain degree the number of organisms at different depths. 
Divide the sample of soil, taking one portion for plate count, the other for moisture determination. For virgin field soil the following dilutions have been found satisfactory.

Take soil samples and plate as follows:

\section{Bacteria Fungi}
(a) Surface soil
$1: 100,000$
$1: 10,000$
(b) Soil 1 foot deep
$1: 10,000$ and
$1: 1,000$
$1: 100,000$
(c) Soil 2 feet deep................ 1:1,000 and
$1: 100$
$1: 10,000$
(d) Soil 4 feet deep
$1: 100$ and
$1: 1,000$

Follow the method given in previous exercises. Tabulate results.

\section{Exercise 13}

Effect of Manures on Number of Microorganisus

Prepare five tumblers or beakers with 100 grams each of field soil.

Arrange as follows:

(a) Control. No treatment.

(b) Treat with 1 per cent of finely chopped green clover.

(c) Treat with 1 per cent of well-rotted stable manure.

(d) Treat with 1 per cent of ground wheat or rye straw.

(e) Treat with 1 per cent of ground wheat or rye straw and 0.1 per cent $\left(\mathrm{NH}_{4}\right)_{2} \mathrm{HPO}_{4}$.

Since these substances contain great numbers of bacteria, especially the stable manure, plate counts should be made of the manures at the time the soils are treated. For this purpose shake 5 -gram portions of the manures with 5 cubic centimeters of sterile water. Dilute as given in the previous exercises. Pour plates from the dilutions $1: 100,000$ and $1: 1,000,000$ for bacteria and $1: 10,000$ for fungi.

After mixing thoroughly the soil and manure in tumblers, raise the moisture to two-thirds saturation.

Cover the soil with Petri dishes and incubate at room temperature.

Determine the number of bacteria and fungi after 1 and 3 weeks. 
Before drawing the sample for counts mix the contents of the tumblers thoroughly. This may be done with a sterile spatula. In the case of treated soils plate from the dilutions 1:100,000 and $1: 1,000,000$ for bacteria, and $1: 10,000$ and $1: 100,000$ for fungi.

\section{Exercise 14}

Dilution Method for Determining the Number of Specific Physiological Groups of Bacteria

This method is based upon the growth of different groups of organisms upon specific substrates.

Prepare a series of dilutions of soil in sterile tap water, as $1: 10$, $1: 100,1: 10,000$, etc., and add two 1-cubic centimeter portions of the final dilutions to flasks or tubes containing the desired liquid medium or to plates containing the desired agar, gelatin or silica-gel medium.

For example: For the determination of the number of Azotobacter in soil, a medium free from nitrogen, containing mannitol as a source of energy and of a $\mathrm{pH} 7.0$ to 9.0 is used. For the determination of the number of urea bacteria, a medium containing 2 to 5 per cent of urea as the only source of energy and nitrogen is used. To determine the number of nitrite forming bacteria, a medium containing an ammonium salt and $\mathrm{CaCO}_{3}$ or $\mathrm{MgCO}_{3}$ is employed.

\section{Exercise 15}

\section{Direct Microscopic Examination of Soll ${ }^{1}$}

Make a suspension of soil in nine times its weight of a 0.015 per cent solution of gelatin.

Smear a drop of this in a thin film on a slide and dry. (Both the amount used and the size of the smear must be measured if the number of bacteria is to be counted.)

Immerse for 1 to 3 minutes in a 40 per cent solution of acetic acid or a $0.1 N$ solution of hydrochloric acid. Wash off the excess acid quickly, and dry on a flat surface over a boiling water bath.

While still on the water bath cover the film with a 1 per cent aqueous solution of Rose Bengal, or Erythrosin, and allow it to stain for about 1 minute.

${ }^{1}$ Conn, H. J., "Stain Technology," 1: 125, 1926; Soil Sci., 26: 257, 1928. 


\section{Exercise 16}

Winogradsky's Method of Microscopic Analysis of Soll

Take several soil samples, mix carefully, and powder. Add 1 gram of soil (on dry basis) to 4 cubic centimeters of distilled water and shake vigorously for 5 minutes.

Allow to settle for 30 seconds, then pour off suspension into small tube of hand centrifuge.

Add twice 3-cubic centimeter portions of water to residue, shake 1 minute, allow to settle for 30 seconds and pour into same tube of centrifuge. These manipulations take about 10 minutes. The combined extract ( 10 cubic centimeters) has in the meanwhile formed another sediment.

Pipette off 5 cubic centimeters of the supernatant liquid into another centrifuge tube and again centrifuge a few minutes; a third sediment is formed.

Stained preparations are then made of the three sediments, of the centrifuged and non-centrifuged suspensions.

A drop is placed upon a slide, to cover 1 square centimeter.

Dry in oven and cover with a small portion of 1 per cent warm agar solution or 0.1 per cent cold agar solution.

When the agar has dried, a few drops of absolute alcohol are added to fix the preparations.

This is followed by staining with a 1 per cent solution of Erythrosin in 5 per cent phenol solution, allowing the dye to act for 5 to 15 minutes in the cold or slight warming, then washing a few seconds in water. Attempt to differentiate between short rods and cocci, bacilli, Azotobacter cells, spores and filaments of fungi, actinomyces filaments, and protozoan cysts.

\section{Exercise 17}

Determination of Numbers of Nematodes and Other Worms and INSECTS IN SoIL ${ }^{1}$

Obtain several soil sampling tubes consisting of open cylinders (made of tin or galvanized iron), 72.1 millimeters of internal diameter, with the rim of one end sharpened and the other reinforced. The area of the internal cross-section of the tube is

${ }^{1}$ Совв, N. A., Bur. Pl. Ind., U. S. Dept. Agr., Agr. Tech. Circ., 1, 1918. 
just one-millionth of an acre. The tubes are usually 6 to 9 inches long.

By means of this tube, several samples are obtained from different parts of the field. The soil of the various samples is then well mixed and sifted.

An aliquot portion of soil is then suspended in 10 to 20 volumes of water and well shaken.

The heavy particles of soil are allowed to settle for 5 seconds and the supernatant liquid immediately poured into another vessel.

The residue is washed two or three times with clean water and the washings added to original liquid.

The liquid is allowed to run through a series of superimposed sieves, ranging from 16- to 200-mesh per inch and the residual material is washed with a little water. When the liquid flowing through the finest sieve shows no animals, it is discarded.

The animals are washed away from each sieve with a small amount of water and washings with animals placed in a series of tubes.

The animals settle more readily to the bottom than the clay. The suspended liquid can be removed after 30 minutes' settling and replaced by clean water. The mixture of inorganic particles and organisms is then examined under the microscope.

\section{NITROGEN-FIXING BACTERIA}

Exercise 18

The Isolation of Bacteria from the Root Nodules of Various Leguminous Plants

Thoroughly wash the roots and nodules of several leguminous plants (e.g., red clover, alfalfa or sweet clover, pea or vetch, and soybean) under the tap.

Compare the number, size, color and position of the nodules on the roots of these different leguminous plants.

Select a large and firm nodule, cut off, and immerse for 3 to 5 minutes in mercuric chloride solution $(1: 1,000)$, or in 70 per cent alcohol. Remove alcohol or mercuric chloride by washing in sterilized water and place the nodule on a sterile surface (flamed slide or Petri dish). 
If the nodule is small, crush, if the nodule is large, cut open with a sterile knife and press out some of the inner contents into a drop of sterile water.

Make two or more loop transfers from the first drop of water in a Petri dish to a second containing a few drops of water.

Repeat these dilutions to a third and fourth Petri dish. Pour Congo red mannitol agar plates (1 liter of Medium $79+10$ cubic centimeters of a solution of 1 gram of Congo red in 400 cubic centimeters water), agitate until thoroughly mixed and incubate at $28^{\circ} \mathrm{C}$.

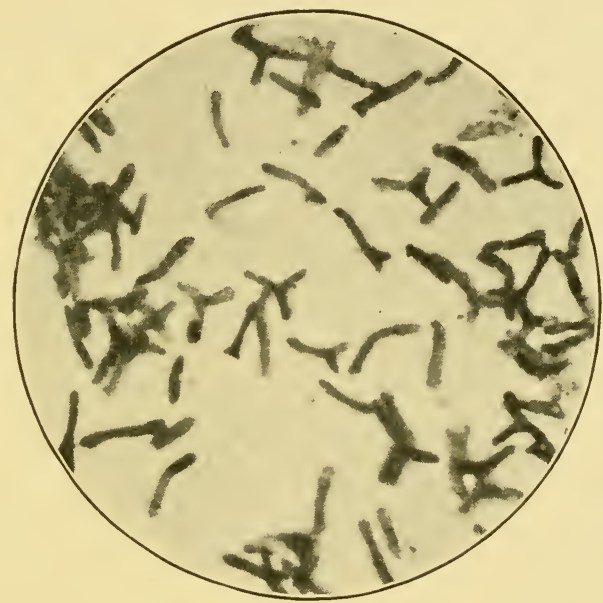

FIG. 6.-Bacteria from the nodules of pea $(X 1,500)$, stained with dilute carbolfuchsin.

Instead of diluting in the melted agar, a suspension of the bacteria may be spread over the surface of hardened agar.

After 5, 10 and 20 days examine the plates. Fish off pure cultures and transfer to slopes of Brom thymol blue mannitol agar. Select about 5 pure cultures for each plant. The root nodule bacteria usually form raised moist surface colonies, with round edges, at first glistening, later changing to an opaque white.

Prepare stained mounts of the root nodule bacteria.

1. Fuchsin (carbol, according to Ziehl). Dilute with distilled water, 1 part of stain and 9 parts of water. 


\section{Erythrosin}

(a) Erythrosin $\ldots \ldots \ldots \ldots \ldots \ldots \ldots \ldots \ldots \ldots, \quad 5.0 \mathrm{gm}$.

Alcohol $(70$ per cent $) \ldots \ldots \ldots \ldots \ldots \ldots \ldots, 100.0 \mathrm{cc}$.

(b) Erythrosin.................... $1.0 \mathrm{gm}$.

Carbolic acid (5 per cent) $\ldots \ldots \ldots \ldots \ldots \ldots, 100.0$ cc.

This stain is especially recommended for root nodule bacteria.

1. Place a drop of the fresh culture on a glass slide, tilt the slide to allow drop to spread. Dry the film in an oven at $45^{\circ} \mathrm{C}$. and fix in absolute alcohol.

2. After the alcohol evaporates, flood the mount with $(a)$ and allow to stain for 10 minutes.

3. If the stain is not deep enough, wash off this alcohol Erythrosin and stain with $(b)$ for 10 minutes.

\section{Exercise 19}

Cultural Characteristics of Root Nodule Bacteria

Select three cultures from the Brom thymol blue slope cultures of Exercise 18, and make subcultures on the various kinds of culture media given below.

(a) Inoculate into litmus milk (Medium 90).

(b) Inoculate into bean extract in shallow layers (Medium 82).

(c) Inoculate on potato slopes (Medium 91).

(d) Inoculate on slopes of xylose, glucose, and sucrose-nitratemineral salts agar to which Brom thymol blue has been added (Medium 78).

After 1,2 , and 3 weeks, at $28^{\circ} \mathrm{C}$., record growth and reaction changes. In the milk tubes, note the effect on reaction and serum zone formation. In the bean extract, note gum production. After 4 to 5 weeks at $28^{\circ} \mathrm{C}$., test for gum. Add 10 cubic centimeters of alcohol ( 95 per cent) or 5 cubic centimeters of acetone to 2.5-cubic centimeter portions of the bean extract culture. Note the thickness of the layer of gum on top of the liquid.

On potato, note growth and pigment formation. In the case of Brom thymol blue agar, note the changes in reaction. Alfalfa bacteria produce a strong acid reaction with all of the carbohydrates listed. Clover bacteria produce a strong acid reaction from glucose, little or no acid from sucrose and xylose. Pea 
bacteria produce a strong acid reaction from glucose, medium acid from sucrose and little or no acid from xylose. Soybean and cowpea bacteria produce a strong alkaline reaction in these culture media.

Prepare the following stain:

Barlow Stain for Root Nodule Bacteria

Glucose......................... $50.0 \mathrm{gm}$.

Glycerol....................... 50.0 cc.

Distilled water................... $50.0 \mathrm{cc}$.

Gentian violet................... $3.0 \mathrm{gm}$.

Dissolve the glucose in the glycerol-water solution by heating and then add the Gentian violet. Bring this mixture to a boil and allow to cool.

Negative Stain.-Place a loopful of the gum from an agar slant culture on a clean slide and rapidly whip out into long thin streaks. Dry in the air.

Flood with the Barlow stain. let stand for 30 seconds to 1 minute and wash off in running water. Blot off the excess water and dry quickly with gentle heat.

Positive Stain.-Prepare the slide as above.

Flood the slide with water and run the stain into this water at one end of the slide. As soon as the stain has diffused through the water, wash in running water and dry quickly.

\section{Exercise 20}

The Formation of Root Nodules in Agar and Sand Cultures

Wash thoroughly the seed of alfalfa, clover, and similar plants, which are to be grown in agar under aseptic conditions, in water and immerse in mercuric chloride solution (1:500) for 2 to 3 minutes. To secure the best results, treat the seeds with

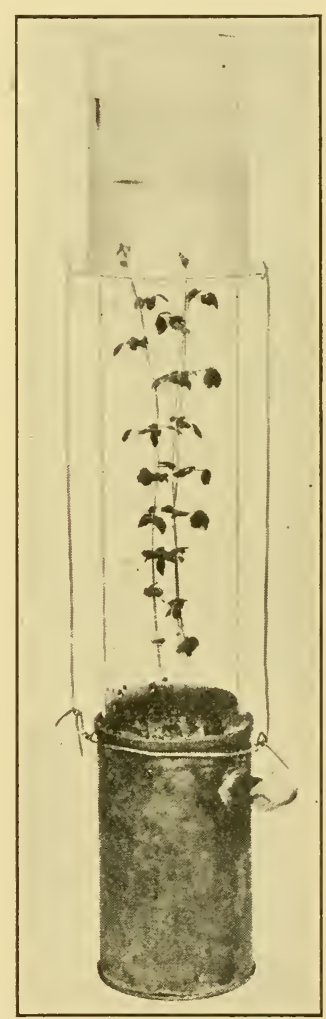

FIG. 7.-Growing plants free of bacteria. A Pyrex glass cylinder 4 inches in diameter and 24 inches tall covered with a beaker. 
mercuric chloride in a partial vacuum. Rinse in sterile water.

In the case of peas, cowpeas, soybeans, etc., which are to be grown in pots of sterilized sand, the seed may be dipped in hot water $\left(65^{\circ} \mathrm{C}\right.$.) for 4 minutes to kill the nodule bacteria. Spread out and dry quickly in an atmosphere free from dust.

Place three to five seeds each of alfalfa or red clover into a large tube containing agar Medium 106.

Plant the peas, soybeans, and related plants, four or five seeds, in half-gallon pots of sand which has been sterilized 4 hours in an autoclave at about 110 to $115^{\circ} \mathrm{C}$. Cover the seed with about 1 inch of sand and add sterile distilled water.

To inoculate, prepare a water suspension of a young culture of the desired organism and from this take 1 cubic centimeter for each tube or pot.

\section{Peas or Soybeans (Pots)}

(a) 1 and 2 uninoculated.

(b) 3 and 4 inoculated with known culture.

(c) 5 and 6 inoculated with an unknown culture.

(d) 7 and 8 inoculated with an unknown culture.
Alfalfa or Clover (Tubes)

1,2 , and 3 , uninoculated.

4,5 , and 6 , inoculated with known culture.

7,8 , and 9 inoculated with an unknown culture.

10 , 11, and 12, inoculated with an unknown culture.

Under favorable conditions, nodules will begin to form on the clover and peas in 10 to 15 days. With alfalfa and soybeans it requires about 21 to 28 days.

Keep cultures in a greenhouse, free from dirt and dust.

Plants in open pots should be watered from time to time with sterile distilled water. About once a week, add about 30 to 40 cubic centimeters of the nitrogen-free modified Crone's solution.

After 4 to 6 weeks examine for nodules; note the number, size, shape, and location.

\section{Exercise 21}

Artificial Cultures for the Inoculation of Legumes

Prepare two 6-ounce Signet bottles of mannitol agar (Medium 77) about 30 cubic centimeters of agar in each. After steriliza- 
tion allow the bottles with the melted medium to cool in a sloped position. When the agar has hardened the bottles are ready for inoculation with the proper bacteria.

Select young cultures of root-nodule bacteria of alfalfa, or clover and cowpea, or soybean from Exercise 13. Inoculate the surface of the agar with three long streaks. Use a large loop which has been bent at right angles.

Incubate the cultures at $28^{\circ} \mathrm{C}$. or room temperature, for 4 to 10 days. Examine the cultures microscopically (Barlow stain) and pack for shipping.

\section{Exercise 22}

\section{The Structure of Root Nodules}

A nodule consists mainly of a mass of large, thin-walled nucleated cells often completely filled with bacteria, i.e., bacteroidal tissue. The action of the bacteria on the plant cells as well as the infection threads may be seen from free hand sections or better from paraffin embedded sections cut about 3 to 5 microns thick.

A. Free-hand Sections.-Cut a cross-section through a young pea nodule and root.

Mount in a drop of water and examine.

To secure a clear section, immerse it for 2 to 5 minutes in a dilute sodium hypochlorite solution and stain with safranin.

$B$. Embedded Sections.--Select young nodules from the desired plant grown in quartz sand or on filter-paper pads.

Fix by immersing for 24 hours in a formol-alcohol-acetic acid mixture.

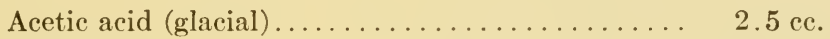

Formalin ...................... $6.5 \mathrm{cc.}$

Alcohol (50 per cent) ................ 100.0 cc.

Transfer to 70 per cent alcohol and change the liquid until there is no odor of acetic acid.

Dehydrate in 80,90 , and 100 per cent alcohol, clear in chloroform, embed in paraffin, and cut microtome sections 3 to 5 microns thick. In order to stain the bacteria and the infection threads use method $A$ or $B$. 
Method A. Flemming's Triple Stain.-For general cytology of the nodule. Vascular system, bacteroid area, shape and position of infection threads, starch grains.

Remove paraffin from the sections in xylol 1 minute; rinse in 95 per cent alcohol 1 minute.

Stain 2 minutes in safranin (saturated solution in equal parts of 95 per cent alcohol and anilin water). Rinse in water.

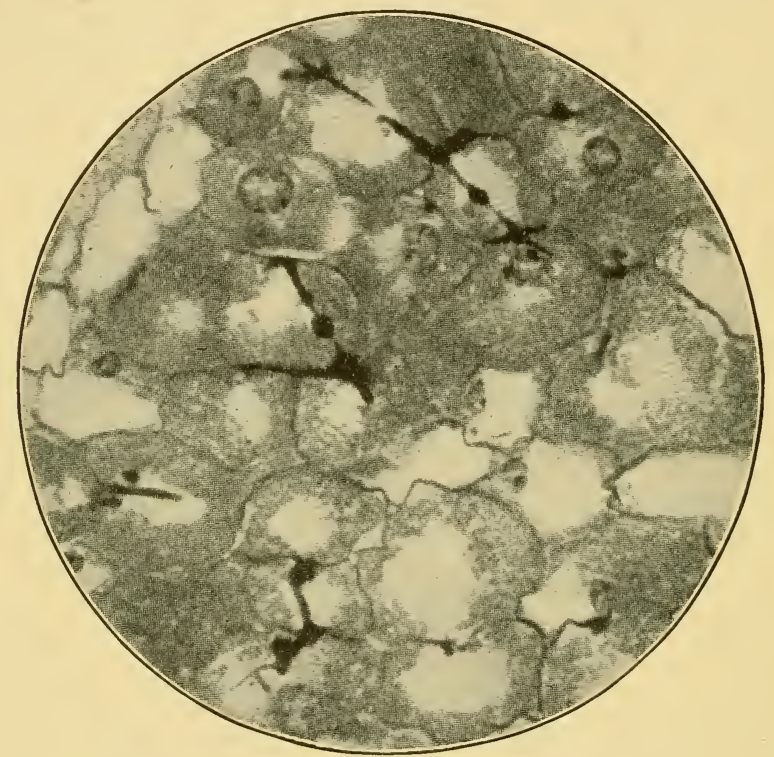

FIG. 8.-Cross-section of alfalfa nodule showing infection threads. Flemming's triple stain.

Stain 3 minutes in crystal violet (saturated aqueous solution). Rinse in water.

Treat with Orange $G$ (saturated aqueous solution) from a medicine dropper. Time should be as short as possible. Rinse with absolute alcohol. Destain with clove oil until the desired differentiation of infection threads and bacteroid tissue is reached; observe under microscope. Rinse quickly in absolute alcohol.

Clear in xylol 5 to 10 minutes.

Mount in Canada balsam.

Method B. Heidenhain's Haematoxylin.-For bacteria within infection threads, internal structure of bacteroids. 
Remove paraffin from the sections in xylol 1 minute; rinse in 95 per cent alcohol 1 minute.

Immerse in iron alum mordant (2 per cent aqueous solution) 4 to 24 hours. Over night is convenient. Rinse in water.

Stain in haematoxylin ${ }^{1} 1$ to 6 hours.

Destain in the mordant until desired differentiation is reached; observe under microscope.

Wash in running water 20 minutes to remove all iron alum and thus prevent fading.

Counterstain in Licht grün (saturated solution in 95 per cent alcohol).

Dehydrate in absolute alcohol, clear in xylol, and mount in balsam.

\section{Exercise 23}

E ffect of Root Nodule Bacteria on the Growth and the Nitrogen Content of Alfalfa

Prepare eight 1/2-gallon jars of clean sand.

Plant to peas as follows:

(a) 1, 2, 3, 4, sand uninoculated.

(b) 5, 6, 7, and 8, sand inoculated.

One week after seeds begin to germinate add 100 cubic centi-

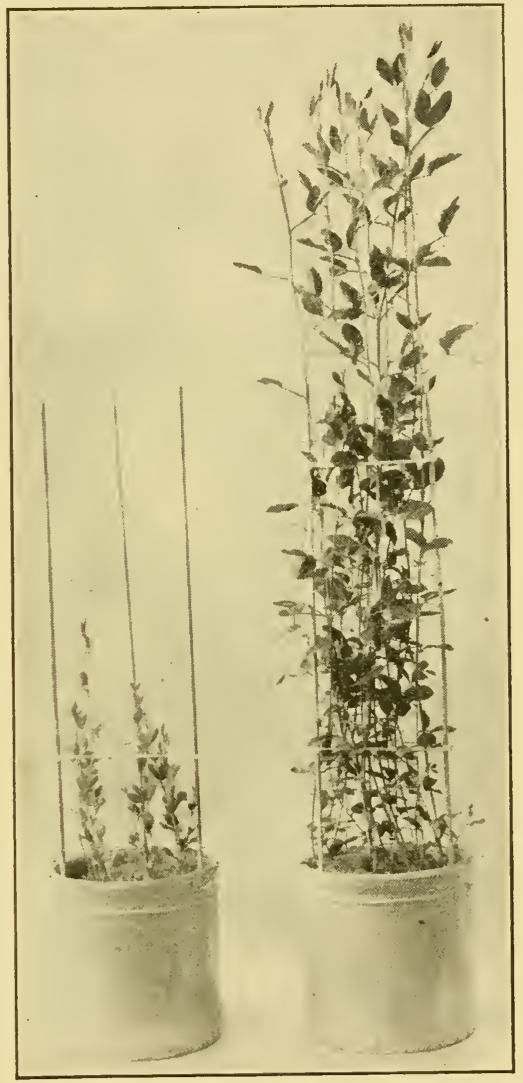

FIG. 9.-Effect of bacteria on growth of sweet peas. Jar on left not inoculated. Jar on right inoculated. meters per jar of plant food minus nitrogen (Crone's Medium 106). This nutrient solution should be added at intervals of every 2 weeks or whenever needed.

${ }^{1}$ Heidenhain's Haematoxylin. Dissolve 5 grams of haematoxylin crystals in 400 cubic centimeters of absolute alcohol using heat if necessary. Add 600 cubic centimeters of distilled water and allow the solution to ripen a month or more. 
After 6 to 8 weeks examine for nodules.

When mature, remove and analyze the tissue for total nitrogen.

\section{Exercise 24}

Direct Method for Demonstrating the Occurrence of Azotobacter IN Soll

A. Macroscopic Method (Winogradsky). ${ }^{1}$ - To 100 grams of freshly sieved soil, add 5 grams of pulverized starch. Mix the starch thoroughly with the soil.

Transfer the starch-soil mixture to a shallow dish and add water in sufficient amount to make a thick paste of the soil. Avoid too much water.

Divide the soil paste between two Petri dishes. Press the soil well into the Petri dishes, and smooth off the surface with a wet glass slide. Make the top as smooth and even as possible.

Incubate the plates at $28^{\circ} \mathrm{C}$. for 48 hours. If Azotobacter is present in the soil, small limpid colonies will be observed on the surface of the plate. Stain these colonies of organisms for 2 to 3 minutes with thionin or erythrosin. Pure cultures may be obtained from these colonies (see Exercises 25 and 26).

B. Microscopic Method.-Thoroughly mix 0.5 gram of mannitol with 50 grams of soil. Place the mixture in a Petri dish, and moisten the soil with water.

Incubate the plate at $28^{\circ} \mathrm{C}$. for 48 hours.

Make an erythrosin or thionin stain of the soil. Azotobacter cells will frequently be observed.

Anærobic nitrogen fixing organisms ( $C l$. pasteurianum) can be cultivated by adding 0.5 gram of glucose to 50 grams of soil and mixing thoroughly. Divide the soil-glucose mixture between three large test tubes and saturate the soil with water.

Incubate the tubes at $28^{\circ} \mathrm{C}$. and examine microscopically after 48 hours. Examine portions of the soil taken from different depths in the tube.

\section{Exercise 25}

Isolation of Azotobacter from Various Solls

Prepare four small Erlenmeyer flasks of mannitol liquid medium (Medium 77), about 20 cubic centimeters in each. Avoid deep layers.

${ }^{1}$ Winogradsky, S., Ann. Inst. Past., 40 : 455 (1926). 
Inoculate with 1 or 2 grams of soil and incubate at $28^{\circ} \mathrm{C}$. and note changes occurring in cultures, film formation, and color of film.

After 2 days, examine the films in hanging-drop or wet mount and note the predominating type of organism. Also examine some of the surface film in a drop of water mixed with a drop of Meissner's or Gram's iodin solution. Prepare stained mounts

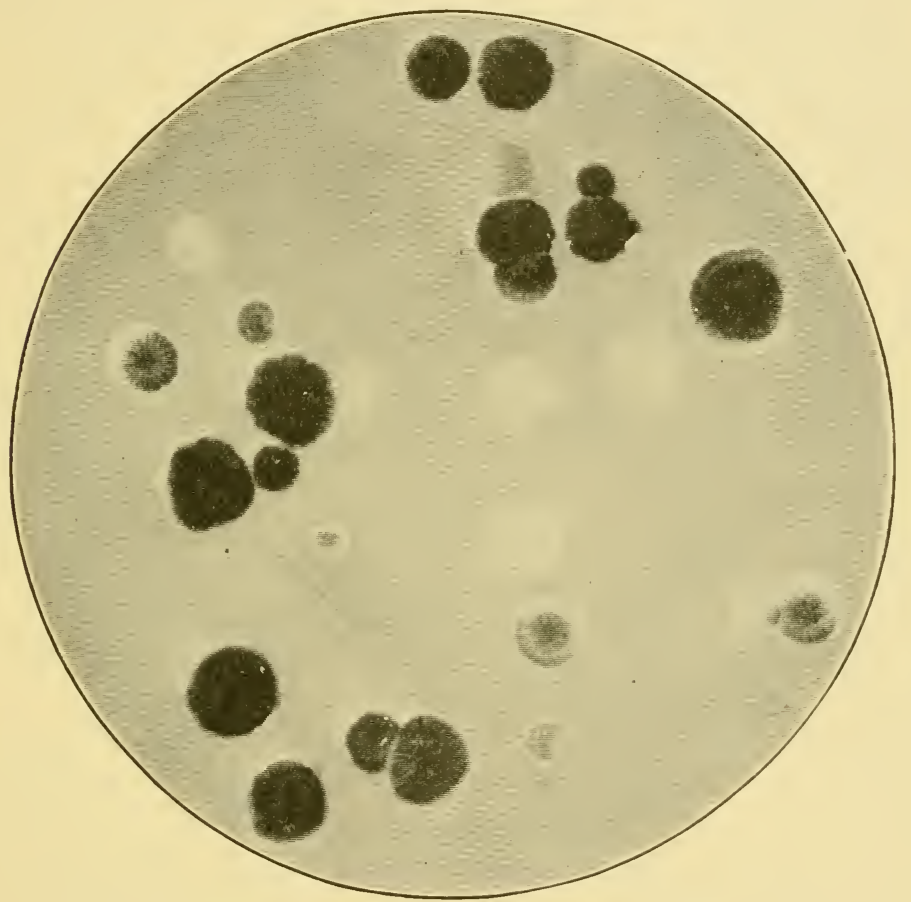

Fig. 10.-Colonies of Azotobacter on mannitol agar, natural size.

with thionin and carbol erythrosin. The Erythrosin stain is especially good for young cultures.

Dilute two loops of surface film in a 100 -cubic centimeter sterile water blank containing 50 grams of clean sand.

Shake vigorously, and transfer 1 cubic centimeter to a second 100-cubic centimeter blank, and so on to a third.

From the second and third dilution pour plates, using 1 cubic centimeter for each. Because of the ærobic nature of Azotobacter 
dilutions on the surface of the agar offer an easy and rapid method of isolation. Sometimes it is difficult to separate Azotobacter from a small organism known as Bacterium radiobacter.

After 4 to 6 days examine plates. The Azotobacter colonies are raised, convex, smooth, white, semi-opaque, moist, viscid, often 4 to 8 millimeters in diameter. Make transfers to mannitol agar slants. Stain with carbolated rose bengal or erythrosin.

Noте.-Instead of the enrichment liquid culture described above, isolations may be made directly from the colonies on soil, Exercise 24 .

\section{Exercise 26}

Use of Silica Gel Plate for Isolation of Specific Bacteria

Silica-gel plates are prepared as described under culture media and dialyzed free from chlorides. A sterile solution containing the necessary mineral salts and the specific substrate is placed upon the surface of the gel. The uncovered plates are then placed in a warm place (at $60^{\circ} \mathrm{C}$.) to allow the evaporation of excess liquid, care being taken that medium does not become too dry.

The silica gel is then inoculated with small particles of soil.

After a few days incubation, growth will take place around each particle of soil. The nature of the organism developing will depend upon the nature of the medium added to the gel.

A mannitol medium free from combined nitrogen will allow the development of Azotobacter under ærobic and of $\mathrm{Cl}$. pasteurianum under anærobic conditions.

A medium containing cellulose and an inorganic source of nitrogen will allow the development of Spirochæta and other cellulose decomposing bacteria.

When the colonies have developed sufficiently, they can be transferred to specific nutrient media.

\section{Exercise 27}

Nitrogen Fixation by Pure Cultures of Azotobacter

Prepare four 1-liter Erlenmeyer flasks with 100 cubic centimeters each of mannitol agar (Medium 77). In place of the 
flasks large pans or moist chambers may be used. The object is to use a vessel that will give a large surface exposure.

After sterilization, inoculate the agar films with a pure culture of Azotobacter. This may be accomplished by using 1-cubic centimeter transfers from a suspension in sterile water.

Immediately after inoculation remove half of the cultures for control analysis. These may be treated with sulphuric acid or sterilized.

A few days after inoculation, add 5 cubic centimeters of sterile water to each culture.

Incubate the cultures in such a position that only a portion of the surface will be covered with water, and from day to day rotate. In this way it is possible to get an even film over the entire surface.

About $28^{\circ} \mathrm{C}$. is a favorable temperature tures. (Krzemieniewshi.) for growth.

After 21 days, analyze all of the cultures for total nitrogen.

\section{Exercise 28}

Effect of Variation in Carbohydrate on the Growth of Azotobacter

Prepare six tubes of culture Medium 77, without mannitol.

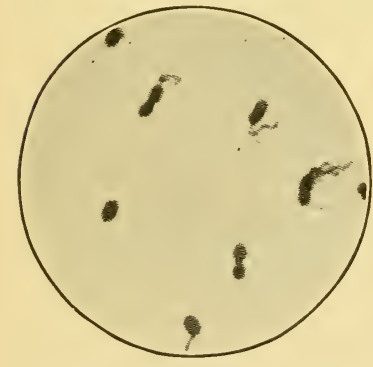

FIG. 12.-Azotobacter agile showing flagella, $\times 660$. (Beijerinck.)

(a) 1 and 2 , control (without mannitol).

(b) 3 and 4 , add 1 per cent of mannitol.

(c) 5 and 6 , add 1 per cent of lactose.

Inoculate all cultures from a water suspension of a young culture of Azotobacter. Incubate tubes 1,3 , and 5 in the open and tubes 2,4 , and 6 in the anærobic jar. Examine every 2 or 3 days for a period of 14 days.

Record the growth and pigment formation of Azotobacter on the various culture media. If the tubes kept under anærobic conditions fail to show a brown to black pigment after 2 weeks, open the jar, incubate again and note change in the color. 


\section{Exercise 29}

Anerobic Nitrogen Fixation (Clostrididm pasteuriandm and Related Organisms)

Prepare four small flasks (or 6-ounce Signet bottles) with 150 cubic centimeters of Winogradsky's solution (Medium 11). Arrange to have the liquid high in the necks of the flasks (or bottles).

As soon as possible after sterilization inoculate all of the flasks with a pasteurized soil extract. Heat 50 grams of soil with 200 cubic centimeters of water for 15 minutes at $80^{\circ} \mathrm{C}$.

Allow the coarse particles to settle and pipette 5-cubic centimeter portions into each of the four flasks.

Arrange as follows:

(a) 1 and 2, controls (sterilize immediately, or add 5 cubic centimeters of sulphuric acid. In order to avoid too rapid evolution of carbon dioxide, the sulphuric acid should be added slowly).

(b) 3 and 4, cultures of anærobic bacteria. Incubate all flasks at $28^{\circ} \mathrm{C}$.

One week after incubation examine under the microscope a drop taken from the lower layers of the liquid. This may be done by inserting a pipette. Make a wet mount using Meissner's solution. What forms are seen? Note the color. Make a permanent spore stain, Dorner method.

After 21 days transfer the entire contents to a Kjeldahl flask and analyze for total nitrogen.

\section{Exercise 30}

Isolation of Anferobic Nitrogen-fixing Organisms (Clostridium pasteuriandm and Related Forms)

From the impure cultures of Exercise 26 or 29 make isolation plates on agar medium (Medium 12).

From the bottom of an actively fermenting culture take 1 or 2 drops and spread on the surface of the glucose peptone agar in Petri dish. Dilute by spreading over the surface of at least three plates. To secure the best results use Petri dishes with porous covers. 
Incubate the plates under anærobic conditions (potato jar) and pick colonies into Winogradsky's liquid medium or corn mash.

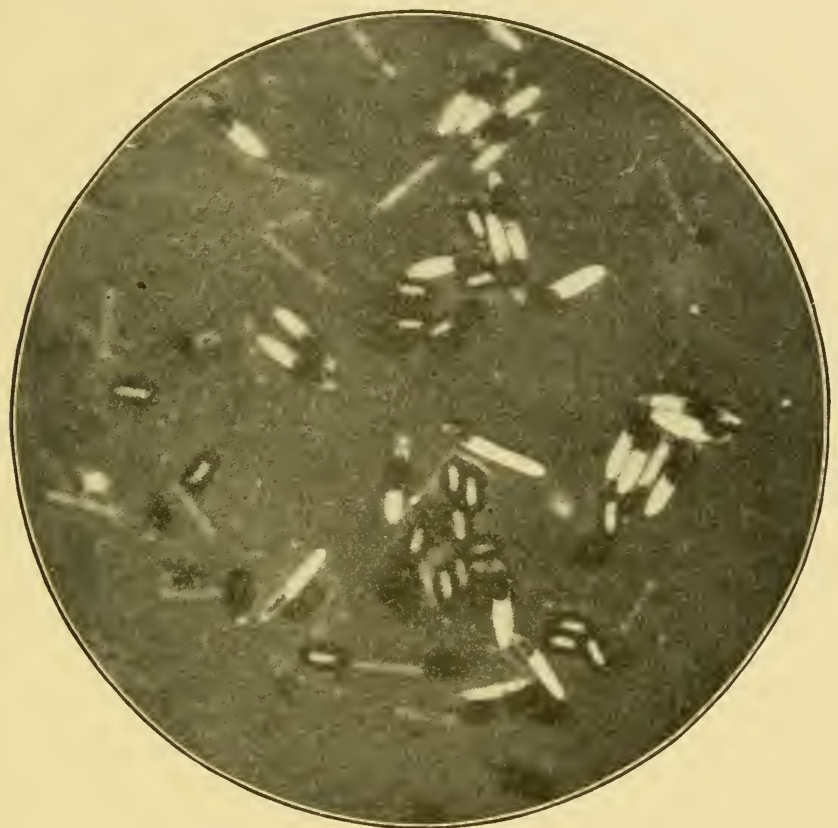

FIG. 13.-Dorner spore stain of anaerobic nitrogen-fixing bacteria.

\section{Exercise 31}

\section{Nitrogen-fixing Capacity of Soll ${ }^{1}$}

Large Petri dishes (20 centimeters in diameter) are filled with the selective silica gel medium (see Exercise 26) containing 2 grams of mannitol.

The surface of the gel in the plate is inoculated with 1 gram of soil (on dry basis).

Plates are incubated at $30^{\circ} \mathrm{C}$. for 7 days.

The gel in the plates is now dried and contents transferred to Kjeldahl flasks and total nitrogen determined.

1 Winogradsky, S., and J. Ziemiecka, Ann. Inst. Past., 42: 35, 1928. 


\section{Exercise 32}

Influence of Nitrate on the Fixation of Nitrogen

Prepare eight large silica plates containing 2 grams of mannitol and medium for fixation of nitrogen. Arrange as follows:

(a) 1 and $2 \ldots \ldots \ldots \ldots$ no nitrate.

(b) 3 and $4 \ldots \ldots \ldots \ldots \ldots, 1.0 \mathrm{mgm}$. of nitrate nitrogen.

(c) 5 and $6 \ldots \ldots \ldots \ldots \ldots, 5.0 \mathrm{mgm}$. of nitrate nitrogen.

(d) 7 and $8 \ldots \ldots \ldots \ldots \ldots 25.0 \mathrm{mgm}$. of nitrate nitrogen.

Inoculate each with 1 gram of good garden soil. Incubate for 7 days at $30^{\circ} \mathrm{C}$.

Dry gel and determine total nitrogen.

Tabulate results.

\section{Exercise 33}

Effect of a Soluble Carbohydrate on Nitrogen Assimilation

Weigh out two 400- to 500-gram portions of field or garden soil in deep soup plates or shallow earthenware jars. The soil should be thoroughly mixed and sieved.

(a) Control-untreated.

(b) Add 2 per cent of mannitol, glucose, sucrose, lactose, or other carbohydrates.

Mix the carbohydrate thoroughly with the soil by means of a spatula and then add tap water until the moisture content of the soil is about two-thirds saturation. Do not attempt to mix soil and carbohydrate immediately after the water is added. At intervals of about 2 days add more water, sufficient to replace the loss by evaporation and incubate at $28^{\circ} \mathrm{C}$. for from 14 to 21 days. At the end of this time the carbohydrate should be entirely destroyed.

Prepare the soil for analysis. When dry, pass it through a 20mesh sieve, mix thoroughly, and draw a small sample for analysis; about 100 to 150 grams is enough. This smaller sample should be pounded in a mortar until the entire mass passes through a 100-mesh sieve. Weigh out from three to six portions of 10 grams from each jar into 800-cubic centimeter Kjeldahl flasks and analyze according to the Kjeldahl method not to include nitrates (p. 65). 
Make moisture determinations on the soil at the time samples are taken for nitrogen analysis. Tabulate results.

\section{DENITRIFYING BAOTERIA}

\section{Exercise 34}

\section{Isolation of Denitrifying Bacteria}

Fill three test tubes about two-thirds full of asparagin nitrate solution (Medium 55).

Inoculate as follows:

(a) Control-no inoculation.

(b) Inoculate with approximately 0.1 gram of garden soil.

(c) Inoculate with approximately 0.1 gram of fresh manure. Incubate at $28^{\circ} \mathrm{C}$. until all nitrates have disappeared. The destruction of nitrates is generally indicated by foaming.

At regular intervals, daily if possible, make qualitative tests (spot plate) for the presence of nitrates, nitrites, and ammonia.

As soon as the nitrates are destroyed, transfer a loopful of the old culture to a new tube of asparagin nitrate solution. This may be repeated several times, although a pure culture is readily isolated from the second transfer.

Follow the same method of isolation as given in the previous exercises. It is well to make a series of not less than four dilutions. Pour plates of asparagin nitrate agar and incubate until there is a good growth.

Now pick off several isolated colonies, making transfers into tubes of asparagin nitrate solution.

From the pure culture showing the most vigorous destruction of nitrates make a transfer to the agar medium. Preserve this pure culture for later study.

\section{Exercise 35}

\section{Denitrification by Pure Cultures of Bacteria}

Prepare four bottles, 125 cubic centimeters each, of asparagin nitrate solution (Medium 55). Because of the total nitrogen analyses to be made at the end of this experiment it is well to prepare the medium with great care. Exact amounts of the 
nitrate and asparagin salt, previously analyzed for total nitrogen should be used.

(a) Control-not inoculated.

(b) Pure culture of unknown organism capable of bringing about denitrification.

(c) Pure culture of unknown organism capable of bringing about denitrification.

(d) B. pyocyaneus, B. fluorescens liquefaciens, or B. hartlebii.

After 2 to 3 days incubation at $28^{\circ} \mathrm{C}$. make qualitative tests of each culture for ammonia, nitrites, and nitrates. After 7 to 10 days incubation make quantitative determinations of nitrates and total nitrogen.

Use the modified Kjeldahl method to include nitrates. For total nitrogen analysis take portions of 50 cubic centimeters each of the cultures.

Nitrates.-Take 10-cubic centimeter portions of the control, dilute with 100 cubic centimeters of distilled water, and of this evaporate 10 -cubic centimeter portions to dryness.

In the case of the inoculated cultures with nitrates present, take 2 samples and proceed as follows: (a) Evaporate 10 cubic centimeters to dryness, and $(b)$ dilute 10 cubic centimeters to 100 cubic centimeters and evaporate 10 cubic centimeters of this to dryness.

\section{Exercise 36}

Denitrification in Soll

Prepare eight 100-gram samples of field soil in tumblers. Add to each sample of soil 60 milligrams of nitrogen in the form of potassium nitrate.

Treat the series as follows:

(a) 1 and 2, control untreated.

(b) 3 and 4 , add 2.5 grams of glucose.

(c) 5 and 6 , control untreated.

(d) 7 and 8, add 2.5 grams of glucose.

Mix these materials thoroughly by means of a spatula.

To soil portions 1 to 4 , add sterile water to bring the moisture content to about one-half saturation.

To soil portions 5 to 8 add sterile water to bring moisture up to total saturation. 
Incubate for two weeks at $28^{\circ} \mathrm{C}$.

At the end of this time remove a sample for nitrate determination and dry the remainder for total nitrogen analysis. Use the modified Kjeldahl method to include nitrates (see p. 67).

From these results calculate the percentage of the nitrogen denitrified, and note the effect of excessive moisture and excessive organic matter on the loss of nitrogen.

Tabulate results.

\section{NITRIFICATION}

\section{Exercise 37}

Nitrification in Impure Cultures

\section{A. Nitrite Formation (Qualitative)}

(a) Prepare five 150-cubic centimeter Erlenmeyer flasks with 20-cubic centimeter portions each of "ammonia" solution (Medium 48).

(b) Inoculate two of the flasks and incubate at $28^{\circ} \mathrm{C}$.

1. Add approximately 0.1 gram of field soil.

2. Add approximately 0.1 gram of garden soil.

(c) At regular intervals of 7 to 10 days remove, with a sterilized platinum needle or pipette, 1 drop of the solution from each flask and test as follows:

1. Nitrites-Trommsdorf's reagent.

Place 3 drops of Trommsdorf's reagent in a depression of a spot plate. Add 1 drop of dilute sulphuric acid (1:3). Remove a loopful of the solution to be tested and touch to surface of reagent. A blue color indicates the presence of nitrites.

2. Ammonia-Nessler's reagent.

Place in a depression on a spot plate 1 drop of Nessler's solution. Remove a loopful of the solution to be tested and touch to surface of reagent. Do not stir. A yellow-brown color indicates ammonia.

(d) As soon as the culture shows the presence of nitrites and absence of ammonia, make subinoculations into a sterile flask of the same medium. If it is desired to study the nitrite bacteria in enrichment cultures, repeated subinoculations may be made.

B. Nitrate Formation (Qualitative).-Prepare five 150-cubic centimeter Erlenmeyer flasks with 20-cubic centimeter portions each of nitrite solution (Medium 51). 
Inoculate two of the flasks and incubate at $28^{\circ} \mathrm{C}$.

1. Add approximately 0.1 gram of field soil.

2. Add approximately 0.1 gram of garden soil.

At regular intervals of 7 to 10 days remove, with a sterilized platinum needle, 1 drop of the solution from each flask and test as follows:

1. Absence of nitrites-Trommsdorf's reagent.

2. Presence of nitrates-Diphenylamine reagent.

Place in a depression on a spot plate a drop of concentrated sulphuric acid plus diphenylamine. Touch with a drop of the solution to be tested. A deep-blue color indicates nitrates. This test cannot be made in the presence of nitrites, chloric, and selenic acids, ferric chloride, and many other oxidizing agents. If the test for nitrites (Trommsdorf) is positive do not make this test.

As soon as the culture shows the presence of nitrates and absence of nitrites, make loop subinoculations into a sterile flask of the same medium. If it is desirable to study the nitrate bacteria in enrichment cultures, repeated subinoculations may be made.

\section{Exercise 38}

Nitrification in Liquid Cultures (Quantitative)

Prepare two flasks (750-cubic centimeter capacity) with 100 cubic centimeters each of Medium 52.

Inoculate each flask with 1 cubic centimeter of enrichment culture-ammonia oxidizing-and 1 cubic centimeter of nitrite oxidizing culture.

Incubate the flasks at $28^{\circ} \mathrm{C}$.

Once a week test the solution for the oxidation of ammonia and nitrite. If this process is complete, add 1 cubic centimeter of a 10 per cent solution of ammonium sulphate. Repeat until the oxidation of the ammonium sulphate ceases. If necessary, add a small amount of magnesium carbonate to the culture.

After the cultures cease to oxidize, make qualitative tests for ammonia, nitrite, and nitrate. If nitrates are present, make quantitative analyses by the phenoldisulphonic method as given on page 63 . 


\section{Exercise 39}

\section{Isolation of Nitrifying Organisms}

Prepare eight tubes of acid sodium-potassium silicate.

Dilute the second enrichment cultures of the nitrite and nitrate organisms until 1 cubic centimeter represents $1: 1,000$, $1: 10,000,1: 100,000$, and $1: 1,000,000$ of the original culture.

Pour the acid silicate into a sterile Petri dish with the culture dilutions; add the nutrient salts and enough sodium carbonate to harden the silicate.

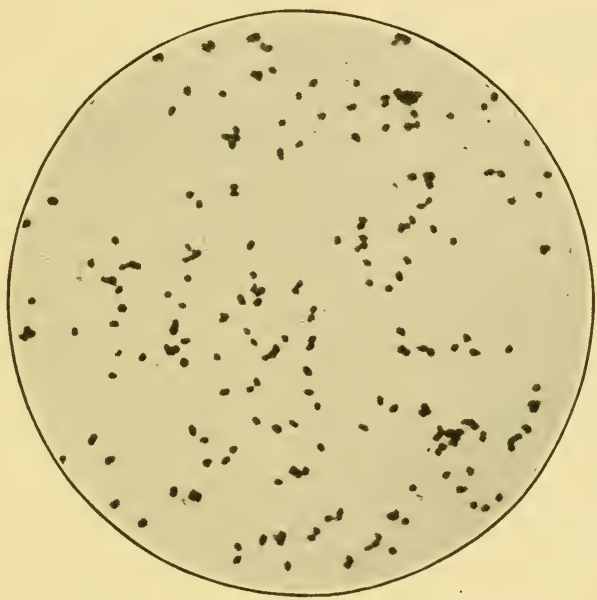

FIG. 14.-Nitrobacter in liquid culture.

When hard, invert the plates and incubate under a moist bell jar for 3 to 6 weeks. The cultures may also be streaked on the surface of silica gel.

Examine at weekly intervals, using the low-power objective. As soon as small colonies appear, make transfers to sterile nitrite or nitrate solution.

The nitrifying organisms may be also grown on washed agar.

\section{Exercise 40}

Nitrification of Various Substances

Prepare two portions of soil, 500 to 700 grams each, in small jars. Mix and sieve the soil well before using.

(a) Control-no treatment. 
(b) Add 30 milligrams of nitrogen per 100 grams of soil from $\left(\mathrm{NH}_{4}\right)_{2} \mathrm{SO}_{4}$, blood meal, casein, or peptone.

Mix these substances thoroughly with the soil, add sterile water to give one-half to two-thirds saturation, record weight and incubate at $28^{\circ} \mathrm{C}$.

Each week, weigh and restore loss of water by evaporation.

After 10 and 20 days determine the nitrate nitrogen.

Express the results as milligrams of nitrate nitrogen in 100 grams of soil; also as percentages of the original substance nitrified.

Tabulate results.

\section{UREA AND PROTEIN DECOMPOSITION}

\section{Exercise 41}

\section{Decomposition of Urea}

Prepare three Erlenmeyer flasks or bottles, 200-cubic centimeter capacity, with 50 cubic centimeters each of urea solution (Medium 45).

After sterilizing, arrange as follows:

(a) Control-not inoculated.

(b) Inoculate with 1 gram of soil.

(c) Inoculate with 1 gram of fresh manure.

It is not necessary to weigh accurately the soil or manure. Incubate the cultures at $28^{\circ} \mathrm{C}$. and after 2 days remove from each flask 5-cubic centimeter portions of the solution, with a sterile pipette, to a small Erlenmeyer flask. Add about 50 cubic centimeters of distilled water to the urea solution and a few drops of methyl red. Determine the ammonia production by titrating with $N / 14$ acid.

From the results of the titrations, calculate the amount of ammonia nitrogen in 100 cubic centimeters of the different urea solutions. In order to find the amount of ammonia formed by bacterial action, subtract the untreated from the treated series.

Determine the percentage of urea nitrogen transformed into ammonia nitrogen.

Similar samples may be drawn after 3 or 4 days and the amount of ammonia determined. Tabulate the results. 


\section{Exercise 42}

Isolation of Specific Urea-decomposing Organisms

Pour isolation plates of several dilutions of the enrichment cultures of Exercise 41. Use urea agar or gelatin Medium 47.

Incubate the plates at $28^{\circ} \mathrm{C}$.

Examine the plates every 48 hours for a period of 10 days. The urea organisms are often characterized by a distinct halo around the colonies. Under the low power of the microscope the halo is composed of crystals.

Make transfers to tubes of urea solution Medium 44 or 45 and incubate for two days.

Now test the ammonia-producing power of the pure cultures by inserting sterilized strips of Nessler's paper or tumeric paper in the upper part of the tube.

Prepare a stained mount of these organisms.

\section{Exercise 43}

Ammonia Production from Various Substances in Soll

Prepare 500-gram portions of soil in small jars. The soil should be mixed thoroughly.

1. Control-no treatment.

2. Soil plus 0.5 per cent of blood meal, casein, peptone, alfalfa meal, soybean meal, or similar substances.

After these substances are mixed with the soil bring the moisture content of the soil to two-thirds saturation. In order to secure the proper moisture content it is necessary to take into account the water-holding capacity of the added substances.

Incubate at room temperature and, after 2, 5, and 7 days, determine the ammonia nitrogen.

Ammonia may be estimated in a number of ways. The aeration method is usually considered the most accurate although good results may be obtained by the leaching of the soil with a strong chloride solution and distilling with magnesium oxide.

Determination of Ammonia Nitrogen. ${ }^{1}-$ Weigh out 50 grams of soil in a 750-cubic centimeter Pyrex Erlenmeyer flask. Add 500 cubic centimeters of a 10 per cent $\mathrm{KCl}$ solution (in case of neutral or alkaline soils use a 20 per cent $\mathrm{KCl}$ solution); shake for

${ }^{1}$ Harper, H. J., Soil Sci., 18: 409, 1924. 
30 minutes in a mechanical shaker; allow to settle 10 minutes and filter on a large folded filter. Transfer 400 cubic centimeters of filtrate to a Kjeldahl flask, add a small piece of paraffin to prevent foaming and a little 20-mesh limestone to prevent bumping. Distill with 1 gram of $\mathrm{MgO}$.

\section{Exercise 44}

Decomposition of an Amino Acid and a Protein by Bac. oereus and BACT. FLUORESCENS

Prepare 1 liter of a mineral salt solution.

Weigh out 3 grams of $\mathrm{K}_{2} \mathrm{HPO}_{4}, 0.2$ gram KCl, 0.2 gram $\mathrm{MgSO}_{4}$, 0.2 gram $\mathrm{NaCl}, 0.1$ gram $\mathrm{CaSO}_{4}$ and 0.01 gram $\mathrm{FeSO}_{4}$, in 1,000.0 cubic centimeters of water.

To 500 cubic centimeters add 5 grams of glycocoll and mark solution "Glycocoll medium;" the other 500 cubic centimeters is used for the casein solution.

Weigh out into a beaker 5 grams of casein, purified (Hammersten). Add about 50 cubic centimeters of the medium and suspend the casein in it. Then add 4 cubic centimeters of $1 N$. $\mathrm{NaOH}$ solution, warm until casein has dissolved. Filter. Add casein solution to the rest of the salt solution, make up to 500 cubic centimeters and mark it "Casein solution."

Distribute the two solutions in 50-cubic centimeter portions in 250-cubic centimeter Erlenmeyer flasks, plug with cotton, and sterilize.

Inoculate two flasks of each medium with a pure culture of Bacillus cereus and two flasks of each medium with a pure culture of Bacterium fluorescens. Leave 1 flask of each as control. Incubate 14 days.

Examine cultures for growth and determine in each flask the amino-acid-nitrogen, ammonia, and residual casein.

Tabulate results.

\section{SULPHATE-REDUCING AND SULPHUR-OXIDIZING BACTERIA}

\section{Exercise 45}

Reduction of Sulphates by Bacteria

Prepare three small bottles of sulphate medium (Medium 60), and treat as follows:

(a) Control-uninoculated. 
(b) 1 gram of rich garden soil.

(c) 1 cubic centimeter of sewage.

Stopper tightly with paraffined corks and incubate at $28^{\circ} \mathrm{C}$. for 2 or 4 weeks.

At the end of this time remove bottles from incubator and note the change in color and odor.

Hold over the open mouth of the bottle a small piece of filter paper saturated with a solution of lead acetate. A blackening of the paper indicates the presence of hydrogen sulphide.

Remove a few cubic centimeters with a pipette to a test tube or small Erlenmeyer flask and add a few drops of $\mathrm{BaCl}_{2}$ solution.

Compare the amount of white precipitate in the inoculated cultures with that in the uninoculated control.

The amount of hydrogen sulphide may be determined quantitatively by titrating with iodine and sodium thiosulphate.

\section{Exercise 46}

\section{Isolation of Hydrogen Sulphide-Forming Microorganisms}

Prepare five deep tubes of Medium 62.

Make shake cultures, deep tubes, from varying dilutions of the enrichment cultures of Exercise 45 (reduction of sulphates with the formation of $\mathrm{H}_{2} \mathrm{~S}$ ).

After the inoculated tubes have hardened, cover with glycerol agar to a depth of about 2.5 centimeters. Incubate at $28^{\circ} \mathrm{C}$. and note the formation of colonies. After 5 to 10 days these colonies become brown to black in color. Pure cultures may be obtained from these deep colonies by cutting the tubes and transferring the black colonies to fresh tubes of Medium 62 .

GLycerol Agar ${ }^{1}$

Agar, washed................. $20.0 \mathrm{gm}$.

Glycerol $\left(\mathrm{C}_{3} \mathrm{H}_{5}(\mathrm{OH})_{3}\right) \ldots \ldots \ldots \ldots \ldots \ldots \ldots \ldots \ldots$. $500.0 \ldots \ldots . \ldots \ldots$ cc.

Distilled water................... 500.0 cc.

${ }^{1}$ Dissolve the agar in the water by heating in a steamer, add the glycerol and filter. 


\section{Exercise 47}

Crude Cultures of Higher Sulphur Bacteria

Place some mud from ditches or other bodies of water in a large flask or cylinder and cover to a depth of 3 to 6 inches with fresh or salt water.

Add 5 grams of magnesium sulphate and 2 grams of calcium carbonate per liter of water. This furnishes a supply of $\mathrm{H}_{2} \mathrm{~S}$ due to the action of sulphate-reducing bacteria present in the mud.

Inoculate the solution with material that contains the sulphur bacteria, namely pond scum, submerged plant material, organic matter from sulphur springs, etc. $\mathrm{H}_{2} \mathrm{~S}$ may also be used in the form of a gas.

Incubate in the dark for colorless sulphur bacteria, while, for colored forms, the cultures are exposed to transmitted light. Growth may appear on surface of liquid, along walls of container, or on surface of mud.

Concentration of $\mathrm{H}_{2} \mathrm{~S}$, amount of mud added to flasks, purity of water used, amount and nature of inoculum will all influence the type of organism developing. The red forms develop better under higher partial pressures of $\mathrm{H}_{2} \mathrm{~S}$ than the colorless forms.

\section{Exercise 48}

Isolation of Pure Cultures of Higher Sulphur Bacteria 100-cubic centimeter portions of Medium 70 are placed in 250-cubic centimeter Erlenmeyer flasks and sterilized, the ammonium sulphate being sterilized separately in stock solutions, then added to the rest of the medium, after sterilization.

Inoculate flasks from enrichment cultures obtained in previous experiment, using as little foreign material as possible.

The flasks are then placed under jar $(e)$ into which hydrogen sulphide is introduced, as shown in Fig. 1 (p. 30).

The sulphide is generated by the action of $\mathrm{HCl}$ upon $\mathrm{FeS}$ in (a).

Hydrogen, $\mathrm{CO}_{2}$, oxygen, or air may be introduced from compressed gases $(b)$ in regulated amounts controlled by manometer attachment $(f)$. 
Agar media containing $\mathrm{CaCO}_{3}$ may be employed for isolation purposes.

Frequent transfer of the cultures and incubation in $\mathrm{H}_{2} \mathrm{~S}$ atmosphere will finally lead to isolation of pure cultures.

\section{Exercise 49}

Oxidation of Sulphur and the Dissolving of Rock Phosphate

Prepare a mixture of 60 parts good garden soil, 30 parts of finely ground rock phosphate, and 10 parts of powdered sulphur. Place in pots or tumblers.

Add enough water to bring to 60 per cent saturation.

Incubate at $25^{\circ} \mathrm{C}$.

At the end of every week, mix mixture well and add enough water to keep at optimum.

After 2, 7, 21, 42, 70, and 100 days, determine $\mathrm{pH}$ value, amount of water soluble sulphate, and phosphate. Draw curves.

After 2 and 60 days, determine also number of bacteria and fungi by ordinary plate method.

\section{Exercise 50}

Growth and Isolation of Thiobacillus thioparus

Prepare 600 cubic centimeters of Medium 65. Distribute, in 100 cubic centimeter portions, into 250 cubic centimeter Erlenmeyer flasks. Do not sterilize.

Inoculate two flasks with 1-gram portions of garden soil, two with fresh manure. Incubate flasks.

Test every 3 days for disappearance of thiosulphate, using a dilute iodine solution.

The flasks where the thiosulphate has first disappeared are used for inoculation of two flasks with fresh medium.

After the thiosulfate has disappeared in the second lot of flasks, examine culture microscopically.

Note bacteria and granules of precipitated sulphur.

Culture is now plated upon thiosulphate agar.

Incubate.

Isolate from the sulphur-yellow colonies into flasks with sterile liquid medium, in which the nitrogen salt and carbonate have been sterilized separately and mixed aseptically. 


\section{Exercise 51}

Growth of Thiobacillus Thiooxidans in Liquid Medium

Prepare six flasks of medium (Medium 68).

Inoculate two flasks with 1-gram portions of compost from Exercise 49 (100 days old), two flasks with 0.1 gram of same compost. Two flasks are left as controls.

Incubate flasks at $25^{\circ} \mathrm{C}$.

After 7, 14, and 30 days, determine $\mathrm{pH}$ of flasks.

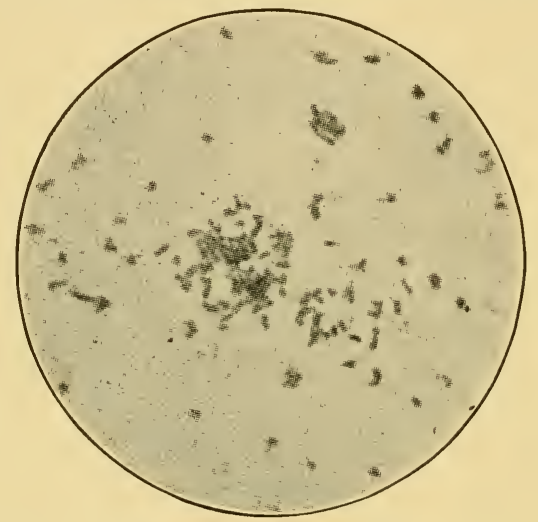

Fig. 15.-Thiobacillus thiooxidans $(\times 1,000)$.

If there is an increase in acidity in the inoculated flasks above the control, determine sulphates in solution in all flasks, and examine culture microscopically.

Repeated transfers of the culture upon fresh sterile medium will result in a highly enriched culture of the organism. Final isolation can be made by the use of the agar plate. ${ }^{1}$

${ }^{1}$ Waksman, S. A., Jour. Bact., 7: 605-608, 1922.

\section{IRON BACTERIA}

\section{Exercise 62}

Iron-PREcipitating Bacteria (Optional)

Shake 20 grams of field soil with 200 cubic centimeters of water. Dilute until 1 cubic centimeter equals $1: 100,000$.

Pour plates of Medium 101 or similar formula.

Incubate the plates for several weeks at $28^{\circ} \mathrm{C}$.

Note the precipitation of iron compounds around certain colonies. 


\section{Exercise 53}

Iron Bacteria from Drinking Water

Clean and sterilize a Berkefeld filter.

Connect the filter to the city water-supply and allow the water to run slowly for 24 to 48 hours.

After the metal cap is removed from the filter, place the filter in a large beaker of iron solution (Medium 76).

Incubate in the ice-box or at about 15 to $20^{\circ} \mathrm{C}$.

At regular 2-day intervals examine the deposit on the sides of the filter.

If bacteria are found, test for iron. Add a few drops of a 5 per cent hydrochloric acid solution and a 4 per cent potassium ferrocyanide solution. In the presence of ferric salts an intense blue color is formed.

In order to stain the higher forms of iron bacteria it is well to remove the deposit of iron by treating with a 5 per cent hydrochloric acid solution.

\section{CELLULOSE-DECOMPOSING BACTERIA}

\section{Exercise 54}

Anzrobic Cellulose Decomposition in Impure Cultures

Fill four large test tubes or wide-mouthed deep-form bottles about three-fourths full of Omeliansky's solution (Medium 85).

Add four strips of filter paper to each.

Treat as follows: (1) uninoculated, (2) stable manure, (3) leaf mold, (4) garden soil.

Incubate at $28^{\circ} \mathrm{C}$.

Examine the cultures at regular intervals, taking note of the change in color and the structure of the filter paper.

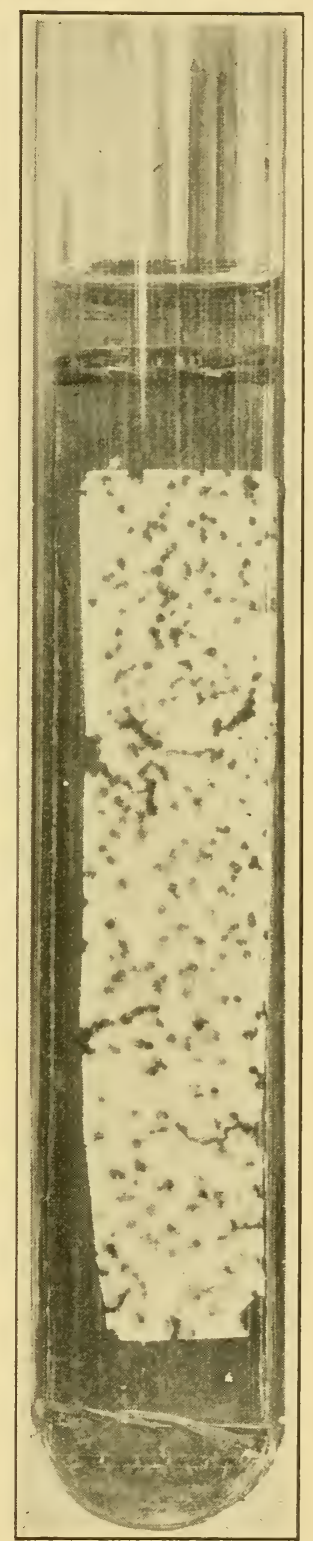

Fig. 16.-Fermentation of filter paper in Omeliansky's solution. 
When the filter paper shows evidences of disintegration, make transfers to new tubes of Omeliansky's medium (enrichment cultures).

\section{Exercise $\mathbf{5 5}$}

Number of Aerobic Cellulose-decomposing Bacteria in Soll ${ }^{1}$

Prepare a series of medium-sized test tubes containing 5 cubic centimeters of Medium 85 (the $\mathrm{CaCO}_{3}$ may be left out and a

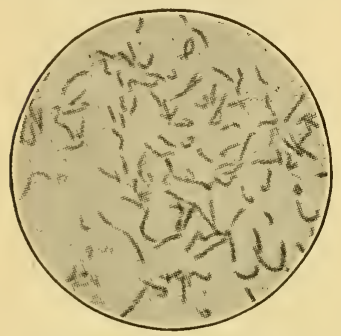

Fig. 17.-Spirochaeta cytophaga. (Hutchinson and Clayton.) trace of $\mathrm{FeSO}_{4}$ introduced) and a strip of paper. Part of the paper should protrude above the surface of medium.

Prepare a series of soil dilutions (1:10, $1: 100,1: 1,000)$ and inoculate 1 cubic centimeter of each dilution into one tube of medium.

Take out, with a sterile pipette, 1 cubic centimeter from the tube inoculated with 1:1,000 dilution and add to a fresh tube of sterile medium, to give a dilution of $1: 5,000$.

If further dilutions are desired the last step is repeated.

The tubes are incubated at 25 to $30^{\circ} \mathrm{C}$. and examined daily. Presence of cellulose-decomposing bacteria will be shown by the decomposition of the paper just at the surface of the liquid.

Examine bacteria by Nigrosin method.

\section{Exercise 56}

\section{Themophilic Fermentation of Cellulose}

Prepare four long tubes (about 25 centimeters each) with 20 cubic centimeters each of the Cellulose peptone medium (Medium 89).

Treat as follows:

(a) Control-not inoculated.

(b) About 1 gram of fresh horse manure.

(c) About 1 gram of well-rotted leaf mold.

(d) About 1 cubic centimeter of a culture of Clostridium thermocellum.

${ }^{1}$ Duвos, R. J., J. Bact., 15 : 223, 1928. 
Cover the tubes with tinfoil and incubate at 60 to $65^{\circ} \mathrm{C}$.

As soon as the cultures show active fermentation make 1 cubic centimeter transfers to tubes of fresh media. This enrichment process may be repeated several times.

Examine young and old cultures under the microscope.

\section{Exercise 57}

\section{Isolation of Cellulose Decomposing Bacteria}

Select samples of soil from plots which have received applications of straw or materials rich in cellulose. From these samples prepare dilutions of about $1: 10,000$ and $1: 100,000$. Instead of soil, enrichment cultures may be used (see Ex. 54, 55). If

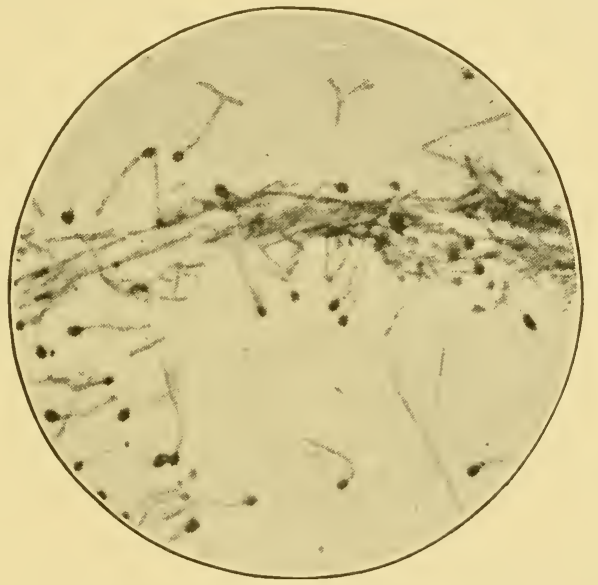

FIg. 18.-Bacillus cellulosae dissolvens attacking filter paper. (Khouvine.)

enrichment cultures are used the dilutions should be greater than those from soil.

Pour plates of the dilutions from soil or enrichment cultures with the cellulose agar medium (Medium 88).

Because of the long period of incubation, 2 to 4 weeks, it is desirable to keep the plates in a moist chamber, under bell jar at $28^{\circ} \mathrm{C}$. At regular intervals, 5, 10, 20, and 30 days, examine the plates. Note change in color and clear zones throughout the opaque agar.

Make microscopic mounts-nigrosin and carbol fuchsin. 
Silica gel containing macerated cellulose on surface may also be used for the isolation of cellulose-decomposing bacteria.

\section{Exercise 58}

The Evolution of Carbon Dioxide from Soll

Weigh out 100 grams of well mixed soil into 500-cubic centimeter Erlenmeyer flasks or other suitable vessels. Arrange as follows:

1. Control, soil alone. No treatment.

2. Soil plus 1 per cent of glucose, starch, cellulose, alfalfa meal, blood meal or similar substances in the powdered form.

Bring the moisture content of the soil to two-thirds saturation.

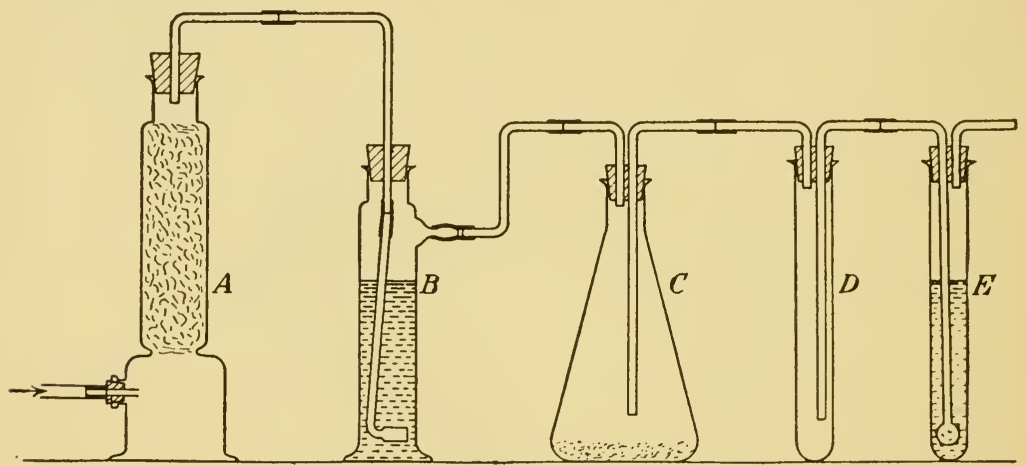

Frg. 19.-Apparatus for measuring carbon dioxide evolution from soil.

After the test substance is well mixed with the soil set up the apparatus in such a way that the $\mathrm{CO}_{2}$ evolved will be absorbed in 25 cubic centimeters of $0.2 \mathrm{~N} \mathrm{Ba}(\mathrm{OH})_{2}$ solution in a large test tube. The large tower $A$ of Fig. 19 is filled with soda-lime and connected to $B$ with a glass tube. The end of this tube carries a gas washing tube. $B$ is filled about two-thirds full of water and connected to $C$. In this way moist $\mathrm{CO}_{2}$ free air is carried to $C$. In flask $C$ is the soil sample. $E$ is a test tube containing the $\mathrm{Ba}(\mathrm{OH})_{2}$ solution. The gas is dispersed into fine bubbles by means of a Rose end tube. $D$ is a trap to catch the alkali solution in $E$ if there is any back pressure, and the alkali in $E$ sucks back. As soon as possible, after the soil is mixed with the various substances, begin a slow aeration at the rate of one 
bubble per second. Every 24 hours, titrate the $\mathrm{Ba}(\mathrm{OH})_{2}$ solution to the phenolphthalein end-point with $0.1 \mathrm{~N}$ oxalic acid (6.3 grams per liter). Continue the absorption from day to day until the $\mathrm{CO}_{2}$ evolution declines to nearly a constant amount.

Barium hydroxide reacts with $\mathrm{CO}_{2}$ according to the following equation:

$$
\mathrm{Ba}(\mathrm{OH})_{2}+\mathrm{CO}_{2}=\mathrm{BaCO}_{3}+\mathrm{H}_{2} \mathrm{O} . \quad 0.1 N \quad \mathrm{Ba}(\mathrm{OH})_{2}=0.1 N
$$
$\mathrm{CO}_{2}=2.2$ milligrams.

The excess $\mathrm{Ba}(\mathrm{OH})_{2}$ is titrated with oxalic acid. The acid neutralizes only the $\mathrm{Ba}(\mathrm{OH})_{2} . \quad \mathrm{Ba}(\mathrm{OH})_{2}+(\mathrm{COOH})_{2}=\mathrm{Ba}$ $(\mathrm{COO})_{2}+2 \mathrm{H}_{2} \mathrm{O}$.

The $\mathrm{BaCO}_{3}$ remains unchanged. The difference between the excess of $\mathrm{Ba}(\mathrm{OH})_{2}$, as determined by oxalic acid titration, and the $\mathrm{Ba}(\mathrm{OH})_{2}$ taken at the beginning, will give the amount of $\mathrm{Ba}(\mathrm{OH})_{2}$ acted upon by the $\mathrm{CO}_{2}$.

An example of the calculation follows:

$\mathrm{Ba}(\mathrm{OH})_{2}, 0.1 N$, factor $1.06 \ldots \ldots 50$ cubic centimeters Oxalic acid, $0.1 N \ldots \ldots \ldots \ldots \ldots 12.6$ cubic centimeters $50 \times 1.06 \ldots \ldots \ldots \ldots \ldots \ldots . \ldots \ldots$ cubic centimeters $0.1 \mathrm{~N}$ Back titration (oxalic) ........ 12.6

$\mathrm{CO}_{2}$ evolved............. 40.4 cubic centimeters $0.1 N$ Since 1 cubic centimeter $0.1 \mathrm{~N}$

$\mathrm{Ba}(\mathrm{OH})_{2}$ takes up......... 0.0022 gram $\mathrm{CO}_{2}$ $40.4 \times .0022 \ldots \ldots \ldots \ldots \ldots \ldots .0 .0889$ gram $\mathrm{CO}_{2}$ per 100 grams of soil.

When the $\mathrm{CO}_{2}$ evolution has declined to nearly a constant amount, plot a curve showing the rate of evolution of the gas. Plot milligrams of $\mathrm{CO}_{2}$ as ordinates, and days as abscissae.

\section{LITERATURE}

The following list includes some of the more important books that treat of bacteriology:

A. General Bacteriology:

Benecke, W.: "Bau und Leben der Bakterien," 2d Ed., Leipzig, 1924.

Buchanan, E. D. and R. E. Buchanan: "Bacteriology for Students in General and Household Science," rev. Ed. 560 pp., 360 figs., New York, 1926.

Buchanan, R. E., and Fulmer, E. I.: "Physiology and Biochemistry of Bacteria," 516 pp., Baltimore, 1928. 
Conn, H. J. and W. H. Conn: "Bacteriology," 3d Ed., Baltimore, 1926. Ford, W. W.: "Textbook of Bacteriology," 1,069 pp., Philadelphia, 1927. Greaves, J. E.: "Elementary Bacteriology," 506 pp., 129 ills. Philadelphia, 1928.

Jordan, E. O.: "General Bacteriology," 9th Ed., 778 pp., 191 ills., Philadelphia, 1928.

Jordan, E. O. and I. S. FALK: "The Newer Knowledge of Bacteriology and Immunology," 1,196 pp., Chicago, 1928.

Kelser, R. A.: "Manual of Veterinary Bacteriology," 525 pp., Baltimore, 1927.

Kendall, A. I.: "Bacteriology, General, Pathological and Intestinal," 2d Ed., 680 pp., Philadelphia, 1921.

Kruse, W.: "Allgemeine Mikrobiologie," 1184 pp., Leipzig, 1910.

Lieske, R.: "Allgemeine Bakterienkunde," 338 pp., 118 figs., Berlin, 1926.

Park, W. H., A. W. Williams, and C. Krumwiede: "Pathogenic Microorganisms," 8th Ed., 811 pp., 211 figs., 9 plates, Philadelphia, 1924.

Rippel, A.: "Vorlesungen über Theoretische Mikrobiologie," 171 pp., Berlin, 1927.

Zinsser, H. and S. S. Tyzzer: "A Textbook of Bacteriology," 1,193 pp. 6th Ed., New York, 1927.

B. Agricultural Bacteriology:

Funrmann, F.: "Einführung in die Grundlagen der technischen Mykologie," 2d Ed., 554 pp., Jena, 1926.

Greaves, J. E.: "Agricultural Bacteriology," Philadelphia, 437 pp. 1922.

Greaves, J. E. and E. O. Greaves: "Bacteria in Relation to Soil Fertility," 239 pp., New York, 1925.

Kayser, E.: "Microbiologie Agricole," 4th Ed., 1921.

Löhnis, F. and E. B. Fred: "Agricultural Bacteriology," 283 pp., 66 figs., New York, 1923.

Marshall, C. E.: "Microbiology," 3d Ed. 1,043 pp., 200 ills., Philadelphia, 1922.

Russell, E. J., et al. " "The Microorganisms of the Soil," 188 pp., 23 figs., London, 1923.

Russell, H. L. and E. G. Hastings: "Agricultural Bacteriology," 368 pp., 63 figs., New York, 1921.

Waksman, S. A.: "Principles of Soil Microbiology," 897 pp., 77 figs., 19 plates, Baltimore, 1927.

C. Reference Books in Bacteriology:

Henneberg, W.: "Handbuch der Gärungsbakteriologie," Bd. 1 and 2, Berlin, 1926.

DE Rossi, G.: "Microbiologia Agraria e Tecnica," 1410 pp., Torino, 1921-1927.

Lafar, F.: "Handbuch der technischen Mykologie," Bd. 3, 503 pp., 10 plates, 90 figs., Jena, 1904-1907.

LöHNis, F.: "Handbuch der landwirtschaftlichen Bakteriologie," Berlin, 907 pp., 1910.

Sмrтн, E. F.: "Bacteria in Relation to Plant Diseases," Vols. 1, 1905; 2, $1911 ; 3,1914$, Washington. 
Stoklasa, J. and E. G. Doerell: "Handbuch der biophysikalischen und biochemischen Durchforschung des Bodens," 812 pp., Berlin, 1926.

D. Manuals of Bacteriologic Technic:

ABEL, R.: "Bakteriologisches Taschenbuch," 1927.

American Public Health Association: "Standard Methods for the Examination of Water and Sewage," 6th Ed., New York, 1925.

Conn, H. J.: "An Elementary Laboratory Guide in General Bacteriology," 98 pp., 27 figs., Baltimore, 1927.

Cunningham, A.: "Practical Bacteriology," 188 pp., London, 1924.

Giltner, Ward: "Laboratory Manual in General Microbiology," 3d Ed., 472 pp., New York, 1926.

Hastings, E. G. and W. H. Wright: "A Laboratory Manual of General Agricultural Bacteriology,” 83 pp., 28 figs., Madison, 1927.

Levine, M.: "Laboratory Technique in Bacteriology," 149 pp., New York, 1927.

Norton, J. F. and I. S. FALK: "Laboratory Outlines in Bacteriology and Immunology," 114 pp., Chicago, 1926.

Koch, A.: "Mikrobiologisches Praktikum," 109 pp., 4 figs., Berlin, 1922.

KÜster, E.: "Kultur der Mikroorganismen," 3d Ed., Leipzig, 1921.

Löнnis, F.: "Landwirtschaftlich-bakteriologisches Praktikum," 3d Ed., Berlin, 1926.

Muir, R. and J. Ritchie: "Manual of Bacteriology," 7th Ed.; 753 pp., London, 1921.

E. Classification of Bacteria:

Bergey, D. H.: "Manual of Determinative Bacteriology," 2nd Ed., Baltimore, 442 pp., 1925.

Buchanan, R. E.: "General Systematic Bacteriology," 597 pp., Baltimore, 1925.

Lehmann, K. B. and R. O. Neumann: "Bakteriologie, insbesondere bakteriologische Diagnostik.," I Band, "Technik, Allgemeine Diagnostik, Atlas," 172 pp., 65 plates. München, 1926; II Band: "Allgemeine und spezielle Bakteriologie," 876 pp., 43 figs., München, 1927.

\section{LIST OF LABORATORIES WHERE CULTURES MAY BE SECURED}

1. American Type Culture Collection, George H. Weaver, Curator, 637 South Wood Street, Chicago, Illinois.

2. The Lister Institute of Preventive Medicine, National Collection of Type Cultures, Chelsea Gardens, London, S. W., England.

3. Professor Dr. E. Pribram's mikrobiologische Sammlung, vorm. Kral's bakteriolog. Museum, Wien, IX/2. Michelbeuerngasse Ia, (Wien) Vienna, Austria. 
4. Centraalbureau voor Schimmelcultures, Professor J. Westerdijk, Baarn, Holland.

5. Professor Alfred Jörgensen, Laboratory of Fermentology, Copenhagen, Denmark.

6. Professor Dr. E. de Hérics-Tóth, Roy. Hungarian Institut of Fermentology, Budapest II. Debröi u. 15. Hungary.

7. L'Institut Pasteur, Director, Dr. E. Roux, Institut de Microbiologie, 25 Rue Dutot, Paris 15, France. 


\section{INDEX}

A

Acid, resistant finish for tables, 91 sucrose agar, 13

Actinomyces, media for, 18

Aeration method for ammonia determination, 63

Agar, chemical composition, 5 general properties, 5 washed, 5

Albuminate agar, 9

Algæ, culture media for, 20

in soil, 93

number in soil, 97

Alizarine, 52

Amino acids, decomposition of, 138 nitrogen, 69

Ammonia, determination in soil, 127 quantitative, 62

production, 127

test for, 56

Anaerobic bacteria, 11, 43

culture media, 11

number in soil, 100

cellulose fermentation, 133

culture methods, 46

nitrogen fixation, 118

Analysis of plant material, complete, 76

Apparatus for one student, 89

Artificial cultures, 110

Ashby's medium, 20

Asparagin, mannitol agar, 11 sodium lactate gelatin, 27 starch agar, 14

Autotrophic bacteria, 2

Azotobacter colonies, 115

grow th on different carbohydrates, 117
Azotobacter colonies, in soil, 114 isolation of, 114 nitrogen fixation by, 116

B

Bacillus cellulosæ dissolvens, 135 cereus, 128

Bacteria in soil, 92

number in soil, plate method, 99

Bacterium fluorescens, 128

hartlebii, 122

pyocyaneum, 122

radiobacter, 116

Bacteroid formation, 34

Barium hydroxide solution standard, 56

Barlow stain, 51, 109

Bean extract, 34

Beef extract agar, 8

Beef extract gelatin, 8

Black finish for tables, 91

Bouillon, 8

Brain, sheep or beef, 43

Bristol's medium for algæ, 21

Brom cresol purple milk, 39

Brucine reagent, 59

Bryan's medium, 45

Burri's Pelikan Tusche, 49

\section{C}

Caffein bean extract, 34

Calcium hypochlorite, seed sterilization, 83

Capsule stain, 49

Carbohydrates, determination of, 69-76

Carbohydrates, effect on nitrogen fixation, 120 
Carbol fuchsin, 47

thionin (Nicolle's), 48

Carbon dioxide, determination of, 79,80

from soil, 136

total, 80

Carrot extract agar, 33

agar for yeast, 18

Casein hydrolysis, 42

Caseinate agar, 9

Cellulose agar, 37

bacteria, media for, 35

determination of, 69

decomposing bacteria, isolation of, 135

thermophilic, 134

decomposition

aerobic, 134

Characteristics of root nodule bacteria, 108

of soil population, 92

Chemosynthetic bacteria, 2

Cleaning solution, 90

Clostridium pasteurianum, 101, 114, 118

Clostridium thermocellum, 134

Clover sucrose agar, 15

Cochineal, 52

Color change of indicators, 53

Congo red, method for examining bacteria, 96 negative stain, 51

Corn meal medium, 43

Crone's medium, 45

Crystal violet, ammonium oxalate, 48

Culture media, 1

Czapek's solution, 13

D

Davisson-Parsons method for nitrogen determination, 68

Denitrification by pure cultures, 121 in soil, 122

Denitrifying bacteria, isolation of, 121

media for, 25
Depth, effect on number, 102

Detmer's solution for algæ, 20

Diphenylamine reagent, 59

Direct method of measuring number of bacteria, 104

Directions for media, 3

Dorner capsule stain, 49

spore stain, 50

of nitrogen fixing, bacteria, 119

$\mathrm{E}$

Embedding nodules, 111

Enrichment media, 1

Erythrosin, 49

method of staining soil bacteria, 51

Ethyl alcohol solution, 25

Exercises in soil microbiology, 87

F

Fat decomposition, 41

Ferric ammonium citrate, 43

Ferrous carbonate medium, 32

Filtration of culture media, 4

Flemming's stain, 112

Frazier's gelatin, 42

Fungi, culture media, 12 in soil, 93,98

G

Gelatin, chemical composition, 5 general properties, 5

liquefaction, 42

Gelidium corneum, 5

Giltay's medium, 25

Glucose phosphate, nitrogen-free, 11

Glycerol agar, 129

Gram stain, 48

Green plants, culture media, 44

Gum formation, 35

$\mathrm{H}$

Hanging-drop preparations, 95

Hansen's solution, 16

Hay infusion for protozoa, 19 
Hayduck's medium, 18

Heidenhains hæmatoxylin, 112

Heterotrophic bacteria, 2

Heyden agar, 9

Humus, determination of, 78

Hydrogen bacteria, medium for, 30 sulphide bacteria, 139

Bavendamm, 30

Hydroxylamine, test for, 58

\section{I}

\section{Indicators, 53}

Indol, test for, 61

Ink method, capsule stain, 49

Insects, number in soil, 105

Invertebrate population of soil, 94

Iron bacteria, 133 oxidizing bacteria, media for, 31 precipitating bacteria, 132

Isolation of anaerobic bacteria, 118

\section{K}

\section{Koch, 1}

Koser's medium for colon-ærogenes group, 43

Krainsky's medium, 13

L

Laboratories, supplying cultures, 139

Laboratory rules, 89

Lagerberg's spore stain, 50

Leguminous plants, bacteria of, 106

Lignins, 75

Literature, 137

Litmus, 52 milk, 39

Loeffler's alkaline methylene blue, 47 Lugol's iodine, 48

\section{M}

Malt extract agar, 16

Manganese, oxidizing bacteria, media for, 31
Mannitol, nitrogen free, 32 phosphate solution, 20 soil extract, 20

Manure, effect on number of microorgamisms, 103

Media, 1

Mercuric chloride, disinfectant solution, 90 seed sterilization, 82

Methane bacteria, medium for, 31

Methods of staining, 47

Methyl orange, 52 red, 67

Methylene blue as indicator of anaerobiosis, 46

Microscopic examination of soil, 104, 105

Milk, culture media, 39 brom cresol purple, 39

Moisture determination, 61

$\mathrm{N}$

Nährstoff-Heyden agar, 9

Negative stain, 109

Nematodes, number in soil, 103

Nessler's reagent, 56

Nesslerization of ammonia, 62

Nigrosin negative stäin, 50

Nitrate formation, 123 reducing bacteria, media for, 25

Nitrates and nitrogen fixation, 120 determination of (reduction), 65 quantitative determination of, 63 reagent, 57,59

Nitrification in liquid cultures, 123 , 124

of various substances, 125

Nitrifying bacteria, enrichment cultures, 123 media for, 22

Nitrite formation, 123

Nitrites, test for, 57

Nitrobacter, 125

solution for, 23 
Nitrogen, determination of, 65

fixation in soil, 119

fixing capacity of soil

Winogradsky's method, 119

fixation by cultures of Azotobacter, 116

bacteria, media for, 32

Nodule bacteria, isolation of, 106

and nitrogen content of plants, 113

in agar, 109

Normal sodium hydroxide, 55

sulphuric acid, 54

Nutrient agar, 8

broth, 8

gelatin, 8

Nutrition of bacteria, 1

Nutrose agar, 9

$\mathrm{O}$

Oxalic acid, standard, 55

Oxidation of ammonia, 23

sulphur, 131

$\mathrm{P}$

Paraffin agar, 41

Pasteur, 1

Pea extract, 34

Pentosans, 70

Peptone malt agar, 15

mannitol solution, 12

sucrose, 35

Phenoldisulphonic acid, 60

Phenolphthalein, 52

Physiological groups, 104

Plant material, analysis of, 76

Potassium nitrate, thiosulphate solution, 26

Potato culture media or potato slants, 39

glucose agar, 14

Preparation of $\mathrm{H}$ ion indicators, 53

Preservation of stock cultures, 45

Preserving plates, 45

plate cultures, 46

Pressure and temperature, 7

Protein decomposition, 128
Protozoa, 94

media for, 19

number in soil, 98

Pyrogallic acid for absorbing oxygen, 46

\section{$\mathrm{R}$}

Raisin extract, 17

Raulin's solution, 12

Reaction, 3

Reagents, 52

Reducing sugars, 72

Reduction of sulphates, 26

Rock phosphate, 131

Root, effect on number of bacteria, 102

nodule bacteria, isolation, 107 structure of, 111

Rose bengal, 96

\section{S}

Safranin, 48

Schweitzer's reagent, 69

Season, effect on number, 102

Sectioning nodules, 111

Seed sterilization, 82

Selective media, 1

Shaffer and Hartman modified, 72

Silica gel, general properties, 5 preparation of, 6

Souleyre, 35

use of, 116

Silicic acid gel for nitrite forming bacteria, 24

Size of organisms in soil, 94

Sodium albuminate agar, 9

asparaginate, glycerol agar, 19 caseinate agar, 9

citrate (Koser), 43

Soil extract agar, 10

gelatin, 10

stock solution, 10

population, 92

samples, how taken, 97

Sorenson's phosphate $\left(\mathrm{Na}_{2} \mathrm{HPO}_{4}\right.$-$2 \mathrm{H}_{2} \mathrm{O}$ ), 40

Souleyre, silica gel, 35 
Spirochaeta cytophaga, 134

Spore-forming bacteria, determination of, 101

stain, 50

yeast medium, 18

Staining of bacteria, 47

Starches, 71

Sterilization of media, 6 of soil, 7

Straw, effect of on numbers of microorganisms, 103

Structure of the root nodule, 111

Suction filter, 4

Sulphates, reduction of, 128

Sulphur bacteria, 130

high forms, 130 oxidizing bacteria, media for, 28

Sulphuric acid, normal solution, 54

\section{$\mathrm{T}$}

Tap-water gelatin, 11

Temperature and pressure, 7

Test for ammonia, 56

for ferric iron, 133

for hydroxylamine, 58

for indol, 61

for nitrates, 58

for nitrites, 57

Thermophilic bacteria, 38, 101, 134

Thiobacillus thioparus, 131

thiooxidans, 132

Thionin, 48

Thiosulphate solution, 28

Thomas' test reagents, 57

Thornton's medium, 11

Total carbon, determination of, 80 nitrogen (Davisson-Parsons), 68 (Kjeldahl), 65 to include nitrates, 67
Transferring cultures, 90

Trommsdorf reagent, 57

Tubeuf's medium, 15

Truffaut and Bezssonoff medium, 12

U

Urea bacteria, isolation of, 127

media for, 21

citrate solution, 21

decomposition, 136

soil extract solution, 22

V

Vegetable tissue for absorbing oxygen, 46

W

Worms, number in soil, 105

Washed agar for nitrifying bacteria, 23

Water-holding capacity of soil, 61

Winogradsky's direct count, 105

glucose-peptone agar, 12

medium, 11

solution for Nitrosomonas, 22

\section{$\mathrm{Y}$}

Yeasts and yeast spores, 96

infusion (dried), 17

infusion (fresh), 16

media for, 16

water sulphite agar, 27

\section{$\mathrm{Z}$}

Ziehl's carbol fuchsin, 47 






